Entre os

destrogeos do

presente

Quatro entrevistas sobre

o novo tempo brasileiro do mundo

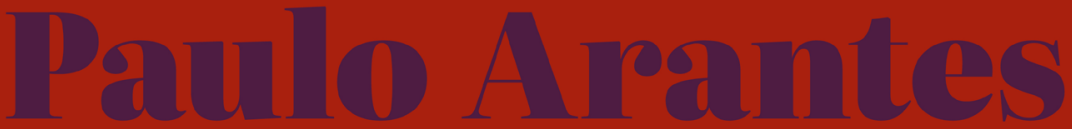




\section{Entre os destroços do presente}

Quatro entrevistas sobre o novo tempo brasileiro do mundo 
Categorias: Filosofia; Política; Estética; Arquitetura e Cidades; Artes Plásticas; Crítica da Cultura e Trajetórias. Cada categoria adota uma cor específica aplicada na capa do e-book.

\section{Subcoleções:}

E-books: livros, capítulos, prefácios, artigos e entrevistas (em formatos PDF, EPUB e MOBI/Kindle) - com obras em português, inglês, espanhol, italiano e francês.

Documentos: matérias de jornal, fotos e documentos históricos (em formatos

PDF e JPEG)

Mídia: vídeos ou áudios de palestras, aulas e debates (em formatos MP3 e MP4) associados a um canal da coleção no YouTube.

Coordenação editorial: Pedro Fiori Arantes

Projeto Gráfico: Paula Astiz

DADOS INTERNACIONAIS DE CATALOGAÇÃO NA PUBLICAÇÃO (CIP) (CÂMARA BRASILEIRA DO LIVRO, SP, BRASIL)

\section{Arantes, Paulo Eduardo, 1942-}

Entre os destroços do presente [recurso eletrônico] : quatro

entrevistas sobre o novo tempo brasileiro do mundo (2014-2015) /

Paulo Eduardo Arantes. -- São Paulo : [s.n], 2021.

ePUB. - (Coleção sentimento da dialética / coordenação Pedro

Fiori Arantes)

ISBN 978-65-00-31186-0

1. 1. Brasil - Política e governo - 2011-2016. 2. Movimentos de

protesto - História - Séc. XXI - Brasil. 3. Manifestações públicas

- História - Séc. XXI - Brasil. 4. Conflito social - Brasil. I. Arantes,

Pedro Fiori, 1974-. II. Título. III. Série,

CDD 303.620981

Elaborado por Cristiane de Melo Shirayama - CRB 8/7610

DOI: https://doi.org/10.34024/9786500311860

\section{(c) (1) $(\Theta$}

Esta obra tem licença Creative Commons internacional 4.0

http://creativecommons.org/licenses/by-nc-nd/4.0/

Publicado originalmente em:

A entrevista "Entre os destroços do presente" foi publicada parcialmente na

Revista Caros Amigos n.215, de fevereiro de 2015, com o título "O capitalismo está

morrendo de overdose" e na íntegra no Blog da Boitempo, complementada por um postscriptum.

A entrevista "Sinal de menos" foi publicada na Revista Sinal de Menos n.11, vol. 2, 2015 A entrevista "No tempo das emergências" foi publicada no jornal Valor Econômico, em 9 de abril de 2014.

A entrevista "Exaustão" foi publicada no jornal Correio da Cidadania, em 17 de julho de 2015 , sob o título de "A fórmula mágica da paz social se esgotou".

\section{Sentimento da Dialética}

UM ENCONTRO COM A OBRA DE OTÍLIA E PAULO ARANTES
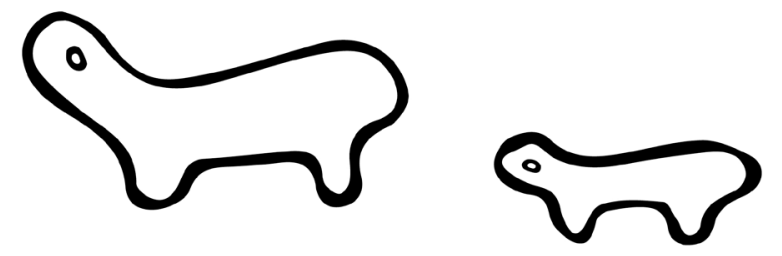

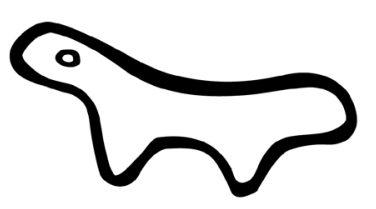




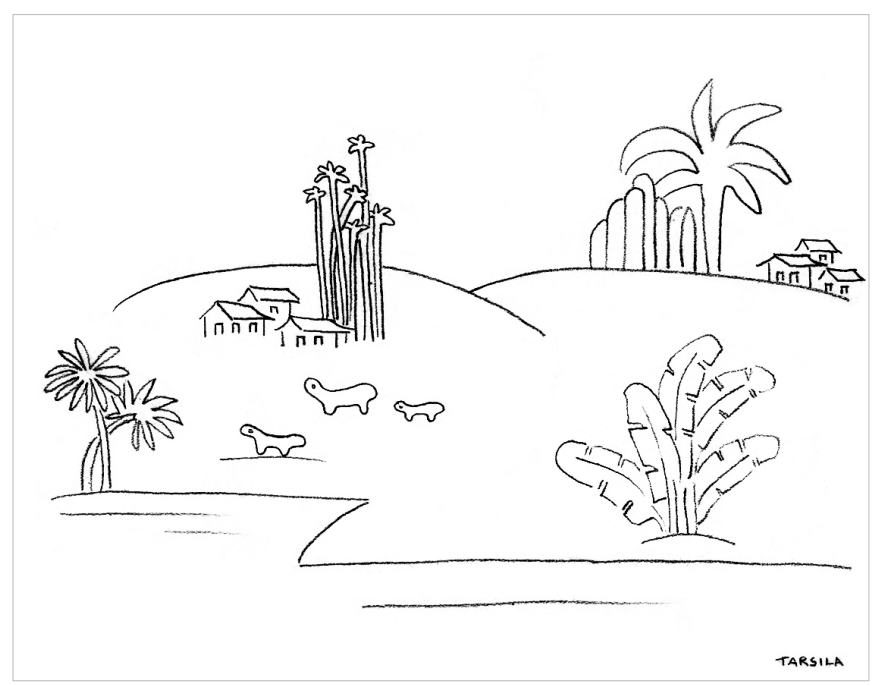

Tarsila do Amaral. Paisagem antropofágica - I, 1929 c - lápis s/ papel, 18,0 x 22,9 cm. Coleção Mário de Andrade. Coleção de Artes Visuais do Instituto de Estudos Brasileiros USP. Reprodução gentilmente cedida pela família e IEB USP.

O novo tempo do mundo exige dos intelectuais responsabilidades que lhes são intrínsecas: a de tornar a força das ideias parte do movimento de entendimento e transformação do mundo. Os filósofos Otília Beatriz Fiori Arantes e Paulo Eduardo Arantes cumprem, juntos, há mais de 50 anos, a tarefa da crítica como intelectuais públicos atuantes, transitando entre diversas áreas das humanidades e da cultura, em diferentes audiências e espaços de formação. A coleção Sentimento da Dialética é um lugar de encontro com a obra de Otília e Paulo Arantes e reafirma o sentido coletivo da sua produção intelectual, reunida e editada em livros digitais gratuitos. É um encontro da sua obra com um público cada vez mais amplo, plural e popular, formado por estudantes e novos intelectuais e ativistas brasileiros. É também um encontro da sua obra com o movimento contemporâneo em defesa do conhecimento livre e desmercantilizado, na produção do comum e de um outro mundo possível. 

SINAL DE MENOS NO TEMPO DAS EMERGÊNCIAS EXAUSTÃo 


\section{ENTRE OS DESTROÇOS DO PRESENTE*}

O senhor é um dos fundadores do PSOL...

Sim, assinei a ata de fundação. Estava em boa companhia, Chico de Oliveira, Carlos Nelson Coutinho, Ricardo Antunes e tantos outros igualmente escandalizados com a reviravolta petista, que acabara de beijar a cruz. E uma vez de joelhos, teria de rezar. Descrevi este ritual num artigo para a revista Reportagem, em abril de 2003. Não se tratava apenas de escolhas macroeconômicas reversíveis, mas de toda uma virada de época. Sem volta, como a presidente Dilma está comprovando agora, beijando a cruz uma segunda vez, para desconsolo de André Singer, que registrou a repetição (Tragédia? Farsa? Nenhuma das duas?) em sua coluna na Folha. A vantagem de Lula em 2018 é que se reapresentará com a dita-cuja beijada duas vezes. Se voltar a chover na horta das commodities será “o

* Esta "entrevista" foi precedida por uma longa conversa de Paulo Arantes com Aray Nabuco e Lilian Primi, em meados de outubro, de cuja transcrição extraíram as perguntas que foram respondidas por escrito em fins de dezembro de 2014, início de janeiro deste ano. O resultado foi publicado parcialmente na Caros Amigos n.215, de fevereiro de 2015, com o título "O capitalismo está morrendo de overdose". A versão integral do texto de que o leitor agora dispõe foi enviada diretamente pelo autor ao Blog da Boitempo complementada por um postscriptum redigido na primeira semana de abril intitulado "O nome da crise", sobre os "idos de março". 
cara" novamente. Mas com a mudança climática em curso, daqui pra frente chuva e seca serão sobretudo eventos extremos. E não vai dar pra mandar a conta para a reação conservadora de turno.

\section{Como viu a campanha para presidente?}

O mesmo circo fetichista de sempre, só que pior a cada edição. Todo mundo sabe que naquela engrenagem nada mais é para valer, que todos aqueles rituais estão vazios, e no entanto entram em cena e atuam como se não soubessem. Refiro-me à esquerda, é claro. A direita sempre soube disso, é agnóstica e materialista em matéria de religião política.

\section{E o desempenho de Luciana Genro?}

Saiu melhor do que a encomenda. Defendeu com brio e galhardia seu papel de grilo falante esquerdista, como o Plínio na última presidencial. Não digo isso para desmerecer, é o que restou, e não é pouco: fazer-se de desentendido em pleno picadeiro é uma arte. Tiradas à parte, o fato é que tanto a candidata quanto o PSOL souberam como crescer na pauta dos valores de sociedade, a agenda da vez. Por não precisarem pagar o mico de ser governo, podiam se dar ao luxo do inegociável, e nisso desafiar a intransigência da nova direita.

\section{Votou nela?}

Não, não votei. Mas avisei com bastante antecedência, aliás num seminário promovido pelo PSOL em fevereiro de 2014. Pedir votos depois de Junho, nem pensar. Num dos primeiros balanços daquela onda de protestos, um jornalista não se acanhou em descrevê-los nos mesmos termos em que Lênin caracterizava uma situação revolucionária: nem o povo aceita mais ser governado como vinha sendo, nem os dominantes conseguem fazê-lo de outro modo. Junho apenas deu a medida descomunal do desencontro. É preciso acrescentar que não voto para cargo executivo desde 2002, e mesmo assim não foi lá muito convicto aquele voto, no entanto ainda valia a pena testar uma mudança da guarda no alto comando. De fato mudou, mas numa direção que ninguém previa. Não vou dizer que é fácil anular o voto, que seja uma coisa que se faça de consciência leve, pois ainda pesa nossa longa memória eleitoral, o sentimento atávico de faltar com algum dever de solidariedade social, sensação além do mais embaçada pelo fato de que desta vez havia voto popular dos dois lados, de modo que imaginar barrar a escalada da direita votando em políticos e governos, francamente. Além do mais, governos governam e ponto. Esquerda e direita encomendarão os mesmos submarinos, uns mais, outros menos zelosos na gestão de nosso entorno estratégico, como se diz. Assim sendo, nunca me passou pela cabeça aconselhar o voto nulo, ou simplesmente não votar, porque o governo da vez não é suficientemente de esquerda. Não estou imune, mas bobagem desse porte acho que não.

\section{O senhor milita para o partido?}

Não, minha contribuição restringiu-se ao mencionado ato de fundação. Acontece que tinha sido testemunha de defesa no processo de expulsão dos três dissidentes (Heloisa Helena, Luciana e Babá). Quando se cogitou a funda- 
ção de um novo partido, pensei com meus botões que já não era mais o caso, o fiasco do PT deixara todo mundo escaldado. Mesmo assim topei, era o mínimo a fazer no momento. E ponto. Sempre que sou chamado a falar, digo o que penso num ambiente de grande camaradagem, mas é só, nenhum palpite em questões internas, aliás nem me pedem, era só o que faltava.

Sei que anda desgostoso com a política institucional. Poderia nos explicar seus motivos?

Nem gosto, nem desgosto. Acabou, pura e simplesmente, essa tal de política institucional, que aliás nunca fiz nem tentei, não levo jeito. Mas sempre admirei quem fazia, esse o ponto. Sendo de esquerda, torcia à distância por meus correligionários que aceitavam carregar aquele piano, no fundo, nada mais nada menos do que o fantasma da construção nacional. Agora que a expressão escapou, preciso me explicar. Na Faculdade em que me formei, e na qual continuo mais ou menos "ativo" há exatos cinquenta anos, pairava no ar uma atmosfera intelectual e política muito específica, mais conhecida como Tradição Crítica Brasileira, cujo espírito se extinguiu mas ainda pode ser reencontrado em obras clássicas bem conhecidas, no geral nascidas na esteira da Revolução de 30, e consolidadas justamente no momento de cristalização institucional das conquistas do movimento modernista. Sem ser revolucionária, longe disso, uma linhagem cultural frontalmente antioligárquica, até hoje uma posição "radical", numa acepção particular que agora seria excessivo explicar. A escola sociológica paulista nasceu assim. Hoje um dos seus maiores expoentes dá nome ao principal centro de irradiação pedagógica do MST, Escola Nacional Flores- tan Fernandes. Todavia são muito raros entrecruzamentos como este, entre a Tradição Crítica e a Tradição Militante. Talvez esteja aí o foco da pergunta. Seja como for, a tradição militante sempre se descaracterizou sem o confronto com o instituído como horizonte, ao passo que a assim chamada tradição crítica, tão brasileira quanto a jabuticaba, sendo o país aquilo que se sabe, uma procissão de milagres que não se completam, comporta uma certa dimensão construtiva: é preciso que o país estirpe suas raízes patriarcais, elimine a praga do patrimonialismo etc., dimensão afirmativa civilizadora que demanda precisamente instituições bem planejadas nesse espírito de esclarecimento e equidade social. Daí nosso apreço pelas vocações para a responsabilidade, que ela, tradição critica, sempre despertou, e não surpreende que tenha sido alimentada por uma pequena legião de servidores públicos, cuja ascensão eventual a postos de comando, de uma chefia de Departamento à Presidência da República, podia com razão também ser encarada como o arremate dessa tradição empenhada. Portanto, política institucional era um dever encarado com a naturalidade dos que se imaginavam herdeiros do esforço de transformar a ordem colonial em progresso nacional. Ao se encerrar o ciclo das grandes interpretações do Brasil, cujo ponto de fuga invariavelmente apontava para o Estado e suas adjacências, o impulso original do serviço perdurou um momento por inércia, até se dissolver no vazio da política de poder, o mesmo vácuo social que engoliu por sua vez todo o aparato ideológico da tradição militante. Todos batemos no teto ao mesmo tempo, ao se inaugurar no Brasil que emergiu do colapso de sua modernização um outro modo de governar recompondo os cacos da implosão dos cinquenta anos de desenvolvimentismo. E esse novo paradigma é o 
da emergência. É só acompanhar a curva de evolução da chamada "questão social", que se tornou uma questão de segurança, assim como a polícia hoje também "intervém" se apresentando como agente de transformação social. Aquele colapso não foi qualquer, mas uma verdadeira ruptura de época, e se avançarmos na nossa conversa aparentemente eleitoral, veremos que foi por essa brecha que o PT se insinuou, foi sua sorte grande, porém com um prazo de validade que está se esgotando agora. O horizonte do mundo encurtou, e seu tempo passou a ser medido pela urgência da intervenção imediata, de sorte que a política deixou de ser a dimensão essencial de encaminhamento das expectativas humanas para se "institucionalizar" hoje como mera gestão, ainda por cima de caráter preventivo, e no que se refere aos cidadãos de segunda classe, que vivem da mão para a boca, predominantemente de contenção social, acionando de preferência seu braço penal conforme a circunstância, isto é, quase sempre. Posso me explicar melhor por contraste, histórico no caso. Nem sempre foi assim, houve época em que a institucionalização da luta política pareceu oferecer uma saída para as classes perigosas porque laboriosas. Começando pelo Velho Testamento. Da Revolução Francesa até a Comuna de Paris, a causa do povo, como se dizia, foi defendida de crise em crise pela via insurrecional, em resposta ao estado de repressão permanente instituído pelas classes proprietárias. Depois do último massacre em 1871, as barricadas começaram a ser substituídas pela luta política organizada em partidos no território do inimigo, o Parlamento. $\mathrm{Pa}-$ receu funcionar, sobretudo na Alemanha, até 1914. Com a guerra não só toda essa arena implodiu como arrastou consigo os representantes do campo popular, que principiaram votando os créditos de guerra e concluíram a obra comandando a contrarrevolução a partir de novembro de 1918. É que em 17 a via insurrecional havia sido retomada. Não vou continuar, nem mesmo para lembrar que no Brasil algo equivalente ocorreu na Era Vargas, com a "legalização" de porções bem escolhidas da classe trabalhadora urbana, e olhe lá. Meu ponto é outro, a saber: que a assim chamada política institucional, burguesa por definição, de burguesa não tem nada, quem agitava o Parlamento e instituições conexas fazendo a política andar e a sociedade se abrir para os de baixo, era a mão esquerda política das classes populares. Assim como para o capital a produção é um estorvo, uma pedra no caminho entre D e D', para a burguesia a política também é um atrapalho no caminho da dominação direta, desinstitucionalizada ou "mecanizada", como demonstrou na administração por decretos em suas colônias, e mais adiante no interregno, ou melhor, no auge fascista. Toda vez que o poder político institucionalizável da classe trabalhadora foi esvaziado por seus inimigos, toda a política indevidamente chamada de burguesa veio abaixo. Foi o que se viu no entreguerras europeu, o fim da civilização liberal-burguesa. A revelação terminal de sua índole original. Não deu outra com a Restauração Neoliberal a partir dos anos 70/80: a anulação política da classe operária europeia, atingida de morte pela chamada reestruturação produtiva que a pulverizou pelos quatro campos do globo, deixou a burguesia governando o vazio, ou melhor, a multidão dos cidadãos consumidores avulsos de políticas públicas, que podem comprar ou rejeitar em bloco conforme lhes dê na veneta, no geral, tal veneta, um feixe agressivo de conveniências e preconceitos. Agora pensemos um pouco em nosso labirinto, o fim de linha da dita cuja, a política institucional. A irremediável situação calamitosa em que nos encontra- 
mos por um bom tempo nada mais é do que um rastro propriamente burguês que o PT e agregados foram deixando pelo caminho em sua irresistível derrocada. Só neste sentido negativo ele tem alguma responsabilidade no capítulo, justamente a aparência simétrica e invertida de sua imagem pública enxovalhada, triste e imerecido fim pela relevância dos serviços prestados. Voltemos a nosso termo de comparação francês. Antes da capitulação ao longo dos anos Mitterrand, não havia escolha pública substantiva em que a classe trabalhadora, para bem ou para mal, não tivesse voz no capítulo, por vezes com poder de veto. Depois foi o que se viu: sem partidos, sem imprensa, sem intelectuais, sem irradiação nas periferias saídas da imigração, abandonou a cena desmoralizada e ressentida, mas ainda trabalhadora, e como, nas piores condições, onde até procurar emprego também é um trabalho, carregando nos ombros todo o sofrimento do mundo. Novamente, não deu outra. A corrosão acelerada da sociedade salarial francesa deixou sua correspondente política institucional girando no vazio, ocupado por uma elite que sequer acredita na legitimidade de sua própria dominação, exercida sem antagonismos, salvo os amotinados das periferias em perene pé de guerra. É por isso que ao avançar sobre este terreno a um tempo convulsionado e paralisado pela predação vinda de cima, a extrema-direita provoca uma forte impressão de renascimento político, pois o Inimigo está de volta. Portanto, não é só desgosto não, é exercício findo mesmo.

Acabou a esperança, o sonho?

Não sou tão distraído assim para responder de bate e pronto sim ou não. Acabei de publicar um livro de ensaios
[O novo tempo do mundo] em que estas noções nada triviais estão enterradas no subsolo, sem no entanto serem nomeadas uma só vez, salvo numa ou noutra ocasião em que sua menção é claramente anódina. Tendo além do mais resvalado, pelo uso contínuo e indiscriminado, para a vala comum das exortações edificantes, seu uso tornou-se verdadeiramente proibitivo. Além do mais, estes dois conceitos geminados figuram no centro de uma obra prima muito irregular de Ernst Bloch, O princípio esperança, cuja primeira redação data de 1937/38, uma época em que a rigor ninguém esperava mais nada, salvo o pior. De modo que não se pode empregá-los sem tomar posição em relação ao livro. Coisa que Hans Jonas fez em 1979, tratando de rechaçá-lo pelo ridículo, caricaturando-o como um conto de fadas tão irresponsável quanto mortífero. Seja como for, o contraponto assinalava uma ruptura real e não mero bate-boca ideológico. Num lado, o espírito da utopia, de outro o princípio rival, o princípio da precaução, uma espécie de guardião vigiando a porta do futuro em nome da responsabilidade dos contemporâneos em relação às gerações vindouras. Não é preciso dizer qual dos dois "princípios" antagônicos prevaleceu a ponto do inequívoco Presentismo inerente à supremacia da visão "responsabilizadora" - o título original do livro de Hans Jonas é precisamente Princípio responsabilidade - englobar hoje em dia gregos e troianos, apocalípticos e integrados. Assim, tanto insuspeitos ecossocialistas quanto formuladores das estratégias preventivas do que está sendo chamado de Estado de Precaução, procedem segundo uma outra e nova racionalidade política, regida pela percepção de que a sociedade de risco em que passamos a viver é uma máquina geradora de eventos extremos catastróficos. Foi assim com o breve século vinte de Hobs- 
bawm, já está sendo assim com o novíssimo século XXI transcorrendo condenado de antemão pelo aquecimento global. Essa racionalidade presentista que nos move a todos também pode ser interpretada como um Sistema da Dívida. No livro em questão, tentei redescrever tal sistema como um tempo de expectativas decrescentes. E não se trata apenas de mostrar que o futuro já foi consumido pelo endividamento universal que se exprime na supremacia devastadora do capital fictício. Estou me referindo a uma alteração mais profunda e radical na relação entre tempo e política, mas agora voltando a reconhecer na política sua dimensão essencial de foco gerador de expectativas humanas. Dimensão afetada agora pelo sentimento de que a História não é mais o Tribunal do Mundo. A fórmula progressista, a História me absolverá, não faz mais sentido, realejos retóricos à parte. Aquela relação inverteu-se, é a História em pessoa que se encontra agora no banco dos réus, ao invés de redenção, esta velha e sábia senhora só produziu desgraças e voltará a produzí-las se não for "responsabilizada" a tempo. Para frente e para trás, um só presente indefinidamente prolongável e devedor de alguma prestação de contas. O tempo não cura mais nada. Estamos todos nessa ratoeira. É só pôr a mão na consciência quando, por exemplo, falamos em acertar as contas com o passado. Mas como a consciência progressista pesa, logo acrescentamos, sim, mas para finalmente abrir de uma vez as portas do futuro. Mas onde ele está? Na mudança climática? No próximo vírus de última geração? Estou falando é claro do dever de memória e verdade preconizado pela Justiça de Transição. Violações imprescritíveis empurraram para o passado a agenda de justiça e libertação da esquerda. Não acho pouca coisa, nem um simples equívoco ideológico, desde que esta rotação seja compreendida nos seus próprios termos e não seja embalada numa maquiagem futurista qualquer. Prestes podia "perdoar" Vargas para fazer avançar o processo. O similar contemporâneo soaria como sacrilégio. Como deveria parecer demente o discurso da página virada, e o pior é que ninguém nota. Isso não é tudo. Violações que nenhum tempo jurídico prescreverá são dívidas e culpas que exigem igualmente sanções, tanto penais quanto cíveis. Isto é, punição sim, e igualmente reparações materiais. Tremenda reviravolta, diante da qual a esquerda precisa se reinventar, sobretudo agora que o carisma dos direitos humanos se rotinizou e se tornou política pública (sic) dos próprios Estados violadores. Mesmo cenário de responsabilização diante de um tribunal se nos voltarmos para o futuro prometido pelo aquecimento global. Noves fora fossilistas empedernidos e negacionistas, também não dá mais pra distinguir, à primeira vista, apocalípticos e integrados. Mais ou menos radical, toda campanha a respeito no fundo sempre imagina a geração presente sendo inapelavelmente julgada e condenada pelas suas vítimas do próximo fim de século, que por apenas quatro graus centígrados a mais poderá ser o fim de tudo, ou quase tudo. É preciso muita miopia passadista para não tirar conclusões dessa simetria jurídica que comprime o presente num espaço de perene acerto de contas. Apanhada assim no contrapé, não surpreende que a esquerda hoje tenha se tornado cada vez mais legalista e punitiva.

Resumo todo esse rodeio, antes de passarmos para o capítulo do sonho, pois até aqui estávamos no da esperança. O longo século XIX (1789-1914) e o breve século XX (19141989) foram sobretudo dois Séculos de Espera, sentimento político do mundo coextensivo ao novo campo de forças e expectativas inaugurado pelo capitalismo. Primeiro a es- 
pera da Revolução, temida na mesma proporção de ansiedade pela Reação. Em agosto de 1914, a explosão paradoxal da guerra, saudada por aqueles que marchavam com entusiasmo para o massacre como se entrevissem a luz de uma libertação, acabou revelando que a guerra também entrara no rol das grandes esperas do século, desta vez curto até o extremo do cataclismo nuclear, outra maneira de assinalar a entrada em cena de uma terceira e última espera, nessa escala descendente, marcada em todos os casos (energia nuclear incluída) pela reversão de um horizonte de expectativa no seu contrário, deixando atrás de si como experiência atrofiada apenas a memória dos soterrados de sempre nesse campo de ruínas acumuladas pela marcha conjunta do capitalismo e seu par antagônico, o socialismo real. Como o Exército Vermelho derrotara o nazismo na Europa, havia sim o que comemorar em maio de 1945. Logo os administradores da Bomba e dos Campos se encarregaram da demonstração inversa, inaugurando a última espera mencionada, a do Acidente Absoluto. Parece uma narrativa mitológica, mas é assim mesmo o progresso do esclarecimento humano como libertação pela dominação, como se mostrou num livrinho herético e desconjuntado publicado naqueles anos das grandes esperanças do imediato pós-guerra, e para o qual obviamente ninguém deu a mínima. Imaginem só, sugerir que a coalizão vencedora da guerra contra o mal absoluto, comunistas e liberais, partilhavam com seu inimigo das trevas o mesmo sistema de coordenadas de interpretação e transformação do mundo. É mais do que hora de voltar a pensar. Retornando, por exemplo, ao ponto da pergunta anterior, crença ou descrença na relevância da política tal como a conhecemos, tanto faz se institucional ou extraparlamentar. Pois foi na reconstrução europeia do pós-guerra que se conso- lidou a fé secular de todos os envolvidos pelo consenso keynesiano na capacidade política do Estado, devidamente calibrado em seu poder regulador pelo conflito social às claras e de papel passado, em contornar de vez as crises estruturais do capitalismo. Enquanto durou o arranjo, foi o paraíso da política de classes. Mas o que podia tal política? Se comparada com as primeiras três décadas do século passado, quando vanguardas sociais, artísticas e técnicas pareciam convergir para uma tempestade perfeita de expectativas nunca antes pressentidas, a rigor nada. $\mathrm{Ou}$ melhor, a afluência sob um guarda-chuva nuclear. Pensando bem, foi uma política de baixa intensidade, como as dezenas de conflitos armados que fizeram da Guerra Fria uma guerra fria só no nome, na verdade foi quentíssima, o mundo volta e meia escapando por um triz. Rupturas radicais tinham um teto, em geral na forma de um cogumelo termonuclear. Como demonstrado pela crise cubana dos mísseis, em outubro de 1962. Eu tinha vinte anos na época e, como todo movimento estudantil, para não falar no sindical, acreditava que a Revolução Brasileira estava a caminho, não seja por isso. Durante os treze dias em que o mundo ficou suspenso à beira do abismo, nossa única atitude política era ler os jornais e simplesmente "esperar" que se cumprisse a perspectiva absoluta do nosso tempo. Não tínhamos a noção, mas a sensação era essa. A noção viria muito depois, me deparando com uma observação de dois teóricos alemães sobre os quais pairava a nuvem radioativa produzida pela explosão de Chernobyl: diante de um horizonte de espera assim, que não cria nem desperta nada, regredimos à nossa condição intrinsecamente apolítica, a de pessoas sem resposta. Esta condição está se reapresentando hoje, supondo que alguma vez ela nos deixou de acompanhar, desde que a extinção da humani- 
dade tornou-se um fato tecnológico ao alcance da mão. Não mais diante da Guerra, mas diante de uma emergência planetária como a mudança climática, a racionalidade intrinsecamente apolítica da destruição mútua assegurada está de volta. Em primeiro lugar, como fatalidade. Nada que se possa fazer a respeito. Salvo mitigações tópicas e esperar, mais uma vez, torcendo para que o pior não aconteça. Ou então tomar a emergência ao pé da letra. Não mais tarde do que 1948, o constitucionalista norte-americano Clinton Rossiter propôs nada mais nada menos do que uma Ditadura Constitucional, depois de chegar à conclusão de que democracia e poder nuclear eram incompatíveis. A seu modo, era uma primeira adaptação, supondo que o Antropoceno tenha se iniciado com as primeiras explosões atômicas. Assim sendo, não surpreende que vez por outra volte à mesa a ideia de que a recorrência das emissões contemporâneas só poderia ser derrubada por um governo mundial de exceção permanente. E por aí vamos, como num filme de Stanley Kubrick. À medida que as cúpulas de coisa nenhuma sob pretexto de medidas a respeito da mudança climática se sucedem no vazio dos protocolos, e se aprofunda o fosso entre a gesticulação dos tais líderes mundiais e a marcha da apuração científica do estrago planetário, a catatonia política generalizada tornou-se uma evidência, contra a qual os lugares comuns da esquerda digamos clássica sequer identificam o alvo, um tempo medido por um outro relógio, o geológico, diante do qual novamente não há respostas humanas, salvo os costumeiros cálculos geopolíticos autodestrutivos que a esta altura todos os atores relevantes já fizeram, desde que começaram a precificar o carbono para saber quem chegará vivo ao próximo fim de século. Como no futebol, sei que o jogo só termina quando acaba. Mas sei também por observação direta que a agitação frenética que se chama política hoje é um velho e ilustre nome para inação e paralisia. Embora o que não falte nesse teatro de sombra sejam ativistas, sobretudo porque mudança climática tornou-se meio de vida para uma legião deles.

Passemos à outra palavra-armadilha da pergunta, se o sonho acabou ou não. Aqui também temos novidades. Numa era de expectativas rebaixadas e inteiramente rebatidas sobre o presente, podemos presumir que o regime político do sonho não é mais o mesmo, como nos tempos de um Ernst Bloch novamente, para quem o sonho diurno tinha uma função utópica, como na mesma época o sonho noturno para os surrealistas franceses interessados em ganhar para a Revolução as forças do êxtase. Já o sonho de John Lennon que acabou, era o da contracultura, do qual se despertou para o pesadelo da contrarrevolução careta surfando na onda destrutiva da restauração capitalista dos anos oitenta. As raízes da ultradireita renascida no Brasil de agora podem estar aí também. Mas voltemos à politização frouxa dos sonhos de agora, ao que parece acabando e recomeçando a todo momento, como uma espécie de barômetro da conjuntura mental. Todavia, a pergunta sobre o fim do sonho ainda exprime uma inquietação clássica, é a todo um sonho de época que ela se refere. Pois bem. No Brasil contemporâneo que está nos interessando, o Brasil popular que começou a entrar em cena quando a Ditadura virava Transição e a esquerda foi enfim legalizada, um sonho de fato acabou. Sem alarde. Não foi um despertar traumático no meio da noite, mas uma morte por inanição, o sonho acabou porque as pessoas simplesmente cansaram. As famigeradas energias utópicas sobre as quais tanto se discutiu para saber se estavam esgotadas ou não, a depender do paradigma adotado, se do trabalho ou 
do reconhecimento, provaram afinal que estavam mesmo exauridas não por equívoco categorial mas por motivo de canseira total, física e mental. Cansadas de gestão. Esse processo de exaustão física e política encontra-se exemplarmente documentado no filme de Henri Gervaiseau, Entretempos (2012), resultado de três anos de filmagens no canteiro do Mutirão Paulo Freire, na zona leste de São Paulo. Também remeto ao comentário do coordenador da assessoria técnica responsável pela execução do projeto, "Entretempos da luta popular". Quase dez anos depois de um dispêndio descomunal de energia, uma centena de habitações foram de fato construídas, e muito bem, porém aquela experiência de ação direta havia se tornado um fardo para todos, ao fim e ao cabo, o trabalho livre num canteiro autogerido parecia mais agravar o peso da alienação do que emancipar. Sonho da casa própria realizado por um coletivo de livre-produtores no qual a maioria não se reconhecia mais, e não eram poucos os que pensavam em ir embora. É que os mutirantes neste meio tempo mais pareciam uma tribo desgarrada de batalhadores exaustos num deserto urbano de conjuntos habitacionais medonhos, condomínios fechados de segunda, que o capitalismo popular, o mercado para todos, estava produzindo. Com o teto político rebaixado, todo um sonho de época se acabou, no caso, o sonho do controle popular das políticas públicas, para falar na língua dos movimentos. Sonho desfeito, sonho restaurado, para variar na escala descendente com a qual estamos nos defrontando. Pois foi um sonho restaurado pelo mercado que o sociólogo Adalberto Cardoso reconheceu nas ruas de Junho. O padrão FIFA exigido pelos manifestantes era uma aspiração racional. Num ambiente em que qualidade se tornou sinônimo de mercado, era natural que a aspiração da maioria por me- lhores serviços públicos, vividos nos circuitos da pobreza como sofrimento, penúria e humilhação, e além do mais suportados na consciência plena de que hospitais, escolas, não se fazem da noite para o dia e que a longo prazo estaremos todos mortos, demandar saúde e instrução agora só pode ser sonhar, e apenas sonhar, já que somos cidadãos de segunda classe, com hospital e escola privados. A quem pode comprar, só as empresas vendem aqui e agora as mais diversas soluções para seus infortúnios, novamente um sonho, pois a solução de mercado exige sempre cada vez mais renda, o melhor serviço sempre estará adiante. Precisando desesperadamente deixar o reino da necessidade o mais rápido possível, os trabalhadores pobres acordaram do sonho da construção de uma sociedade do trabalho emancipado para viver o sonho da vida coletiva mercantilizada, conclui Adalberto Cardoso. Se o lulismo poderia ou não poupar os mais pobres de sonhar um sonho assim tão mesquinho, são outros quinhentos. Além do mais, quem somos nós para criticar o que quer que seja, cada um sabe onde o calo aperta.

Independente da Luciana ter perdido e ficado bem atrás, o PSOL saiu da campanha fortalecido junto à opinião do eleitorado, sobretudo os de esquerda ou centro-esquerda. O PSOL está se tornando para o eleitorado, grosso modo, o que o PT foi nos anos 80 e 90? (uma opção política, depositário da esperança de reformas reais etc.).

Fantasia. Além do mais anacrônica. O que o PT não fez em mais de trinta anos de hegemonia à esquerda, não seria um similar em ponto menor que chamaria para si a responsabilidade de tirar o atraso. O que significaria hoje 
apresentar-se como "depositário da esperança de reformas reais"? Francamente. O etc. que fecha a pergunta já diz tudo, abrevia a canseira retórica inútil de enumerar todos os pontos clássicos de uma plataforma vencida. Não foi por crueldade social que o lulismo enterrou a reforma agrária, ou realizou uma verdadeira antirreforma urbana, coroada pelo monstrengo do Minha Casa Minha Vida, que deixa no chinelo os BNHs militares. Foi o que acabamos de ver. Enquanto um sonho de época se desfazia, um outro decolava. E não por acaso ambos giravam em torno de um sonho encravado no imaginário possessivo capitalista, o da casa própria. Quando se diz que o Brasil mudou, é para valer, não se trata de maré conjuntural. A partir do momento em que despertamos do sonho de uma sociedade do trabalho em construção, deixamos de ser uma comunidade política de expectativas imaginadas e nos tornamos uma comunidade de escolhas de produtos políticos oferecidos pelos governantes de turno e comprados, ou rejeitados, caso não satisfaçam determinado "sonho", pelos agentes de um novo mercado, o da cidadania. Saibam ou não saibam disso, governantes e empreiteiras associados, o Minha Casa Minha Vida está na direção certa, por isso é irresistível, como demonstram os últimos movimentos sociais a ingressarem no programa pela porta dos fundos do cadastro reservado a entidades.

Como o senhor viu o apoio de parlamentares do PSOL à Dilma no segundo turno? Foi coerente?

Coerente sim. São membros da mesma família histórica perdida no tempo. Compartilham a mesma memória política, internacional inclusive. Por isso sempre pega a síndrome de Weimar ou da Guerra Civil Espanhola. Sem- pre haverá uma hora dramática, eleitoral para variar, de cerrar fileiras e levantar os punhos para esmagar o ovo da serpente. Depois a vida continua, piorada.

Já há quem defenda que Marcelo Freixo, muito bem votado na eleição no Rio, saia para prefeito. Como "vacinar" o PSOL para não chegar ao "círculo do poder" $e$ repetir as vicissitudes da "governabilidade"? Como o senhor vê uma possível chegada do PSOL ao Executivo?

Se meu título eleitoral fosse carioca, precisaria amarrar a mão para não votar no Marcelo Freixo. Não há "vacina” pois além do candidato ser ótimo, as chances são reais diante do avançado estado de gangrena política do Rio de Janeiro. Depois da festa, restará o acerto com os reais donos da cidade, pois se trata de um caso especial de governo direto de um território urbano pelas empresas. Mas pensando bem, não era esse o raciocínio que se fazia para assinalar o impensável de uma vitória lulista? E no entanto. Mesmo assim, a a nalogia não cabe mais no Brasil de agora. O PSOL também está mudando, é cada vez menos um partido socialista clássico confinado ao extremo do espectro, e cada vez mais também um partido de nicho, pelo menos foi essa a tendência que saiu fortalecida nas eleições. Como se diz no mundo em que os governantes governam, a agenda anda, e encontra-se no momento em seu quarto estágio. Depois de encerrar o capítulo ditadura por disfuncional, estabilizar a moeda inflacionada, reconstituir o mercado interno de consumo de massa, dito também de inclusão social, entramos, tardiamente para variar, na etapa da polarização por motivo de confrontos inegociáveis em torno de valores, fenômeno que nos Estados Unidos, onde parece que tudo começou no fim dos anos 80 , foi 
batizado de guerras culturais. Do ponto de vista das campanhas eleitorais, o corte é ideal, é a festa dos marqueteiros arrombando portas abertas a preço de ouro. Basta enumerar as trincheiras para saber quem é inimigo de quem: aborto; casamento para todos; maioridade penal; todos os abolicionismos, do penal ao das drogas; controle de armas e desmilitarização das polícias; e claro, o decálogo LGBT, para ficarmos nos mais votados. Sem ironia. O céu aqui é o limite. Na França da Lei do Véu, já andaram botando fogo em presépio porque a república é laica. Até o aquecimento global já entrou na dança, dependendo de qual lado do front você esteja, será rotulado de profeta da desgraça ou negacionista. Como o regime presentista sob o qual vivemos nos tornou jurídica e politicamente contemporâneos de tudo e todos, as guerras culturais alcançaram a Conquista, a Escravidão, a Colonização, a lista em princípio não teria mais fim. Diz-se que no recreio dos liceus franceses a moçada se atraca xingando uns aos outros de colaboracionistas de Vichy ou cúmplices dos processos de Moscou. Já dá para perceber que cavando mais fundo nas ditas guerras culturais esbarramos na mesma lógica do acerto de contas, que ninguém se mostra mais interessado em abrir qualquer porta, do passado ou do futuro, dar enfim uma chance para a história avançar, como se dizia. Aí tem coisa, mal descrita pela bipartição usual entre conservadores e progressistas. Dou mais um exemplo e volto ao nosso possível candidato no Rio. O grito de guerra coxinha "vai pra Cuba" é menos estapafúrdio do que parece. Sem dúvida é um grito da má consciência depois da baixaria corporativista com os médicos cubanos, somada ao complexo da merda de nossa saúde pública (a privada é quase a mesma merda, só que paga) e muitos sintomas mais, sabidos e não sabidos. Nesse grito extemporâneo que é de fato uma ameaça e não um folder turístico, tudo se passa como se a Revolução Cubana tivesse estourado na semana passada. Pois bem, o nosso possível candidato no Rio retira sua força por ser um resumo desse quarto estágio da agenda eleitoral, e não um resumo qualquer, mas o de um vencedor no combate às milícias, só para lembrar que a gestão direta da cidade pelas empresas conta com uma linha auxiliar armada. Terá portanto força para negociar. E se ganhar, pelo menos nos cem dias de trégua que a praxe talvez lhe conceda, terá quem sabe mostrado que é possível passar a limpo no velho repertório socialista a nova linha da quarta agenda: que os direitos humanos são de fato a última trincheira da luta de classes. Disso tudo reteria a menção à estação derradeira, à última utopia, a dos direitos humanos, na opinião de um estudioso americano, Samuel Moyn.

E o desempenho do PT, que por pouco não perdeu a eleição, como o senhor vê? Ficou espremido entre o avanço da direita e a decepção com o partido de parte do eleitorado à esquerda...

Quem sou eu para avaliar o desempenho eleitoral do PT? Que descanse em paz. Bom, se eu fosse militante teria feito o seguinte cálculo: teria sido preferível perder agora do que ganhar nas circunstâncias vexatórias que se viu, e deixar a bomba explodir em colo adversário. Não seria desonesto, se é fato que foi a tal direita que lhe fez a cama. Desconfio que não acreditam mais no próprio taco. Visivelmente temiam perder e não voltar mais. E partido de governo fora do governo por muito tempo definha e morre. A base não sabe mais o que é fazer trabalho de base, perderam até a noção, em contrapartida seus bons qua- 
dros gestores não teriam muita dificuldade para se empregar, mas seria o fim político para todos.

O senhor acha que o cenário que vimos na campanha, sobretudo o avanço da direita, tem relação com as Jornadas de Junho de 2013, como alguns setores mais à esquerda afirmam? Se sim, em que aspecto?

É claro que tem relação com as Jornadas de Junho. Rompeu-se um dique e houve uma inundação coxinha como nunca se vira. Toda essa água represada estava lá fazia tempo, ruminando em silêncio uma vingança qualquer, de repente o levante. Como o repertório governista é muito restrito e datado, concentraram-se nas duas teclas conhecidas, provocação esquerdista e conspiração midiática. Depois na campanha eleitoral foi o que se viu, havia uma raiva nova pairando no ar. A inédita vitória nas ruas de Junho dera à legião coxinha a confiança que faltava. Ganhar no braço, e em movimento, correr da rua todos os vermelhos, reais e imaginários. Era uma questão de lógica que se completasse o serviço na eleição, e quase conseguiram, redobrando a fúria pela decepção de última hora na apuração. Parece psicologia social de bolso, e talvez seja. Penso todavia que foi o desrecalque do grande medo de 2002, pelo qual nunca perdoaram seus responsáveis, no fundo inocentes, pois não pretendiam assustar ninguém. Até mandaram carta. Fico acanhado ao ter que lembrar que ódio de classe no Brasil não tem cura. Nossa sociologia crítica formou-se procurando esclarecer a natureza desse misto de ódio e pânico provocado por toda e qualquer iniciativa destinada a aliviar a carga de opressão secular que desde a origem sufoca aqueles que se encontram na base da pirâmide. Entre tantas outras razões, concluiu-se até que era tão fundo e ancestral esse pavor que o povo esbulhado chegou a vislumbrar na relação de assalariamento uma via de escape relativo através do acesso a alguns direitos contratuais, tal a brutalidade da luta de classes básica em nosso país, a dos proprietários contra os sem nada, por aqui mexeu na propriedade homem vira bicho. Esse o segredo da mágica varguista. Pois vinte anos de ditadura baseada na tortura como política de Estado vieram para dar um suplemento de cruzada anticomunista a essa perene dessolidarização social, que é onde permanecemos meio século depois do Golpe, longevidade que se explica também pelos novos medos inoculados desde então, não sendo o menor deles o temor reverencial pelos militares, como se pode ver agora no show de impotência da esforçada Comissão Nacional da Verdade. Dito isso, acontece que a gesticulação acintosa da direita que quase levou tudo na última temporada, as ruas de Junho, o Congresso, a Presidência por um fio, ofuscou um quadro muito mais complicado de divisão social que esse clássico campo contra campo. Não dá para continuar ignorando a expressiva votação da direita no campo popular. Quer dizer, aos poucos o pacto conservador que emoldurou o lulismo está reconduzindo o voto popular ao seu trilho histórico, desde a orfandade varguista. Um ano ou dois antes de Junho já não eram mais tão raros os coletivos militantes na periferia de São Paulo que ao relatarem sua condição de estafa e desespero, ressaltavam um quadro de fundo de preconceito, fobias políticas e vale-tudo de todos os gêneros. Portanto devagar com o andor quando uma direita popular se insurge contra os pretensos vermelhos governistas.

Surgiram das Jornadas dois novos perfis: uma esquerda jovem e desapegada de partidos, parte reunida em 
coletivos apenas, e uma direita "raivosa", que vai pra rua, que usa as técnicas de manifestações que eram próprias da esquerda etc. Já conseguimos digerir essas "novidades", entender esse fenômeno? Não creio que dizer apenas "crise de representatividade" explicaria...

Como acabamos de falar da direita, vamos às novidades da esquerda. Historicamente, a esquerda no Brasil, todas as nuances confundidas, sempre foi mais a favor do que contra. Até a história jogaria a favor de um país periférico, condenado a avançar queimando etapas, condenado ao moderno, como se dizia, e sendo o moderno capitalista por definição, contávamos com a mola propulsora da acumulação para efetuar nossa travessia da Colônia à Nação. Como até o assalariamento chegou a ser visto como uma alforria do jugo proprietário e a ordem social competitiva, um ideal superador do Antigo Regime, era natural que fossemos mais anti-imperialistas do que anticapitalistas, sendo esta última atitude, aliás rara, anátema e sinônima de regressão romântica, como era costume dizer. Mesmo o esforço superador da condição subdesenvolvida era menos revolucionário do que industrializante, e centrado no protagonismo estatal. Dessa narrativa mítica, porém com forte apoio na realidade, surgiu uma esquerda devota do desenvolvimento pleno das forças produtivas e, por assim dizer, empenhada em botar para trabalhar cada vez mais gente. Não diria que não deu outra porque deu uma coisa completamente inusitada. Corta para nosso momento BRIC. Deixamos o subdesenvolvimento por uma condição dita emergente que nos alinha com outras economias capitalistas de Estado disputando com os velhos detentores da riqueza oligárquica mundial todo tipo de recursos de poder. E quais os mais desenvoltos e fervorosos combatentes desse combate pela História? A nossa velha e boa esquerda incansável de guerra, metida inclusive, desde que se tornou a parte mais esclarecida do bloco dirigente, nessa outra insana batalha de convencimento de uma recalcitrante burguesia, rebatizada muito a propósito de interna e não mais nacional. Pois enquanto vigorou, o consenso lulista entre proprietários dos meios de produção e seus gestores "populares" produziu outro consenso não menos perverso acerca de quem é quem dentro e fora do pacto da prosperidade emergente, em suma, saber de quem podemos passar por cima, basta estar atravessado no caminho de uma nova fronteira de acumulação, no geral por apropriação direta e em escala mega, do imobiliário à mineração. Mas só começamos a perceber no que andava metida a esquerda de governo, menos pelas famigeradas parcerias de tudo com todos, quando se multiplicaram e intensificaram os despejos selvagens, as remoções forçadas, os desaparecimentos nas periferias. Pinheirinho foi tratorizado na indiferença geral das classes trabalhadoras ditas organizadas, uma ou outra nota de pêsames descarregando a conta nas costas largas do neoliberalismo. Jirau nem isso, pois estavam diretamente implicadas na "pacificação". Vou poupá-los dos mundos e fundos do sindicalismo financeirizado, da fratura do precariado, para não falar da "classe" alinhada com os megaprojetos ou com os empregos gerados por uma próspera indústria bélica, à qual vieram se juntar também as empreiteiras. Aí já era tarde, o capitalismo popular havia ampliado o campo da Lei e da Ordem, um mundo ameaçado por forças oponentes, sabotagens e agentes provocadores. Até que houve a explosão de Junho, e os agentes oficiais do capitalismo popular de uma potência emergente de renda média se defrontaram nas ruas com uma exó- 
tica e incompreensível esquerda, recém desembarcada de um planeta desconhecido chamado anticapitalismo. Mais desconcertante ainda, foram nocauteados por um enxame de pivetes. Só agora, atônitos, ao se sentirem prestes a serem defenestrados com a mudança de maré do mesmo rentismo no qual estavam enterrados até o pescoço, saíram a campo para cortejá-los e ampliar o cadastro dos movimentos. Como a mágica está chegando ao fim, parece que não vai dar certo. E no entanto, essa esquerda anticapitalista amplamente minoritária fazia pelo menos uma década que manifestava pela ação direta de rua uma nota dissonante que até então no máximo atrapalhava o trânsito. Até que esse atrapalho entornou na total contramão da política tal como a conhecemos, nem mediação, nem representação e todos os seus derivados e similares no repertório básico da esquerda histórica, que reagiu à altura de seus fantasmas. Sobrou para todo mundo: levante niilista, tumulto fascista, gangues mascaradas e coisas do gênero. Digerir a novidade? Nem pensar. Até hoje não engoliram o fato abominável de que talvez haja uma ideia nova no país contrariando um século de nacional-progressismo com todo seu cortejo de comandos e transmissão de palavras de ordem. Por exemplo. Estando agora pela enésima vez "o petróleo é nosso" na berlinda, ainda outro dia li coisa do tipo: a presença desestabilizadora da tática blackbloc e assemelhados nas ruas de Junho seria uma armação da CIA para intimidar a Presidente e levá-la a entregar o campo de Libra, tendo como pano de fundo a convicção renovada a cada geração de construtores da nação, com ou sem uniforme, de que sendo o Brasil o país mais rico e viável do planeta, é natural que seja objeto da cobiça internacional... Não é, mas parece, ou logo vai se tornar, discurso sobrevivencialista, que afinal é o alfa e o ômega de todo o raciocínio geopolítico minimamente coerente com a lógica da degradação entrópica que comanda o reino da necessidade. Para piorar a maldição que paira sobre a ideia impatriótica de arquivar o senso comum nacional-popular, é que tal ideia intragável deu o ar de sua graça num momento de disseminação máxima entre o comum dos mortais, obrigados por lei a votar e a legitimar governos inoperantes, do sentimento de que a política não faz diferença em suas vidas. Ou quando a diferença é real a ponto de reduzir o sofrimento da pobreza extrema, como nos programas de transferência monetária condicionada, ela não é conquista de uma luta coletiva, mas efeito de um híbrido que deixaria Weber falando sozinho, racionalidade administrativa e carisma. E ainda tal ideia antipolítica costuma andar em péssima companhia, para não dizer coisa pior, um certo ar de família com o lema No Future do Punk original, ou como diziam os estudantes amotinados de Atenas em dezembro de 2008, e de novo em 2014, mesmo mês e mesmo bairro (Enarcheia), não nos move nenhuma teleologia (sic), como nada acabou, tudo começa. Não é mesmo fácil digerir essa ideia ainda não inteiramente identificada, acho que a ideia da geração que vem. Pois esta geração terá sido educada pela experiência de um sistema que se decompõe sem a contribuição de qualquer inimigo estruturalmente designado para abatê-lo. É totalmente vã a procura do sujeito antagônico clássico, pois seu apodrecimento ocorre pela inexistência de qualquer molécula anticapitalista. A gangrena de um sistema que não cresce mais e só produz dívidas se alastra sendo todos a favor. Enquanto houver planeta para consumir, governos que cortam gastos e liquidam ativos públicos continuarão a ser reeleitos. E os governos autointitulados progressistas da América Latina estão entre os principais 
devoradores do planeta, sem falar que, como mostrou recentemente uma pesquisa de Lena Lavinas, para o Sul Global, o modelo de Transferências Monetárias Condicionadas (CCT, na sigla em inglês) revelou-se uma eficiente política de financeirização da pobreza. É isso aí. Como notou um insuspeito sociólogo alemão, ao desmantelar qualquer oposição, o capitalismo está morrendo de uma overdose de si mesmo. Creio que é isso mesmo que no fundo está dizendo Linda Tirado, num livro extraordinário sobre a vida dos trabalhadores pobres nos Estados Unidos hoje, ao responder ao preconceito mais difundido acerca dos pobres: por que vocês fazem coisas tão autodestrutivas? A propósito, por falar no esgotamento real das energias utópicas, recomendo as páginas de Linda sobre o cansaço, e como a raiva é abafada quando se está estupidamente cansado. Tanto quanto um sistema que passou a operar em conjunto no modo "fim de jogo": na base, tornou-se racional para os pobres passar a junkfood; no topo, é cada vez maior a tentação de "vender tudo, pegar o dinheiro, queimar as pontes e deixar para trás apenas terra arrasada" e mesmo as esquerdas outrora organizadas hoje se encontram tão incapacitadas pela própria anomia do sistema que não conseguem mais nem mesmo salvá-lo, como na última grande guerra, o que dirá então derrotá-lo, soterradas pelo peso dos desastres diários. Restam os motins obviamente autodestrutivos. Ninguém mais está disposto a esperar mais nada.

Esse-vamos chamar de - "desgaste" do PT, assim como os problemas na economia, são sintomas de que o partido cumpriu seu ciclo no governo com sua política de inclusão social (que teve bons reflexos na economia também)? Quer dizer, parte dos que estão decepcio- nados enxerga o PT hoje como um partido como outro qualquer. O senhor concorda?

Como de fato todo um ciclo chegou ao fim, os balanços mais isentos não deveriam tardar. Acontece que se está verificando o oposto no clima de fim de feira de agora, pois também aumentou a cegueira da esquerda a seu próprio respeito. Mesmo a política de frente única que está se anunciando é meramente defensiva, além de chegar muito tarde, de fato para o enterro dos ossos de um programa que nem chegou a entrar em campo quando ainda havia chances, bem lá atrás. Precisamos saber o que realmente se desgastou agora que o PT luta apenas para sobreviver. Entre tantas outras iniciativas memoráveis, vou me concentrar na mais notável, a meu ver. O PT simplesmente inventou o governo de esquerda no Brasil, algo sem paralelo em nossa memória política. E isso muito antes de alcançar o poder executivo federal. Não sabíamos o que era isso. Salvo por contraste, tampouco ajuda a comparação com a social democracia, para não falar no eurocomunismo. Volto a lembrar que o Estado Social europeu é fruto do pacto político do pós-guerra. Por mais que aquele arranjo tenha confirmado as funções de acumulação e legitimação cumpridas pelo Estado então reconstruído com a reorganização do capitalismo depois da Grande Depressão e da Guerra, e a consequente funcionalidade de todas as instituições do Welfare, é bom não perder de vista que a força social capaz de impor aquela virada distributiva teria faltado não fosse a clareza do recado enviado a uma burguesia no geral conivente com o fascismo derrotado na guerra: nem pensar em voltar ao estado de coisas anterior ao conflito de 1914-1945, a república será social ou a revolução voltará à ordem do dia como em novembro de 1918 na 
Alemanha. Que Welfare de verdade se poderia esperar de uma transição pactuada com uma ditadura que não foi sequer desarmada? E no entanto, encontrou-se um caminho do meio absolutamente inédito no Brasil, esse o meu ponto. A decapitação dos comunistas e de sua dissidência armada pelo Golpe de 64 levou junto sua estratégia de tomada do poder. Inútil especular sobre o que poderia ter sido caso sobrevivesse à catástrofe. Um prefeito comunista de São Paulo? Uma contradição em termos ou um decalque do PT, criador patenteado da fórmula. No caminho da inédita conversão da maioria social em maioria política, o confronto simultâneo com a ditadura e a combalida tradição vanguardista das organizações leninistas, o PT foi preparando o terreno para a recepção, digamos socialista para abreviar, de noções e entidades que também na Europa estavam estreando roupa nova, da redescoberta da democracia na esteira do repúdio ao mundo soviético em ruínas ao reconhecimento da centralidade dos direitos, passando pela reativação em nova chave da questão social. Graças à galáxia movimentista reanimada pelo PT nos anos 80, o país conheceu uma inédita reinvenção do "social". Aquele mesmo social que na Europa foi criado para apaziguar o povo inconformado e frustrado pelo casamento da república dos iguais com a economia de mercado, no Brasil da dívida social de nascença, a nova esquerda concebeu o trabalho social como um prolongamento, quando não a finalidade, do engajamento político. E com isso, entre outras coisas, refundou o serviço público que a Era Vargas encaminhara e a Ditadura abastardara. Abriu-se o campo para uma outra cultura de governo, antecipada e alimentada em seu marco zero pelas setoriais do partido, como os veteranos devem lembrar e lastimar a anemia. Que o governo do social reinventado tenha dado no seu contrário é outra história que temos que investigar a sangue frio. A meu ver, a virada decisiva que tornou possível pensar seriamente em governar, desviando-se da estratégia clássica dos dois passos seguida pela esquerda clássica (poder popular só depois da aniquilação do poder burguês), deveu-se à descoberta movimentista da centralidade da política enquanto ato fundador de uma esfera emancipada do mundo das necessidades. A Transição propriamente dita pode ser descrita como aquele tempo conjuntural específico em que o dogma materialista da política como luta e dominação foi abandonado e arquivado. Quem jamais sonharia com políticas públicas de esquerda arrancadas de um poder de Estado redescrito como uma agência fornecedora de bens públicos na terra do patrimonialismo selvagem? E mais, em gestão de esquerda de políticas públicas? Resumo de época: nos engajamos, e cada vez mais participativos, nunca nos governamos tanto. É preciso tirar o chapéu. Pela primeira vez governar, em sentido amplo, de um mutirão de periferia ao gabinete de um mandato, produzia conhecimento social inédito e seus agentes específicos, uma espécie nova de intelectual público, em cuja caixa de ferramentas se encontrava um sem número de novas habilidades, do militante-socorrista ao pesquisador em missão. Saúde pública e saneamento básico, para dar exemplos antípodas, podiam agora gerar saberes combativos e de fronteira. Ocorre que por essa vertente, a tradição militante de que falávamos, no momento mesmo em que rejeitava a redução da política seja à dominação dos homens ou à mera administração de coisas, reencontrava uma outra costela de Adão do governo do Brasil, a dos assim chamados homens públicos, tanto faz, ou muito pouco, se conservadores, liberais e finalmente desenvolvimentistas, que simples- 
mente, ao começar do nada, consolidaram o papel exclusivo do Estado no processo, violento ao seu modo, de desentranhar algo parecido com um país de uma colônia de exploração mercantil. Miragem ou não, o fato é que ergueram um Estado peculiar, sempre na iminência de ser devorado pela praga nacional do patrimonialismo, por sua vez, como lembrado lá atrás, senha para o toque de reunir de todas as vocações para a responsabilidade que animam a tradição crítica brasileira, cujo lugar geométrico, de um modo ou de outro, encontra-se nesse aparato governativo a ser reconstruído ao término de cada ciclo predatório. Ao também se tornar, ao seu modo próprio, governo, a tradição militante, transfigurada pelo petismo que encorpava, cruzou o caminho da outra, insuflando-lhe nova vida por assim dizer retrospectiva, reconhecendo-se sem dificuldade em figuras exemplares como Celso Furtado, Anísio Teixeira, Darcy Ribeiro etc. completando-se a conversão da classe trabalhadora organizada ao esforço nacional de desenvolvimento do poder do Estado. Tanto mais que este poder não definhou com as privatizações, pelo contrário, aumentou sua capacidade de estreitar os laços entre todos os agentes concernidos pela acumulação, nela incluída os fundos ligados ao sindicalismo financeiro. Falta mencionar, mas apenas mencionar, a terceira perna desse governo do Brasil que, em conjunto ou sucessivamente, tucanismo e lulismo consolidaram. A redescoberta da política, como se viu, deixando para trás como relíquia arcaica a política da luta de classes, em qualquer de suas duas versões antagônicas, liberal e socialista, recebeu sangue novo também da reviravolta gestionária do mundo corporativo, que por seu turno também reinventou o social, mais exatamente a responsabilidade social, e tudo o mais que daí se segue, anunciando que a política dos políticos era mesmo o que as pessoas pensavam, um lixo. E tudo com muita participação e sociedade civil ativa e propositiva. Perversa ou não, deu-se uma confluência inédita, com o aparato estatal e adjacências operando segundo a mesma lógica gerencial. Não é que a reinvenção petista da política tenha sido anulada ou sequestrada, simplesmente seus futuros parceiros se puseram em movimento ao também se darem conta que seu público alvo se movera. Juntando as três pernas dessa fórmula tripartite de governo do país, teremos enfim identificado, na sua real natureza de tecnologia social de poder, o famigerado dispositivo chamado Neoliberalismo. O PT foi um de seus inventores. Ao beijar a cruz estava mesmo contemplando sua própria imagem no espelho do capitalismo contemporâneo. Estava certo. Se então é para falar em "desgaste", ele se refere ao conjunto da obra em seus três atos e atores. Esse o alvo real das manifestações de Junho e de tudo o mais que veio depois. Os que imaginam surfar daqui pra frente no levante coxinha vão quebrar a cara se acharem mesmo que o petismo é o único alvo da raiva geral.

\section{A esquerda está fadada a fazer concessões?}

Como qualquer um que não seja psicopata. O problema é que em mais de uma ocasião, e não por acaso em alguns momentos decisivos, o PT exagerou na dosagem do princípio de realidade. Foi assim com a Carta aos Banqueiros em 2002. Mas agora, no momento em que lhes respondo, ao anunciar um Ministério que deixaria Collor enrubescido, poucas semanas depois de entregar a política econômica do novo mandato a um mero executivo da alta finança que acabara de derrotar nas urnas, embora os bancos lhe ti- 
vessem financiado a campanha tão generosamente quanto a do seu adversário, a Presidente Dilma deu um passo à frente em direção a um princípio novo, o da irrealidade. É forte a impressão de completa desarticulação, de catatonia profunda mesmo. Pulsão de morte? Ante tamanho destrambelho decididamente a própria palavra "concessão" já não faz mais o menor sentido, se é que ainda fazia em nosso novo tempo do mundo, pois sempre encerrou um fundo de fé progressista no progresso, no caso progresso do esclarecimento social, onde o recuo de agora é a garantia do avanço mais à frente, assim na política como na guerra. Não mais. Até parece de encomenda para confirmar o pesadelo descrito pelo sociólogo Wolfgang Streeck, o alemão de que há pouco falávamos. Tudo se passa como se o capitalismo desorganizado estivesse desorganizando também a sua própria oposição, sem receita, não digo nem para salvá-lo in extremis, como fez quando sua sobrevida esteve por um fio à beira do apocalipse nazi, mas para escapar ela mesma, esquerda histórica, ao abraço dos afogados. Pois é esta a ideia nova em torno da qual estamos girando: o falso triunfo do capitalismo na Guerra Fria finalmente está nos levando a conceber o fim do capitalismo não como um evento mas como um processo, o fim de um fenômeno histórico que assim como começou deve acabar, mas um fim cujo desenrolar não seguirá nenhum plano, nenhuma toupeira vai escavando túnel algum, não se trata de mais uma crise de longa duração abrindo janelas de oportunidades para movimentos reformistas ou revolucionários. Como no fundo ainda esperamos por eles, o máximo que conseguimos discernir em meio à neblina, e repudiar com desânimo redobrado, são rebeliões primitivas que reforçam ainda mais a desordem. Ainda não aprendemos a viver sem receita. Aliás, foi mais ou menos isso que anteviu outro sociólogo, Silvio Mieli, num breve comentário em torno de suas primeiras impressões das manifestações de Junho. A seu ver, a idade épica das guerras e revoluções emendando umas nas outras, como na profecia verdadeira de Lênin, ou de Nietzsche, para as almas mais sensíveis, ficara definitivamente para trás, dando lugar a sublevações em que o corpo social se insurgirá através de uma série de atos profanatórios. Tudo somado, fazer ou não fazer "concessões" significava justamente naquele antigo tempo do mundo atrasar ou adiantar o relógio da história em cujo quadrante soaria a hora final. Só contemporizava quem julgava controlar o tempo, caso contrário era submeter-se à tirania da pequena política. Nossa imaginação continua prisioneira da ideia de uma intervenção salvadora que estanque uma hemorragia fatal, cortando o mal pela raiz. Em 2008, o diagnóstico era de morte iminente do sistema por falência múltipla financeira. À beira do precipício, os poderes centrais competentes não pensaram duas vezes: decretaram o estado de emergência econômica e torraram trilhões na operação de resgate, mas ficou a impressão de que salvaram o mundo na hora $H$. Pergunta de veterano inconformado com a falta de ideias e iniciativa da esquerda mundial, salvo denunciar o esbulho ciclópico: por que diabos não nos antecipamos e puxamos nós o freio de emergência? Sair à rua em massa e indicar a porta de saída. Estávamos é claro certos, o leite derramado sobre o qual chorávamos logo se espalhou para a Europa e levou à bancarrota os governos europeus mais vulneráveis etc. Não é esse o ponto. Mas sim a lembrança que não se apaga, nem deve, de que após três anos de uma guerra do fim do mundo, à qual ninguém conseguia mais pôr um fim, os bolcheviques disseram: vamos acabar com a guerra, expropriar a terra e distribuí- 
-la aos camponeses. Fico um pouco encabulado tendo que lembrar essas coisas.

Que balanço, político e social, o senhor faz dos governos petistas, de Lula a Dilma? Em uma conversa que tivemos, o senhor cita um aspecto dos governos do PT que teriam retardado uma "desintegração social". Poderia explicar melhor esse papel e o que o senhor chama de "desintegração social"?

Se falei em "desintegração", só pode ter sido um lapso, memória involuntária de antigos temores, na verdade um grande medo imemorial. Me explico. A sinecura que hoje atende pelo nome de Ministério da Integração Nacional é a expressão residual e degradada de uma aspiração ancestral de todas as nossas capacidades e vocações para a responsabilidade, à esquerda e à direita, para empregar ainda essas duas muletas facilitadoras. Superar os impasses do inorgânico, na fórmula inaugural de Caio Prado Jr. (1942), tão bem lembrada por Maria Odila da Silva Dias, a desarticulação estrutural que remontava à oposição básica entre dois núcleos opostos herdados da condição colonial, o polo metropolitano dos negócios de ultramar e o periférico, o inorgânico propriamente dito, a imensa franja de desordem em que viviam os desclassificados sociais, desgarrados da produção comercial-escravista. Sobretudo a partir das rebeliões da Regência, está claro que o fantasma é um só, tanto na visão dos formadores do Estado, sejam eles conservadores ou liberais, quanto na dos progressistas do futuro, a ameaça representada pelas forças de desagregação que a autonomia política então recente exponenciara. Entre esses fatores de desagregação, não ameaçava menos a assim chamada anomia dos opri- midos e marginalizados. Sob as mais diversas roupagens, da pacificação sangrenta dos separatismos à repressão selvagem dos inconformismos sociais, tanto o Império quanto o Estado Novo e a Ditadura de 64, se defrontaram e combateram o mesmo espectro da desintegração do agregado território-população, alternando a violência extrema que se sabe com inovação institucional, sendo a maior delas, até então, a legalização varguista do mundo urbano do trabalho. O objetivo era um só, segurança. De preferência com “desenvolvimento”, é claro. Aliás um projeto estratégico originalmente militar, como uma vez por outra relembra o cientista político José Luiz Fiori. Tivesse ou não clareza a respeito, a esquerda incorporou esse pesadelo das elites dirigentes sobretudo depois que elas começaram a dar sinais de que estavam se livrando daquele velho complexo tutelar. Daí a paulatina reabilitação do varguismo e do populismo desestigmatizado, e mais recentemente, coroando a obra, tive notícia de que o próprio lulismo também se compreende como herdeiro legítimo da missão histórica de superação dos supracitados impasses do inorgânico. Não estou dizendo que não, pelo contrário, só que, invertendo o sinal, lembrando que, no caso presente, o do Brasil contemporâneo, que emergiu do colapso da modernização, que por sua vez se declarou na hora mesma em que a Ditadura passava o bastão, superar o inorgânico passou a significar antes de tudo retardar por um lapso temporal, que hora e meia parece se encerrar, a desintegração cuja ameaça paira sobre o país desde a anomalia de seu nascimento, ao entrar de marcha ré na era do capital. Pelo menos a ênfase contraintuitiva do meu juízo talvez se deixasse explicar melhor se pudesse retroceder até os anos 80 de descalabro inflacionário e sua carga de desmoralização social, o auge da crapuliza- 
ção Collor da mesma elite que vendera a alma durante a Ditadura. Mas foi sobretudo a percepção de que o cinismo dos dominantes contaminara a violência dos pobres urbanos, condenados a sobreviver na adversidade, o que mais contribui para que o sentimento do mundo à esquerda naquela quadra de agonia fosse o de uma desintegração prestes a se consumar. Até que o lulismo elaborou sua estratégia de contenção sobre a plataforma do capitalismo de compadres armado pelas privatizações tucanas. Elaborou socialmente, imaginando estar transferindo poder ao trabalho que a reestruturação produtiva justamente desorganizara. Poderia resumir da seguinte maneira: como a construção da sociedade brasileira do trabalho, que Getúlio Vargas empreendera na forma de uma "cidadania regulada", na frase famosa de Wanderley Guilherme, fora definitivamente arquivada, inclusive como sonho ou utopia, como vimos na análise de Adalberto Cardoso, pensando restaurá-la, o lulismo simplesmente forjou uma outra cidadania sucedânea, e não menos eficiente em suas funções estabilizadoras e de legitimação da desigualdade, que poderíamos chamar de cidadania cadastrada. E não me refiro apenas ao 87 milhões de brasileiros listados no sistema de cadastro único do Governo Federal, o principal muro de arrimo, cujo alicerce é um real desempenho de urgência moral e cuja oportunidade histórica a paranoia direitista de hoje está ajudando a enterrar sem medir as consequências, como é próprio da atual lógica autodestrutiva do sistema. No lugar do trabalhador, seu ofício e o correspondente benefício, o reconhecimento pela inclusão num cadastro, que não é arquivo morto, mas precisa ser movimentado sem parar. O cadastro, escancarado ou não, é o principal dispositivo de governo desde que o ca- pitalismo se tornou um sistema para poucos. Do correntista num banco de varejo, ao prestamista e seu carnê, passando pelo professor universitário e suas agências de fomento, até e principalmente os lutadores sociais se esgotando no esforço de ser apanhado na rede de algum cadastro, é muito raro encontrar algum infeliz que não esteja prestando contas a algum dispositivo do gênero. Todos dançando para não dançar, como se dizia a três por dois. Ocorre que essa dança é tudo menos colaborativa, ela tende a construir mercados concorrenciais entre os próprios cadastrados, alguém estará sempre furando a fila de alguém. Nestas condições, é muito compreensível que cedo ou tarde gratidão se transforme em ressentimento. E que a implosão em curso de todo o sistema da cidadania cadastrada se deva menos ou quase nada ao encolhimento conjuntural do cobertor do que ao custo moral, esse sim excessivo, de carregar tal fardo de responsabilizações e suas contrapartidas. Mais uma vez, Junho pode ter assinalado a entrada em cena de uma cidadania insurgente de novo tipo, para falar como James Holston.

O avanço da direita no Brasil, para o senhor, tem relação com essa "decepção" com o PT? Sem deixar de lembrar, claro, que a direita avança em muitos outros países, parece um "movimento" global.

A decepção com o PT é uma exclusividade da esquerda. Até a mágica lulista o povo sempre o viu com desconfiança e pragmaticamente votava na direita que por sua vez nunca deixou de desprezá-lo e agora odeia por julgá-lo irremovível. É claro que não contaram com a benção de uma máquina de escândalos. Mas não é menos revelador de todo o enrosco de autoengano em que nos mete- 
mos que só estamos notando agora que a direitização é uma realidade em movimento no mundo. Simplesmente fomos dopados pela trégua lulista. Um armistício conservador, e passamos a acreditar que a pacificação social continuava avançando juntamente com a quarta população carcerária do mundo. Com o fim do cessar-fogo, a guerra voltou e não dá mais para recuperar o tempo perdido com o adeus às armas. Nem seria esse o caso, nenhuma refundação resolveria nada, os termos da luta presentista são totalmente outros, mas não vou me repetir ainda mais.

O caso petista de concessões à direita e ao capital não é isolado. Temos o Evo na Bolívia, elogiado pelo FMI; o Hollande na França, que deu uma guinada à direita, enfim. Como o senhor vê esses governos "populares $e$ progressistas" terem que fazer alianças com setores de direita e com o capital? É possível reagir ou escapar a esse "cerco" (do poder econômico)?

Guinada à direita do Hollande é força de expressão. Um bom teste europeu será o Syriza, caso chegue lá. Mas seria o caso de chegar lá? Lá onde a Troika o aguarda para comê-lo cru? Seja como for, logo veremos. Passemos aos autodenominados governos de esquerda na América Latina. Espero ter deixado claro que considero a expressão governo de esquerda se não uma anacrônica contradição em termos, algo que não sabemos o que seja, salvo, bem entendido, a inovação petista que procurei identificar. Não condeno ou aprovo os governos Lula-Dilma por julgá-los mais ou menos de esquerda ou de direita, o que seria uma rematada tolice, como já devo ter dito. Não me parecem argumentos a favor ou contra constatar tais alianças ou concessões. Afinal o que se espera do neoextrativismo a essa altura da vida? Não vale a resposta automática: financiar a coesão social. Adiamos o desastre com uma mão, enquanto o aceleramos com a outra. Qual a mão direita, qual a esquerda? Seja como for, o fato verdadeiramente novo que estamos testemunhando nesses países híbridos é que a roupa nova do antigo senso comum nacional-popular latino-americano deriva da circunstância inédita de estar se reapresentando em um cenário totalmente inesperado, a resistência e mobilização dos povos originários, cujo renascimento se dá em plena derrocada de toda uma civilização, no caso a do capital, verde ou não. Se a crise é terminal, o Bem Viver (Sumak Kawsay) algo terá a dizer no capítulo dos fins do capitalismo. Se o caso é de mera sobrevida, o capitalismo de recursos naturais, pois é disto que se trata, certamente terá a última palavra, mas o empate será mesmo catastrófico.

O que o senhor espera do novo mandato de Dilma? Os acenos são mais concessões à direita... Há esperança para um governo mais à esquerda?

Depende do fuso histórico da pergunta. No antigo, não espero nada, ou melhor, nada de novo. Nem a reviravolta pós-eleitoral tem novidade. A Presidente reeleita fez o que até as pedras de Brasília sabiam que faria, menos o seu eleitorado, que mesmo assim não deixaria de votar, tal o ambiente de luta mortal entre torcidas do mesmo time. Até o jogo duplo ensaiado pelas esquerdas, reunidas em frente única sob pretexto de combater a avalanche coxinha, é requentado. O teatro de sempre, o establishment político de turno se divide em dois, uma metade vai para a rua e pressiona a outra metade palaciana a ceder 
alguns anéis, a qual reage na mesma moeda de troca, até que o equilíbrio se desfaça e o jogo recomece. Foi assim com Getúlio e seus dois partidos, o desfecho foi trágico, mas ganhou tempo para o mesmo jogo ainda ser jogado por Jango, com o desenlace que se sabe. Uma terceira encenação, se ocorrer, sairá de cartaz em plena temporada. Se lhe desse uma resposta no fuso de agora, começaria a me repetir lembrando que esta não é a boa expectativa, e me voltaria a repetir dizendo que, sendo o tempo político de horizonte zero, certamente haverá carta nova no baralho, mas o baralho será o mesmo, gerencial e penal, muita Lei e Ordem com n programas "criativos" disso e daquilo se multiplicando como fogo de artifício enquanto a única demanda a realmente ser atendida será a de mais polícia. E desta vez não será trivial, não se trata de mera demanda por mais segurança pública, como de hábito. Literalmente, o tempo é outro. Um exemplo. Dentro de dois meses é bem possível que seis milhões de paulistanos não tenham uma gota d'água na torneira. Deixo de lado a gestão criminosa dos recursos hídricos pelos governos de plantão, seria chover no molhado, com perdão do péssimo trocadilho. É que não adianta mais trocar de governo, tanto é que situação e oposição entraram calados e saíram mudos na campanha, mal se tocou no clima de juízo final que se aproxima. Logo faremos diretamente o experimento de nossa condição intrinsecamente apolítica nessas horas em que as respostas humanas parecem se eclipsar. O abismo entre o que se sabe e o que se faz a respeito do aquecimento global, volto a repetir, não é apenas governamental, pior até, ou principalmente, o negacionismo é popular, como se os circuitos cerebrais das pessoas estivessem enovelados para não processar nenhuma informação a respeito. Por mais que saibam, não acreditam nos profetas da des- graça, sobretudo quando anunciam um desastre que mal se distingue em sua consumação em câmera lenta da rotina diária de milhões de urbanoides. E o poder de polícia nisso tudo? Como certamente gabinetes de crise devem estar cozinhando os mais variados planos de contingência, logo veremos. Fala-se nos corredores até de evacuação em massa (?!). É nessas horas que o poder soberano de exceção reemerge em todo seu hipnótico esplendor. A reeleição consagradora de um dos agentes da desgraça como o governador de São Paulo é uma confissão de impotência, carta branca que no seu devido momento será sacada. Dizem os especialistas em eventos extremos que o estado de emergência que eles deflagram constituem crises sem inimigo, ao contrário das situações de guerra, no entanto, basta ouvir o que um Oscar Oliveira (liderança que se formou na revolta da água em Cochabamba) está dizendo, para saber que a guerra da água faz tempo se desenrola em nosso continente e que dessa vez não nos defrontaremos mais com os nosso contendores de sempre no processo de acumulação por despossessão, governos e corporações associados, os inimigos estarão por toda parte na briga de foice entre cidadãos e comunidades pelo destino da água. O que seria uma resposta ecossocialista, que não fosse mero saludo a la bandera? É bem possível que se inaugure um novo período de assassinatos políticos com amplo apoio popular. Há armamento novo na praça e muita vontade de testá-lo, ou pelo menos queimar o estoque antigo.

E da direita nesse novo mandato? Os recados até agora indicam que será uma briga enorme, um desassossego, uma grande pressão. 
Por agora está sossegada, afinal ganhou. O recado é esse mesmo, e bem entendido dará para esperar 2018 numa boa. É até bom que as esquerdas convoquem jornadas nacionais de luta como a de 11 de julho de 2013, o fiasco previsível até contribuirá para o desfecho que todos esperam, novamente numa boa. Agora, se vocês estão falando da luta real, não tenho como saber, nem ninguém. Acontece que a esquerda produtivista além de derrotada demonizou o pessoal que sabe brigar. Com que roupa virão desafiar o que quer que seja?

Falamos hoje em "antipetismo", um esforço pela desconstrução do partido que traz aspectos preocupantes, de intolerância - houve ataques físicos a militantes petistas ou mesmo apoiadores. Como o senhor vê essas manifestações intolerantes e que lição tirar?

O antipetismo nasceu com o PT e só arrefeceu sob a anestesia da trégua social atribuída ao carisma pop (Tales Ab' Saber) do seu líder. O preconceito é de nascença, e embora seja obviamente de classe, nele estão unidos o assim chamado povão e a classe média, já os endinheirados são pragmáticos e não ligam para ideologia, desde que o governo saia barato, como foi o caso até agora. Quanto aos aspectos preocupantes da desconstrução do PT, o mais saliente deles é que a tal desconstrução é principalmente obra dele mesmo, algo inédito na folha corrida filosófica dessa noção abstrusa, que até hoje não sei como foi parar no jargão marqueteiro. Dito isso, que o antipetismo não é coisa nova, passemos ao capítulo aparentemente novo, a marcha triunfal da intolerância, que aliás não é uma exclusividade nacional. Mas por que o espanto? É verdade que não estávamos mais acostumados a apanhar em ma- nifestações públicas. Na velha política brasileira, pelo contrário, a regra era comício com muita pancadaria e, não raro, tiro. Nossa Transição Pacificadora, além do mais, ao aprisionar a política na gaiola dourada do ordenamento jurídico levou o autoengano até o ponto de sugerir a miragem de que numa sociedade afinal pacificada até mesmo o antagonismo entre as classes expressaria o espírito mesmo das leis. E no entanto, não se multiplicaram por geração espontânea desde então os tais Núcleos de Estudos da Violência, convertendo pesquisadores de talento em zelosos operários da Lei e da Ordem. Portanto devagar com o andor da intolerância, há muita bala perdida no pedaço. Ela é um sintoma por assim dizer multilateral, não tem lado certo. Na República Velha, e nem tão velha assim, costumava-se dizer que governar é abrir estradas, e, desde o Estado Novo, mandar prender. A Ditadura fundiu estas duas artes de governar em escala industrial, juntou megaprojetos com suplício, morte e desaparecimento. Pariu uma sociedade punitiva que só por preguiça mental e política botamos na conta sem fundo da escravidão. A esquerda hoje, seja lá o que isso queira dizer, costuma se esquecer de que em sua longa marcha cívica iniciada no apagar das luzes da Ditadura, é verdade que sem se dar muita conta, principiou também a surfar na nova onda punitiva e disciplinadora da virada gerencial capitalista e que não se restringe apenas à dimensão penal, como no encarceramento em massa dos pobres e demais "desprivilegiados", estendendo-se até os confins das menores células de sofrimento do mundo do trabalho. Afinal a esquerda preparava-se para apresentar-se como alternativa de governo e portanto era conveniente deixar para trás seu passado abolicionista penal, entre outras tradições libertárias do socialismo obviamente antigo. O fato histórico 
inédito é que desde então consolidou-se entre nós uma esquerda punitiva, como Maria Lucia Karam batizou o monstrengo. É só rebaixar o horizonte, e olhe que estávamos deixando uma ditadura para trás, para que o demônio punitivista salte da garrafa, invadindo qualquer sorte de plataforma de luta ao exigir punição exemplar para toda sorte de violação, ou desvio, na visão de seus pares antagônicos da nova direita. Homofobia, racismo, sexismo? Obviamente na forma da lei, mas punição sem choro nem vela, quem discordaria? Num ambiente de consenso em torno dos direitos humanos, ninguém. Antes de procurar saber se este consenso estaria se desmanchando por conta exclusiva da intolerância de ultradireita e se estaríamos de volta aos tempos dos "direitos humanos só para humanos direitos", dos inconformados com a extensão da alforria branca dos presos políticos ao povo barbarizado das prisões, seria muito útil voltar a lembrar que a propagação do discurso dos direitos humanos, tanto nos círculos bem pensantes dos outrora formadores de opinião, como nos círculos responsáveis pela conformação da nova razão governamental em vigor no Brasil pós-ditadura, se deu por um claro viés punitivista. Penso num estudo pioneiro de Helena Singer, complementar à identificação da esquerda punitiva por Maria Lucia Karam. Legislar e governar segundo o consenso dos direitos humanos também é mandar prender. "O senhor deveria sair algemado deste debate!" Não há quem discorde. O que se pede para sexistas, torturadores, corruptos, poluidores, motoristas negligentes? Cadeia, a mesma que a Constituição Cidadã reservou para os racistas. Assim como a alternativa à tirania do tráfico nas comunidades só pode ser outra coerção, a das UPPs, nossos ativistas espontaneamente traduziam a linguagem dos direitos gravemente violados em culpa- bilização, penalização e punição. Se confio na disciplina do castigo e na eficiência penal do poder punitivo, por que não confiariam no poder de transformação social da polícia, um trabalho social como outro qualquer? O renascimento cívico da esquerda culminou num consenso legalista em torno da política como moral e direito aplicados. Com que roupa se opor à fúria moralista da nova direita? Tudo se passa como se lamentassem o consenso perdido, justamente em torno do recurso à virtude curativa do castigo. Sendo esse o quadro histórico de fundo, o que significa, por exemplo, ser implacável na luta contra a homofobia? Poderia substituir o implacável por outro termo mais ameno, mas o espírito seria o mesmo. A saber, que a proteção de minorias estigmatizadas só estaria plenamente assegurada, para além dos discursos edificantes de tolerância e esclarecimento das trevas do preconceito, através de intervenções do sistema penal, que só poderá ser acionado obviamente mediante a criminalização das práticas e condutas odiosas. O punitivismo não é só apanágio da ultradireita, como pode ser encontrado até nas melhores intenções restaurativas, para dar um exemplo extremo, do roteiro básico da assim chamada Justiça de Transição. O que deveria haver de mais exemplar do que a punição de crimes contra a humanidade? Voltamos assim à forma tribunal de que falávamos lá atrás a propósito da destemporalização jurídica do passado e do futuro, este último na forma de uma representação da mudança climática como um grande júri moral condenando os perpetradores de hoje. Forma tribunal que voltamos a encontrar toda vez que os movimentos populares procuram simbolicamente levar os agentes da violência estatal ao banco dos réus. Sei que o terreno é minado e tenho, imagino pelo menos, perfeita consciência de poder estar resvalando no 
mais execrável dos amálgamas. Entretanto, o poder punitivo é o que é, uma tremenda máquina de confiscar conflitos e fabricar inimigos. A dissonância cognitiva não poderia ser maior. A palavra de ordem do capitalismo hoje é punir os pobres, na expressão consagrada por Loïc Wacquant. Não só prender e arrebentar os desviantes de sempre, antigos e novos, mas na outra ponta, castigar com a austeridade fiscal, entre outras disciplinas, os endividados, os imprevidentes, os populistas etc. Enquanto isso, correndo dos novos comandos de caça aos comunistas batemos nas portas da Lei como uma vez o camponês que não sabia que era personagem de uma parábola de Kafka. Mal comparando: é o que dizem os ativistas sul-africanos a propósito da derrocada dos movimentos sociais no pós-apartheid. Trocamos a ação combativa direta na construção do poder popular, dizem eles, pela rotina da apelação aos tribunais às portas dos quais se apresentam indivíduos estropiados em seu sofrimento individualizado clamando pelos direitos prometidos pela constituição: invariavelmente perdem. Aqui também será preciso periodizar. Como lembrei, a democracia das vítimas e seus violadores, consensualmente organizada em torno dos direitos humanos, era uma visão específica de quadros virtualmente dirigentes, além do mais numa conjuntura em que a hegemonia intelectual e moral estava com a coalizão liberal-progressista que conduzira a Transição. Quando essa visão se estabilizou e rotinizou na forma de Secretarias de Estado e Convenções Internacionais, além do mais tutelada por operadores burocratizados do direito, sobretudo em sua variante penal, como acabamos de ver, uma atmosfera benigna de fim de linha pareceu impregnar todos os agentes concernidos, tanto faz se eleitoralmente à direita ou à esquerda. Contra o pano de fundo incontro- verso de que a racionalidade econômica capitalista vencera, destacava-se o Estado Democrático de Direito como horizonte insuperável de nosso tempo. Convergindo todos para o centro, para falar à moda antiga, os extremos estariam mortos e enterrados. Até que, para espanto geral, a ultradireita renasceu das cinzas, primeiro nos Estados Unidos, depois na Europa, com toda força, livre para odiar. Seu desembarque no Brasil, em princípio pacificado pelo pacto conservador lulista, foi ainda mais surpreendente. A guerra voltou, mas no consenso básico não se toca, e, como vimos, não é só econômico, todo mundo quer criminalizar todo mundo. Mas é lá embaixo, na casa de máquinas da nova produtividade capitalista que o motor da crueldade social continua a funcionar a todo vapor. Não é só visão moral do mundo, embora o mérito do grande despertar para a luta final inegavelmente caiba à ultradireita que a esta altura já está engolindo toda a galáxia bem-pensante, aliás nem um pouco contrafeita.

A direita é que está se tornando "protagonista" das ruas ou foi a esquerda que, de certo modo e com a cobertura do governo PT, se acomodou?

Estava demorando, mas pelo visto entramos finalmente no capítulo da polarização, se entendi bem o foco da pergunta no inusitado protagonismo da direita. Comecemos pela rua. De uns anos para cá, ela já não estava totalmente vazia, mas hoje quem recomeçou a ocupá-la obviamente não foi a esquerda. Pelas leis da física, não podem governar e estar na rua ao mesmo tempo. Ao que parece, depois da surpresa de Junho e do enorme susto eleitoral, vão começar agora a terceirizar a função manifestante-indignado-com-o-avanço-da-direita. Mas não irei por esse 
caminho, ao longo do qual se encontraram em Junho coxinhas de festa na rua e ativistas veteranos dos movimentos antiglobalização. O fato é que uma inédita frente única de bem pensantes e neocons, não posso dizer que expulsou da rua um petismo que nunca mais deu as caras por lá. Prefiro recomeçar do zero essa história mal contada de polarização, ou melhor, nova polarização. Comecemos pela parte de conversa fiada. Papo de marqueteiro das primeiras campanhas televisivas de meados dos anos 80 . Polariza com fulano, polariza com beltrano. Ainda outro dia um dirigente petista posto em brios pelo opinião generalizada de que só a direita está partindo para cima lembrou que a campanha malhara sim o candidato $X$, depois o candidato $Y$, a propósito de tal ou qual factoide programático. Nada vezes nada, embora cumpra o papel de tirar uma candidatura do caminho. Passemos ao segundo degrau da escalada imaginária, a polarização entre PT e PSDB, que encobre uma verdade histórica, o fato de que nasceram na mesma e tradicional família do progressismo brasileiro, tão próximos um do outro que precisam se matar como Esaú e Jacó a cada volta do realejo eleitoral. Não posso agora reconstituir o sistema de vasos comunicantes entre o ABC operário paulista e a teoria social uspiana, talvez a amostra mais eloquente da intersecção, pelo menos na origem, entre dois capítulos decisivos das duas tradições mencionadas mais atrás, a militante e a crítica, surpreendidas ambas num momento de exercício efetivo de sua destinação originária de governo, dimensão afirmativa que plenamente desenvolvida nessa hora de convergência produziu a sociedade sem oposição na qual vivemos há quase duas décadas. Basta um exemplo, neste capítulo de exercício bipartidário do poder, quando Lula e FHC se uniram para conquistar o apoio de Bush logo após a temi- da eleição do primeiro, episódio da Grande Política (sic) cuja anatomia devemos a um livro de Matias Spektor. Aquela demonstração de que o Brasil tornara-se enfim um país governável rendera-lhe inclusive, no processo, sua elevação à condição de "potência emergente", muito antes da onda BRIC. Estava descartada a hipótese venezuelana, a saber: nem golpe com o aval do poder tutelar de sempre, tampouco o fantasma de uma real e irredutível fratura social, tal o fosso cavado pela predação anterior à reviravolta chavista. Assim, em lugar da temida polarização, continuidade de fundo, que é a que importa. Portanto, moderação de todos os lados, sendo o mais surpreendente o lado Bush, àquela altura de armas engatilhadas para a invasão do Iraque. E não se tratava de moderação extorquida em cima da hora, fazia algum tempo que o PT vinha se desradicalizando, enquanto o Presidente em fim de mandato, muito antes de render-se sabiamente ao pacote de Washington, já havia demonstrado durante os trabalhos de parto da Transição que era um sociólogo uspiano plenamente confiável. Pois no Brasil não há hipótese de ingresso no círculo real do poder no país sem demonstrações reiteradas e inequívocas de convicções moderadas. Não por acaso coube a um estudioso da história dos militares no Brasil, Paulo Ribeiro da Cunha, lembrar que o outro polo da moderação exigida é justamente o aniquilamento, que o digam os recalcitrantes, de Canudos ao Araguaia. Assim, foi necessário que um lado renunciasse à subversão e outro à ditadura escancarada. É bom ter isso em mente, a saber, que o núcleo duro do poder proprietário exige que seus quadros políticos sejam moderados a ponto de dispensar qualquer convicção que seja, salvo mera ostentação em palanque, ao passarmos para o próximo capítulo da escalada, agora sim, cada vez menos fictícia, da 
polarização. É que o pacto parece estar se rompendo, e do lado que menos se esperava, do lado direito, a ponto de um ala do a princípio esclarecido e moderado PSDB declarar que as portas do partido estavam abertas para as pessoas que estavam manifestando com arma na cintura seu horror à cor vermelha. Como vinha de um lado só, e lembrada a equação histórica entre governo e autocontenção do poder punitivo, que é o que moderação quer dizer, lembrei em nossa conversa prévia a paralisia da política americana por motivo de polarização assimétrica na expressão de dois cientistas políticos locais (Hacker e Pierson), aos quais fui remetido por um parágrafo de Wolfgang Streeck. Em resumo bem resumido, é o seguinte. Qual é a imagem consolidada da política interna americana? A de um empate catastrófico graças a uma escalada sem precedentes na, até então, sempre administrável rivalidade histórica entre os dois principais partidos do sistema, volta e meia o Governo Federal obrigado a fechar as portas por intolerância recíproca entre os operadores das facções em conflito. Conversa. Mas conversa da direita republicana, pois os democratas continuam onde sempre estiveram, à cata frustrada do eleitor médio, apresentando-se como alternativa responsável, realisticamente conformada para o compromisso. Daí a retificação. Há sim polarização, mas ela é assimétrica. Não só ela começa pela direita a cada volta ascendente da espiral do inegociável, como é saudada como renascimento da pureza ideológica, diluída na sopa das usuais coalizões de governo. Resta saber como e por que um partido de poder chega a preferir o bloqueio ao governo, a rejeitar e desprezar a formação de uma maioria nacional em nome da representação direta de um núcleo duro e estreito de preconceitos idem no front das diversas guerras culturais em curso na cena americana. O segredo da eficiência operacional desse aparente suicídio político reside no financiamento a fundo perdido pelo capital corporativo, liberando essa direita barra pesada da dependência do voto do eleitor médio. O objetivo tático é melar o processo legislativo, deixando o Estado à deriva e simplesmente impedir que haja governo, ou melhor, manter o status quo mas de preferência piorado, uma vez que governar nessa modalidade clássica desde o pós-guerra nada mais era do que uma "atualização" permanente dos instrumentos de adequação das políticas públicas às mudanças sociais inerentes ao funcionamento da ordem capitalista. Aparentemente esta última tornou-se ingovernável ou o seu governo propriamente dito, desinteressante. Em termos, é claro, desde que entendamos um pouco melhor o que significa uma estratégia destinada a impedir que haja governo. Nesse sentido, uma outra observação do mesmo Wolfgang Streeck pode ajudar. A seu ver, nossos dois cientistas políticos (Hacker e Pierson) estão dizendo que o bloco formado pelo capital corporativo e a ultradireita, que seu apoio financeiro deixa de mãos livres, funciona em relação às iniciativas bloqueadas do governo federal americano mais ou menos como a Comissão Europeia em relação às velhas prerrogativas dos antigos Estados da União, efetivamente impedidos de governar, por exemplo, sob o atual regime de austeridade, que o digam Grécia, Espanha e Portugal, para citar os casos extremos de destruição social decorrente dessa neutralização. Tudo se passa como se a derradeira superpotência, e por isso mesmo emissora do dinheiro mundial, por certo devidamente lastreado no exclusivo de um poder militar-tecnológico incontrastável, padecesse algo equivalente às restrições que a "globalização", de resto por ela mesma armada e impulsionada (em caso de dúvidas consultar o 
livro de Leo Panitch sobre a construção americana do capitalismo global), impõe sem dó nem piedade às populações do mundo. Realmente um grande rodeio para punir mais e melhor os pobres, para variar aproveitadores, indolentes etc. Mas cujo comportamento defensivo torna-se tão autodestrutivo quanto o represamento de toda e qualquer mudança. O mais espantoso nessa grande manobra suicidária é que a extrema direita cresce exatamente nessa brecha, que não cessa de se alargar entre governo inoperante e casta política self-serving de um lado, e cidadãos igualmente comprimidos, do outro. Inoperante é maneira de dizer. De um jeito ou de outro, governa-se, só que dispensando mediações, pois a burguesia nunca foi muito chegada em instituições, como mostraram suas administrações coloniais. Repito, trata-se cada vez mais de governo direto das empresas. Demasia? Volto a remeter ao caso bem real do poder metropolitano no Rio de Janeiro dos megaprojetos e das milícias estudado por Carlos Vainer, entre outros, e que o nosso destemido Marcelo Freixo se propõe a enfrentar com o poder do voto. Podemos? Trocadilhos à parte, os idealizadores do novo partido espanhol saídos do movimento de 15 de maio (8\% dos votos nas últimas eleições europeias apenas 5 meses depois de criado) acham que é possível sim o milagre que seria ainda votar de maneira tradicional e desejar ser representado sem trair o espírito do movimento de maio. Como nosso repertório foi roído até o osso, não podemos mais nos dar ao luxo de antecipar qualquer desfecho. Seja como for, pelo simples fato de colocar-se à margem do sistema político-eleitoral, a nova direita acabou protagonizando uma onda de repolitização, nos seus próprios termos é claro, mas nem por isso menos real, ao reintroduzir o inimigo no jogo de compadres dos negócios políticos correntes.
Não surpreende então que a direita de roupa nova reapareça com força redobrada desempenhando um papel protagônico (desculpe) igualmente novo. Corta para o Brasil.

Mas no caminho de volta, uma breve passagem pela Europa. Numa matéria de capa de um ano atrás sobre os possíveis Tea Parties europeus, a Economist também partia da constatação de que a principal inovação da nova direita americana residia mesmo no gesto aparentemente principista e inócuo de colocar a pureza ideológica acima das ambições de governo, mas não só, ao contrário dos congêneres europeus, outsiders de nascença, essa tática era operada no interior, e não à margem, de um grande partido mainstream por excelência, outra novidade. Do mesmo modo, a segunda constatação que nos interessa, o similar europeu também não precisa da vitória eleitoral. Não só para barrar "reformas" mas sobretudo para redefinir a agenda da direita estabelecida. Entandamo-nos quanto a barrar reformas, e aqui nos deparamos novamente com a funcionalidade das guerras culturais. Pensemos na batalha francesa em torno do casamento para todos. Mesmo com a lei aprovada, a direita está dizendo que irá derrubá-la assim mesmo, e está dizendo nas ruas partindo para cima da polícia como qualquer esquerdista quebrador de vidraças. Na observação do sociólogo francês Éric Fassin, num ambiente consensual essa é a nossa única batalha. Como de Sarkozy a Hollande é uma continuidade só, a clivagem ideológica precisava fixar-se em algum ponto nessa linha, de sorte que a questão do casamento para todos chegou na hora certa. Sim, dirá a esquerda, porque é uma proposição igualitária, relançando a bola para o outro campo. Sem dúvida, desde que nos conformemos com as regras desse único jogo. Como diria o Marcelo Freixo, é o nosso último front. E acho que 
o Pablo Ortellado concordaria, se entendi bem seu artigo sobre as guerras culturais no Brasil, segundo ele decorrentes de uma mudança de natureza do discurso político, que estaria funcionando num terreno novo de disputa, disputa discursiva cuja gramática seria preponderantemente moral, duas visões morais do mundo em combate, de uma lado punição e disciplina, do outro, empatia e solidariedade. Não vou dizer que não, apenas voltaria a lembrar que a pulsão punitivista, vinda dos subterrâneos de um processo econômico-social de seleção/eliminação, não respeita fronteiras. Seja como for, o fato é que com esse ajuste também encontramos nosso ponto de clivagem entre conservadores e progressistas, para usar a terminologia antiga que Pablo talvez tenha adotado para se fazer entender, mas que de qualquer modo não se encaixa mais nos parâmetros sugeridos por uma outra observação sua da maior relevância, a saber, que essas duas visões morais do mundo seriam incomensuráveis, ao contrário da cultura comum, que numa outra era, só contrapunha porque antes aproximava liberais e socialistas. Não empreguei a palavra era à toa, com perdão da insistência, é porque se trata mesmo de duas eras distintas, e a de agora, agora que passamos a viver num único dia que nunca termina, como se exprimiu há pouco Leonardo Sakamoto, esfregando os olhos diante da recaída do Prefeito de São Paulo na armadilha da tarifa, seria então a de antagonismos sem mediação, como se falava no tempo em que Hegel reinventou a dialética. Uma outra observação antes de retomarmos a conversa sobre polarização assimétrica, provocada pelo protagonismo da direita, cuja novidade está nos nocauteando e arrancando lugares comuns edificantes sobre fascismos e cia. Talvez seja verdade, como sugere Pablo, que devemos reorientar a luta e expressar nossa agenda de justiça social num discurso moral, antagonicamente categorizado por empatia e solidariedade, mesmo assim não posso deixar de salientar a simetria na argumentação: assim como já reorientamos essa mesma agenda, antes voltada para uma superação por vir, para a reparação de um passado de violações, fechando o círculo do presentismo de que já falamos. Mais uma vez o ônus do ajuste é nosso, os neocons saíram na frente, como conclui Pablo. De qualquer modo, por um outro caminho, sem dúvida oposto, chegamos de novo ao topo, à quarta agenda do neoprogressismo, como se há de recordar: democracia; estabilidade monetária; inclusão social; políticas de reconhecimento. Em termos clássicos, Étienne Balibar, há uns bons anos atrás diria que nesta escala ascendente de pautas ditadas pela conjuntura se manifestariam exatamente as três dimensões que a seu ver constituiriam o nervo da ação política: emancipação, transformação social e civilidade pacificadora. Mas voltemos. Pois acrescento que no caso da repolitização da política nos termos que estamos vendo nos Estados Unidos e na Europa, a direita não só saiu na frente como se insurgiu na frente. É essa a palavra empregada pelo redator da Economist, e para evitar o amálgama é preciso esclarecer que seu uso é corrente na prosa política anglo-americana, jornalística ou acadêmica, para caracterizar tanto processos de esquerda quanto de direita, civilizatórios ou bárbaros, desde que irrompam na contramão e caracterizando uma contrapolítica, isto é, ainda na reconstituição de James Holston, que estou parafraseando, a insurgência, nesta acepção, não é uma irrupção de vanguarda, a irrupção de cima para baixo de um futuro já organizado, e nessa compreensão do fenômeno a insurgência pode descrever tanto a sedição nazi quanto o levante zapatista. Numa palavra, a direita nacionalista e 
populista europeia se reapresentou na forma de partidos "insurgentes" e em ascensão. Além do mais são eles que estão assustando o mainstream, e não seus homólogos (sic) à esquerda, não obstante as reais chances eleitorais de Syriza e Podemos este ano. Ocorre que essa insurgência de cabeça para baixo tem prazo de validade. À medida que seu sucesso eleitoral cresce, principia a natural procura de respeitabilidade da parte de agrupamentos recém-saídos da marginalidade. Conhecemos o filme, o da moderação, acrescida agora de uma necessária descontaminação, pois a folha corrida deles por vezes é tóxica, além de sinistra. No processo, como sabemos, a pauta insurgente terá se tornado oficial, como vem ocorrendo faz tempo. Fim dos temores, mas não os nossos. Oficial ou não, ressentimento e raiva redobrados continuarão firmes e fortes.

Pois foram estes afetos políticos, entre outros, que interromperam o sono consensual brasileiro. Em Junho testemunhamos o inaudito, uma real insurgência coxinha, aparentemente surgida do nada e sem o menor termo de comparação com as provincianas marchadeiras de 1964. O problema é que este levante simbólico surgiu na esteira da real estafa do regime de cidadania cadastrada. Daí o nó na nossa cabeça. Diante dessa avalanche, o estampido inicial da esquerda digamos autonomista, à falta de melhor designação, necessariamente se vê reduzida à sua real proporção minoritária, além do mais atualmente sob ataque policial, judiciário e oficialista. Polarização assimétrica, mas não nos termos americanos, obviamente, sem excluir a hipótese de que de uma hora para outra também dê as caras no Brasil uma direita suficientemente poderosa para mandar às favas qualquer ideia de governo e seu cortejo esperado de moderações, equilíbrio, bom senso e similares. Não sabemos lidar sequer com a possi- bilidade desse fenômeno, pois nunca houve um partido ou coisa que o valha verdadeiramente contrarrevolucionário no Brasil. Por favor, não confundir com truculência proprietária, boçalidade política, ordem unida e assemelhados. Não perdemos por esperar, caso a cidadania coxinha insurgente se reconheça na militarização em curso da vida social, não diria nem induzida pelos vários governos de turno que se limitam a acompanhar, a reboque do processo. Mas isso já é outra conversa. Então ficamos assim: se for para reconhecer polarização plena apenas como toque de reunir e medir forças, como se dizia antigamente, acho que $o$ assustador mesmo durante a campanha eleitoral talvez tenha sido perceber na gesticulação ameaçadora dos coxinhas rebelados o arremedo grotesco de nossa própria compreensão da personalidade autoritária, que sociologizamos, psicanalisamos e etnografamos, durante gerações. Um experimento simples: é verdade que havia muito cristão novo nas fileiras dilmistas, convertidos recentes à causa do povo, mesmo assim partiram para cima dos traidores que nem mesmo útil votariam, como outros tantos casos de desvio patológico de personalidade. Aí sim a polarização foi simétrica.

O senhor disse no começo que abandonou a política institucional. Na esquerda o que o senhor enxerga de novo? Conhece algum coletivo, essa "nova forma" de militância que, algumas vezes, passa ao largo dos partidos?

Abandonei sim, mas não se trata de religião. Na Grécia, volto a recordar, consigo imaginar muitos amotinados do distrito Exarcheia em Atenas votando no Syriza dia 25 de janeiro, ou no Podemos espanhol, no fim do ano, 
até mesmo os irredutíveis do 15M. Se o Podemos estiver apenas "institucionalizando" a energia social e o processo de experimentação das jornadas de maio de 2011, logo saberemos. É claro que um brasileiro extraviado na Puerta del Sol ficaria com a pulga atrás da orelha. Afinal estão ou não estão rompendo com o consenso que levou a transição da ditadura franquista até a derrocada do falso milagre espanhol? Como se exprimiu o jornalista francês Renaud Lambert, o Podemos é uma hipótese. O PT e toda sua nebulosa de movimentos já é memória histórica. Mas à medida em que se estilhaçava, ia deixando cacos pelo caminho, mas cacos que não querem mais se reagrupar, conservando-se em estado avulso de disponibilidade para o que der e vier. Nestas condições, que sentido dar ao imperativo "é preciso retomar o trabalho de base"? À procura de uma resposta, foram se formando assim inúmeros coletivos de veteranos. Que por sua vez descobriram no processo uma conversa nova com os remanescentes do movimento antiglobalização da primeira década do século. Na esteira dos quais, por outro lado, principiou uma nova floração da cultura política libertária. Depois veio Junho. Aí já não dá mais para contar e repertoriar o enxame de iniciativas antissistêmicas. Tudo isso que mal conhecemos, pois achávamos que não havia vida fora das malhas do nacional-progressismo, em todas suas três variantes, militante, governamental e acadêmica. Mas o novo, há um ano e meio atrás foi de fato o MPL. Foi, hoje já não sei mais, tal a velocidade em que as inovações táticas vão se tornando obsoletas, como tudo. Mas nem mesmo esse antigo novo foi sequer digerido muito menos aceito, além de vilipendiado pelos dois famigerados "projetos" em disputa. Encerro me detendo um pouco em dois aspectos dessa novidade que em junho próximo completa dois anos sem sequer imaginar como será o próximo capítulo da mobilidade urbana em São Paulo. O primeiro deles diz respeito ao ato blasfemo de quebrar o monopólio da casta que controla a prerrogativa da iniciativa política na vida pública, privilégio do Estado, instituições e demais autoridades, incluído nestas últimas o dogma devidamente profanado nas ruas de que o campo popular tem um e um só representante. Não foi uma quebra qualquer, mas a capitulação da maior concentração de poder econômico, midiático e político numa região metropolitana brasileira. Só que esta proeza não comporta reedição, sua lógica não é mais cumulativa e ascendente. Ninguém conhece a receita do segundo ato. Como se não bastasse, redobrando a heresia, aquelas ações diretas de novo tipo, inclusive por terem um alvo preciso, no caso engolir de volta os vinte centavos de aumento, eram movidas por uma ideia inaceitável, horrenda mesmo (esse o segundo aspecto), a ideia de um movimento orientado para perder o controle de sua própria direção! Três vezes horror!! Um veterano observador da esquerda mundial contemporânea, suficientemente escaldado para não vender mais esperança em lata, observou certa vez que as ideias contam sim, mas não ao modo como direita e esquerda imaginam, no geral são concepções totalmente contraintuitivas, chocantes, incompreensíveis, como, por exemplo, as ideias iluministas de igualdade e liberdade numa era de desigualdades abissais e hierarquias de direito divino, ideias saídas de onde menos se espera e que milagrosamente redesenham a paisagem no instante mesmo em que uma onda social está se quebrando e revirando o mundo pelo avesso, com a qual elas, tais ideias, por serem incongruentes de nascença nada tinham a ver. Devemos começar a colecioná-las. 


\section{Post-scriptum: 0 nome da crise*}

Uma coisa é fechar o diagnóstico de toda uma época, nas minhas contas, os vinte anos do reinado FHC/Lula. Por mais que travem uma luta de morte por uma rapadura cada vez mais ingovernável, formaram um só bloco cujas raízes entrelaçadas remontam ao processo de saída da Ditadura, que por sinal acabou se confundindo com a derrocada de nosso meio século de modernização desenvolvimentista. A desintegração que seguiu foi provisoriamente estancada, porém num patamar social ainda mais rebaixado, mas ainda assim governável in extremis. Esse dique começou a se romper em Junho. Outra coisa imaginar o drama conclusivo que está se desenrolando agora sob nossos olhos. Não dava mesmo sequer para fantasiar que mal iniciado o segundo mandato, o governo Dilma estaria no chão, aplastado. A tal ponto que até mesmo a hipótese de um impeachment se tornou uma turbulência que valeria mais a pena economizar, uma má ideia, na opinião da Economist de 28 de março, mas não a ponto de estancar a paranoia dos que temem que um ajuste em si mesmo insano, como provaram ser os regimes de austeridade impostos à periferia europeia, possa dar certo (sic) e se inicie uma recuperação sob medida para uma vitória eleitoral lá na frente. Daí a correria intempestiva, ora à

* Este texto foi escrito na primeira semana de abril de 2015 como post-scriptum à entrevista "Entre os destroços do presente", em que Paulo Arantes procurava fechar um diagnóstico das duas décadas de progressismo brasileiro a partir do clima de "polarização" que aparecia como saldo do processo eleitoral de 2014. Neste post-scriptum, atento aos sismógrafos da "tempestade perfeita" que veio à tona nos "idos de março" anunciando a implosão, a poucos meses da posse, do governo Dilma, Arantes procura pensar o que significa a esta altura falar em "crise". frente, ora atrás das ruas em movimento. Seja como for, tamanha queda, e assim precoce e vertiginosa, jamais se viu. Mas não farei o diário da queda, nem recapitularei a escalada da crise que a precipitou. Como a saturação com todo tipo de palpite e especulação é geral, não vou nem de longe enfiar minha colher de pau na cozinha da conjuntura. Aliás logo estarão se multiplicando as inevitáveis reportagens investigativas sobre as grandes manobras que culminarão num desfecho que ainda ignoramos, embora desconfiemos que de qualquer modo não será uma saída para nenhum dos lados envolvidos nessa queda de braço. E se a queda que se avizinha, ou já aconteceu faz algum tempo, não for uma crise como as outras?

Nunca se falou tanto em crise, há crise por todos os lados e para todos os gostos, geralmente no modelo esgotamento ou exaustão disso e daquilo, encavaladas e se reforçando mutuamente. Em todo caso, nessa avalanche de diagnósticos, possivelmente ofuscados ou manipulando as guerras culturais entre "petralhas" e "coxinhas", ninguém se lembrou de reparar na falta de um ingrediente indispensável em todas as crises históricas do país, a subversão. E por uma razão muito simples e tenebrosa: ela foi extirpada com sucesso em 1964. Era essa a ideia, e de acordo com ela encaminhou-se a posterior legalização da nova esquerda, sendo a campanha de criminalização de agora o preço cobrado por aquele indulto. A crescente, inclusive em letalidade, gestão armada da vida social hoje obedece a uma outra racionalidade política, muito diversa do dispositivo militar de outros tempos, que dorme sossegado nos quarteis o sono da garantia da lei e da ordem, nos termos de uma Constituição que normalizou a relíquia arcaica do Golpe. Sem subversivos a caçar, salvo o resíduo amotinado de Junho, devidamente cadastrado pelas derrogações 
previstas nas brechas da lei, a crise pode até resvalar na anomia, cujas condições, segundo alguns observadores, estão dadas, mas decididamente se trata de uma crise sem inimigo, por mais que vermelhos e azuis queiram passar ao ato e se estripar. Crise sem inimigo: foi assim que nos anos 1990 alguns teóricos começaram a se referir às catástrofes desencadeadas por eventos extremos, "naturais" ou provocados por tecnologias de alto risco, querendo dizer com isso que estavam abandonando o paradigma militar predominante até então, ainda centrado na ideia de ameaças vindas de fora e percebidas como uma agressão desencadeada por agentes destruidores, sendo a crise, naquele modelo concebido ainda sob o efeito dos desastres coletivos da grande guerra e a paranoia da hecatombe nuclear, encarada como uma provação, a hora da verdade na qual a realidade oculta de uma coletividade se revelaria. Estaríamos assim, nesta crise sem subversivos de agora, como que diante de um evento extremo, a terra começando a tremer sob os pés de uma sociedade no entanto inteiramente pacificada desde a nossa última catástrofe, num outro março há 51 anos atrás.

Disponho apenas de uma pista nesta primeira tentativa de identificação. Até onde sei, lá pelo fim do ano de 2013 o prognóstico de que uma tempestade perfeita estava a caminho conheceu uma discreta difusão. Não pesquisei muito, mas parece que por essa época o ex-ministro Delfim Neto já anunciava em suas colunas que uma tempestade perfeita (ainda com aspas) se avizinhava, podendo desabar no primeiro semestre do ano seguinte caso não déssemos a devida atenção às "ameaças" das agências de rating de rebaixar a nota de crédito do país, sem falar no início do fim dos estímulos monetários americanos: em algum momento a "emergência" gerada explodiria num desequilíbrio fis- cal, inflacionário e cambial que reduziria a pó a economia nacional. Essa “conspiração" obviamente objetiva de eventos simultâneos resultaria na tempestade perfeita que nos puniria sem dó nem piedade. Nesse meio tempo devo certamente ter deixado escapar outras menções do referido alto personagem a essa conjunção tempestuosa que continuaria a nos espreitar caso não nos "ajustássemos”. Uma ocorrência na primeira semana de março, ainda na condição de espada de Dâmocles, trazia por certo embutida a memória da débâcle política e moral em curso.

Para quem não se lembra, a frase tornou-se comum no inglês coloquial americano desde que um bestseller com esse título, depois transposto para o cinema, consagrou-a como sinônimo de evento desastroso produzido pela convergência excepcional de circunstâncias adversas, no caso gerador da metáfora, o naufrágio de um barco pesqueiro colhido em alto mar pela combinação catastrófica de três tempestades, nada mais nada menos. Um outro naufrágio, o do Lehman Brothers e sua constelação de megadesastres, generalizou de vez seu emprego na caracterização de uma crise aparentemente de novo tipo. Desde então assumiu também, segundo pude ler na Wikipédia, uma conotação hipotética do pior possível entre todos os cenários.

De volta ao Brasil em "queda livre", segundo matéria de capa da revista Exame. Lá pelo dia 20 de janeiro, um colunista de O Globo cravava: a "tempestade perfeita" que os mais agourentos previam já está soprando com força mal decorridas duas semanas do segundo mandato, como se poderia constatar apenas pela escalada negativa dos indicadores econômicos básicos: impostos, taxas, juros, tarifas e ameaça real de desemprego rondando. Uma semana depois era a vez do Estadão, mas agora adicionando novos 
ingredientes, pois a nuvem negra da tempestade perfeita no horizonte seria sobretudo social. Ou melhor, social $e$ climática. Estava demorando a cair a ficha pois segundo consta o emprego original da expressão remonta a uma previsão um pouco mais estilizada de algum serviço metereológico norte-americano, variando apenas a data e o serviço concernido, reservando-se desde então a evocação do termo sempre que ocorrer uma combinação obviamente tempestuosa de muitos fatores. Há registros posteriores também quanto ao teor digamos literário da frase, como uma tempestade perfeita de aplausos ou de simpatia. Mas voltemos ao Estadão, ao resumo inspirado do articulista (José Roberto de Toledo): “enchente com falta d'água, calor excessivo com falta de energia, recessão com inflação, crescimento do desemprego com diminuição de benefícios a desempregados - tudo ao mesmo tempo". Agora? Ou daqui a pouco, tanto faz, o que importa mesmo é que no mais tardar em 2016 essa combinação estará entrando em fase com uma outra tempestade perfeita, desta vez fabricada no copo d'água explosivo das guerras culturais travadas nas redes sociais durante o período de fúria eleitoral. O ponto cego dessa "tempestade social perfeita" encontra-se na dramática dissociação entre fenômenos climáticos cada vez mais intensos, num cenário de oscilações também cada vez mais frequentes entre extremos opostos, e a rotina de inoperância imediatista da casta governante. Devolvendo assim a metáfora à sua matriz, e deixando um pouco de lado o para-raios da crise em que o mandato recém inaugurado se convertera, a primeira nota inteligente encontrada na enxurrada de comentários dos jornalões e adjacências, repercutindo uma queda tão ansiada e cavada, identificava na imagem da crise como uma tempestade perfeita algo como uma mudança radical do "clima" da política - o "tempo" que politicamente está fazendo -, na medida em que, persistindo justamente essa dramática confluência de circunstancias, “o cenário político vai ser radicalmente mudado pelo cenário climático”, e quanto mais radical o novo "clima”, tanto mais irá perdendo valor tudo aquilo que for apenas médio, do estatístico ao político - conforme a conclusão daquela nota preciosa, sem dúvida temendo por sua vez algum surto berlusconiano nativo, nada improvável ante o cenário de anomia que se desenha. E como vimos ao longo da conversa anterior, num ambiente polarizado como o atual, mesmo assimetricamente, dado o eclipse total da esquerda, as situações intermédias tendem a sucumbir, sejam as indefectíveis obras de infraestrutura rotineiramente projetadas para mitigar efeitos no entanto extremos, seja analogamente ideias singelas de repactuações políticas, também receita nativa clássica.

Ainda nesta mesma linha de caracterização de uma tempestade perfeita se formando pela conjunção dos dois extremos, o da reversão brusca e drástica das expectativas políticas e os sinais enviados para quem sabe decifrá-los pelo novo regime termodinâmico do planeta, cuja decodificação hesitante vai no limite alimentando um indefinido porém intenso sentimento de impotência, na exata acepção em que o evocamos lá atrás, a certa altura da nossa "entrevista", a propósito da inibição de certas respostas humanas comensuráveis, no caso de uma chuva radioativa por exemplo, o sinal de alarme já soara para a jornalista Eliane Brum, descrevendo para o El País o desenrolar da campanha eleitoral em São Paulo e seu rol de dissociações cognitivas aberrantes, a principal delas a pulsão negacionista ante o colapso do abastecimento de água na região metropolitana, candidatos e gestores da desgraça dispu- 
tando no máximo a autoria do nó no rabo do gato. A reeleição avassaladora do negacionista mor, que atravessou o primeiro turno repetindo "não vai faltar água" quando a água já faltava, é o fruto envenenado daquela impotência diante de uma crise do quê ninguém sabe ao certo. Segundo Eliane, o referido personagem foi de fato consagrado pela mesma negação da realidade que o eleitor queria confirmar, de sorte que venceu não apesar da crise da água mas também por causa dela, todos embalados pela mesma ilusão do controle. Como se trata de uma crença desesperada num futuro cuja data todos fantasiam, caminhões pipa com escolta policial farão parte daquele cenário político radicalmente mudado pelo cenário climático mencionado há pouco. Noutras palavras, um poder soberano de polícia, enquanto paradigma de governo das crises, será objeto de uma verdadeira demanda popular. Como meses depois, a demanda por intervenção, qualquer intervenção, desde que alguma coisa seja feita. Se há algo que deveria de fato assustar na atual crise com inimigo difuso, é a antevisão igualmente embaçada de uma passagem ao ato de todo esse sentimento de impotência.

Mas adiantemos o relógio. As chuvas abundantes de fevereiro e março lavaram a alma inconstante de governantes e governados e fez sumir do radar da tempestade perfeita, enquanto metáfora maior da crise, a sinergia dos extremos climáticos e sociais, substituída por uma outra confluência de tempestades adversas comandadas pelo espetáculo jurídico, do qual até agora ainda mal se entreviu o prólogo policial. Quando o bordão voltou - na mesma semana em que o Brasil atolado foi capa da Economist, depois de enumerar as razões que poderiam levar o país ao precipício, o Time também concluía que o Brasil parecia viver uma tempestade perfeita... -, a chuva de escândalos estava de volta ao seu lugar cativo numa crise invariavelmente apresentada sempre como tridimensional. Como é descrita, por exemplo, numa entrevista do cientista político Marcus Melo. Novamente uma tempestade (desta vez política) perfeita em que convergem políticas de austeridade ceifando empregos, megaescândalos e gente na rua. Embora ainda não tenha recorrido à imagem da tempestade perfeita, um outro alto personagem, FHC, que não dá ponto sem nó tal como seu desafeto Delfim, vem multiplicando declarações e artigos semeados de recados do tipo "chegou a hora", por enquanto apenas de "interrogação", nos quais não faltam a indefectível enumeração dos três elementos em sinergia desastrosa: na última contagem, pela ordem, clamor da rua, avanço do processo judicial e mídia.

Quanto à esquerda desmastreada, sente a tempestade mas ainda não a tinha nomeado, tal a obsessão conspiratória, acrescida da mágoa com a ingratidão de um sistema que a está expulsando pela porta de serviço, até que um artigo no Brasil de Fato, não resistindo ao bordão, colocou tudo, menos o novo "clima” da política, no copo d’água da tempestade perfeita, dos suspeitos de sempre, mídia golpista em primeiro lugar, ao inesperado reconhecimento de que no assim chamado campo popular reinam dúvidas, confusão e conflitos - a matéria é anterior aos $60 \%$ de desaprovação entre a renda familiar mensal de até um salario mínimo. E só. Mas não é pouca coisa admitir que desta vez o realejo do governo eternamente em disputa parece desafinar, tampouco o mantra da conspiração sai ileso, pois afinal a sabotagem parece vir de dentro, os infiltrados não são penetras mas convidados de honra. Mais uma vez, esse o ponto cego de uma crise não por acaso encarada como uma tempestade perfeita, que aos poucos vai 
deixando de ser um lugar comum nascido do jargão metereológico, na mesma medida em que a crise que ela anuncia já não corresponde mais ao antigo conceito de crise.

Como se há de lembrar, um conceito dramático por excelência, cuja aclimatação como conceito de época foi reconstituída nos estudos clássicos de Koselleck. Para efeito de contraste, que não poderia ser maior, uma recapitulação sumária dessa translação cujo ponto de origem se encontra nalgum lugar de uma antiga superposição de significações provenientes de três esferas, jurídica, médica e teológica. Em qualquer uma delas, estão em jogo alternativas sem resto entre certo e errado, vida e morte, salvação e danação, exigindo escolhas decisivas. No roteiro que estamos considerando, durante um longo período a acepção médica prevaleceu sobre as demais, seu uso metafórico estendendo-se aos mais variados domínios desde o início dos tempos modernos, salvo o surpreendente retorno, embora secularizado, de sua acepção apocalíptica, para lidar com a novidade da Revolução Francesa enquanto revelação de um novo tempo, precisamente o de um mundo sacudido por crises que anunciam tanto um fim quanto uma passagem de época. Desde então, encarada como uma espécie de abertura teatral de todo um horizonte de expectativas, a ideia de crise passou a admitir diversas filtragens, ora como um encadeamento de eventos culminando num ponto decisivo a partir do qual é preciso agir, ora como um ponto único e final, a partir do qual o curso histórico do mundo não será mais o mesmo. Desde sempre nos reconhecemos neste quadro, ao qual Marx acrescentou (ou nele se inspirou) a ideia de que as crises são soluções violentas de contradições existentes: socialmente destrutivas mas mesmo assim "soluções", é verdade que muito peculiares, nas quais se restabelece momentaneamente o equilíbrio rompido até a próxima erupção. Elas seriam o "negativo do capital", na formulação bem conhecida de Jorge Grespan, e nesta condição, essencial na definição da temporalidade típica do regime social presidido pelo capital. Desde sempre quer dizer desde que este regime específico de historicidade (François Hartog etc.), se abriu a perdurou durante dois séculos de grandes esperas, ao longo das quais gerações antagonistas foram completando sua educação política pela espera ativa do ponto crítico de uma reviravolta.

E se a rotina dessas crises recorrentes não for mais recuperadora? E se o estado crítico no qual se encontra o capitalismo hoje não apontar para qualquer saída digamos reguladora, para dizer o mínimo, tanto à esquerda ou muito menos à direita? Numa palavra, e se a crise, que não é de agora, for de um tipo totalmente novo? Pelo menos vai nessa direção Wolfgang Streeck, o sociólogo alemão ao qual recorri em mais de uma ocasião ao longo da "entrevista" feita ainda no escuro do apagão político que viria pela frente. Como se há de recordar, é dele a ideia duplamente herética de que o capitalismo está agonizando, mas que o seu fim é um processo e não um acontecimento disruptivo, e um processo destrutivo por incapacidade de autocontenção, uma vez desmantelados os mecanismos que historicamente exerciam tal função, como as falsas mercadorias trabalho, natureza e dinheiro, na distinção clássica de Polanyi, e mais, seu fim está chegando sem que nenhuma sociedade melhor e mais avançada esteja à vista e devidamente impulsionada por um sujeito portador da tarefa histórica de abrir-lhe caminho, o que suporia um grau de controle político sob o nosso destino comum com o qual não sabemos mais sequer sonhar. Sei que é duro de engolir, mas chega a ser quase intuitiva, quando se olha à 
volta, essa imagem de um sistema social em desmantelo crônico por razões internas e independentemente de uma alternativa viável. Mais duro de engolir enfim a ideia de que pode estar acontecendo da humanidade não se defrontar mais só com os problemas que pode resolver. Em tempo, isto não é o fim do mundo. Apenas o fim de dois séculos de espera "progressista”, encerrado justamente por uma crise de um novo tempo, por assim dizer empurrada com a barriga, ritualmente adiada pela compra de tempo, pela renovação dos prazos para o desastre, que ficará para a próxima vez etc. E no entanto, nada mais familiar do que esse cenário de inação, mal camuflada pela frenética proliferação de correções provisórias para gerir a multiplicação das crises de todo tipo no curto prazo. Salvo para aprofundar o estrago, como na concepção do capitalismo de desastre segundo Naomi Klein. Pela primeira vez (e última, por definição) Crise não é mais sinônimo de abertura de oportunidades, para agentes reformistas ou revolucionários, nem mesmo ou melhor, sobretudo, o aquecimento global enquanto janela de oportunidades para relançar a acumulação, muito menos, como argumenta a mesma Naomi Klein em seu último livro, a brecha para a reviravolta anticapitalista sonhada pela última vez, pois se é verdade que a mudança climática muda tudo, ela mudou também a natureza da crise, pois nesse cenário específico é ainda mais flagrante, nunca será demais repisar, a inoperância autodestrutiva geral. Definitivamente, não haverá mais um novo Agosto de 1914.

Vamos encurtar, já que por esse atalho chegamos mais rapidamente ao meu ponto. Vejamos se não é o caso: ao enumerar e reunir numa confluência desastrosa as cinco doenças sistêmicas do capitalismo agonizante de hoje por motivo de enfraquecimento das restrições (tradicio- nais, institucionais e políticas) ao seu avanço desimpedido (estagnação, redistribuição oligárquica, pilhagem do setor público, corrupção endêmica e sistêmica, anarquia geopolítica global), penso que o nosso teórico (Wolfgang Streeck) está descrevendo o desenrolar concatenado de uma tempestade perfeita, cuja duração no entanto pode se estender por anos a fio até alcançar a marca fatal dos dois graus centígrados a mais que arrastaria consigo o que porventura sobrar até lá, por isso o sistema não pode parar de comprar tempo. Que é inteiramente outro, para início de conversa, sendo outro, como sugerido, literalmente, o "clima" da política, como mudou o da história, revista pelo prisma do tempo geológico do Antropoceno. Mas passemos. A outra metade do argumento viria da redescrição da mudança climática também como uma tempestade perfeita, cada vez menos metafórica, como na "tempestade para os meus netos", de James Hansen. Para uma demonstração de A a $\mathrm{Z}$, sobretudo no que concerne à inércia política, à dilatação indefinida dos prazos, Stephen Gardiner construiu um modelo de tempestades convergentes, alimentadas por uma tal assimetria de poder que torna os agentes relevantes cada vez mais vulneráveis a uma espécie nova daquela corrosão do caráter identificada por Richard Sennett no mundo do trabalho contaminado pelas estratégias perversas de investimento no capital humano. Tudo bem pensado, nos dois processos de agonia como tempestade perfeita, a do capitalismo e a mudança climática, dois metabolismos enfim reunidos num só bloco comido pela entropia, ainda falar em "crise" é apenas uma maneira de dizer para nos fazermos mal e mal entender, pois saiu de cena o personagem capaz de tomar decisões no ponto crítico máximo da crise, ou melhor, como a cena é de inoperância e muita gesticulação ao 
redor, este ponto de virada pode até dar o ar de sua graça porém inutilmente, tal a amplitude do "tétano do não-ir-adiante" que essa crise sem crises propagou. Feita a ressalva, podemos até compreender o vocabulário e a gramática da crise, mas o seu imaginário de fundo, histórico aliás, já não é mais o nosso. De um modo ou de outro, sabemos disso. Tanto que a imagem da tempestade perfeita se alastrou até a saturação, e como tal nos alcançou num momento em que logo faremos a experiência de que a hipótese de uma estagnação secular já é o "novo normal", nas palavras de um oráculo financeiro em Washington, e sumidades neokeynesianas dizendo amém.

Então é isso, a tempestade perfeita que está nos sacudindo é mais que uma simples metáfora para uma crise mais inusual do que as usuais, tanto é que compartilhada (argh!) por gregos e troianos, na verdade a sinalização em busca de um conceito comum. De sorte que a "seca" anunciada pelo regime de austeridade em que estamos entrando para valer, por exemplo, pode ser entendida igualmente como um evento tão extremo tal como a outra, a seca propriamente dita e que isto que pode parecer apenas um jogo de palavras, isto sim, "muda tudo", como no título do livro em que Naomi Klein narra a guerra do capitalismo contra o planeta. Extravagancia? Pode até ser, nunca se sabe. Todavia, não seria menor o disparate imaginar, ao contrário, que a hora é agora, que chegou enfim o momento de tirar da cartola da crise um coelho novo porém idêntico ao falecido quando jovem. Não será demais insistir mais uma vez, agora na intenção da geração antagonista que irá literalmente respirar os ares de um outro planeta, que o clima da história também mudou, por isso a crise não comporta mais um momento ótimo de resolução, pois é uma longa tempestade perfeita.

\section{SINAL DE MENOS*}

No seu livro O novo tempo do mundo, você nomeia as manifestações de junho de 2013 de "ruptura" e diz que "o país não voltará mais a ser o mesmo". A mudança parece que está na ordem do dia desde então e se tornou uma palavra-chave. Nas eleições, os candidatos de oposição diziam representar a "voz das ruas" e a presidenta reeleita se apresentava como a garantia de continuidade das mudanças. Mais de um ano depois, experimentamos alguma mudança?

Não sei se é mudança, mas de lá para cá, por onde tenho andado nestes últimos tempos, não se fala de outra coisa: a verdadeira "aparição", pois se trata mesmo de uma assombração, de uma nova direita, ou ressurreição repaginada da antiga. Seja como for, quem sabe uma paradoxal direitização da direita. Noves fora a polícia, apanhamos nas ruas de Junho como há nunca não se via e ainda não conseguimos identificar o agressor. Falar em fascismo pode até tranquilizar, na medida em que pensamos saber algo a respeito. Mas são tantas as ressalvas históricas que acabamos na mesma. Tampouco ajuda muito o aplicativo "neoconservador", salvo para efeito de comparação

* Perguntas formuladas em dezembro de 2014, por Marcos Barreira e Maurilio Botelho, respondidas em fevereiro de 2015, publicada em Sinal de Menos n.11, vol. 2, 2015. 
seguido de contraste com os neocons norte-americanos. Mas eles são mainstream, e estamos procurando equivalentes nativos do Tea Party e seus homólogos europeus. O fato é que fomos apanhados de surpresa. Doze anos entorpecidos pela presumida pacificação lulista embotou nossa percepção de qualquer nota dissonante, sem falar que a essa direitização da direita correspondeu, na direção contrária, porém há muito mais tempo, uma acentuada desradicalização da esquerda. É tão flagrante essa assimetria entre uma direita que hoje arreganha os dentes e uma esquerda legalista, que só mesmo o teatro de sombras de uma campanha eleitoral para sugerir a existência de uma polarização política de verdade. O lulismo é sabidamente fruto de um pacto conservador: resgatar em suaves prestações uma dívida social que sempre pesou na consciência das elites porém sem ônus para o capital. Com a agravante de que a famigerada inclusão pelo consumo, ao consagrar o ideal de uma relação estritamente aquisitiva com os bens e serviços públicos, tornou-se de fato o principal combustível de uma nova direita popular, dividida entre a demanda self defeating da Lei e Ordem, de preferência sob as asas de uma aliança entre o Espírito Santo e a Bancada da Bala, e o reconhecimento sincero, traduzido em votos, de que numa sociedade do desprezo finalmente alguém olhou por nós, e um dos nossos, além do mais, reavivando a memória, mas apenas a memória, da Era Vargas. Nestas condições, obviamente a despolitização sobe aos céus, emendando na massa amorfa dos coxinhas, pasto preferencial dos incitamentos de passagem ao ato que circulam pelas redes sociais. Pois dessa multiforme e policlassista continuidade conservadora de fundo brotou a ferocidade de agora, enfim livres para odiar e espancar. Se não há nem em sonho subversão à vista, por que tamanha onda reativa? Passamos a respirar uma atmosfera tóxica de Restauração sem que nenhuma Revolução tenha destruído o Antigo Regime.

Já que mencionamos, a título de miragem, a sequência histórica Antigo Regime, Revolução e Restauração, reconsideremos o termo de comparação francês. Há mais de trinta anos as periferias francesas se insurgem, e partem para cima de uma polícia cuja norma é o desrespeito e a humilhação como instituição, o "esculacho" em bom português. A resposta é o fogo, o quebra-quebra e o saque. Jamais lhe ocorreria o disparate político de uma tomada do poder, como se dizia no tempo em que o capitalismo era um regime de organização e exploração em massa da força de trabalho. Mesmo a extrema-esquerda radical fala cada vez menos em revolução e cada vez mais em uma insurreição a caminho. Na opinião desconsolada de um Pierre Rosanvallon, proliferam os movimentos negativos característicos de uma sociedade em estado de secessão, dos quebradores de vitrines aos agricultores que não querem pagar impostos, passando pelos inimigos do casamento para todos. O que se vê na França de Eu Sou Charlie é um país em ordem unida caçando jihadistas. Mas quando estufam o peito num mesmo grito, dá medo. Essas temporadas de caça mútua destinam-se menos a prevenir uma convulsão sediciosa imaginaria do que manter sob controle uma sociedade que arrisca implodir conforme se multiplicam toda sorte de separatismos sociais. A extrema direita limita-se a exprimi-los com a mesma violência que os produziu. Além do mais, desde que ultrapassou a barra dos $20 \%$, ela está mais interessada em ganhar respeitabilidade e entrar pelo voto nas coalizões do poder, que de resto faz tempo já governam camuflando o núcleo duro da sua pauta assimilada da ultradireita, que ao fim e ao cabo 
está marcando o compasso de toda esta contradança securitária. Como ficamos? Acho que na mesma. A menos que adotemos a visão nostálgica e edificante do mesmo Rosanvallon: com a contração do mundo do trabalho, os vínculos anteriores de solidariedade de classe se dissolveram, arrastando consigo o conjunto da sociedade que, pulverizada e pressionada pela nova desgraça econômica, passa a atirar para todos os lados. Numa palavra, a solidariedade social recua. Nada mais francês do que essa lembrança da invenção centenária do Social, mais exatamente a lenta montagem do Estado Social destinado a acomodar patrimônio e trabalho de modo a garantir proteção e direito para os destituídos de propriedade, lembrança da invenção sociológica concomitante da Solidariedade à maneira de Durkheim, mas sobretudo lembrança de que ao longo do século XIX o país esteve mais de uma vez à beira da guerra civil. Tornou-se assim lugar comum da sociologia francesa declarar que o refluxo dessa mítica solidariedade social provocou um deslocamento da dimensão material do conflito social, que deixou de ser meramente distributivo para se tornar "cultural", mas um cultural na base do choque e violência. Sobre o cenário de fundo consensual acerca da inexorável disciplina do mercado. Mas como penso não ser o caso de adotar esta narrativa, continuamos na mesma quanto ao fantasma da polarização brasileira por iniciativa de uma direita que inegavelmente saiu na frente. Mesmo assim temos novidades no capítulo. Penso na contribuição de Pablo Ortellado, para quem não conhece, autonomista de origem e muito ativo nas ruas de Junho, contribuição que já comentei numa entrevista à Caros Amigos.

Pois vamos lá. Voltemos ao original americano da conclusão francesa de há pouco. Agora o paradigma da luta é outro, ele é antes de tudo cultural: justamente as "guerras culturais" travadas nos Estados Unidos a partir dos anos 1980 e nas quais Pablo identifica uma possível chave de interpretação da atual onda de ultradireita no Brasil. A seu ver a nova polarização não deve ser posta sem mais na conta de Junho, ela vinha de antes, as ruas e as redes apenas escancararam e intensificaram o choque entre duas visões antagônicas que não se reduzem mais à velha oposição entre socialistas e liberais, entre justiça social e livre empresa, mas antes a subordinam a um novo discurso de cunho moral. Novamente, nessa mudança de paradigma na retórica do conflito social, a iniciativa coube à direita, cujo senso histórico da injustiça necessária foi aos poucos transformando-se numa visão moral do mundo punitiva, disciplinadora, excessiva, intrinsecamente desproporcional, na sua reação ao que considera erro ou desvio a ser sancionado sem dó nem piedade. Não direi que não, pelo contrário, o capitalismo hoje, como mostrou Wacquant, é uma onda punitiva só, começando pela intensificação do trabalho dessocializado até o encarceramento em massa das categorias sociais recalcitrantes. Em suma, uma dessolidarização social em regra. Na França, como vimos, uma reviravolta cuja onda de choque é mel na sopa do ressentimento social no qual a extrema-direita foi a primeira a investir. No Brasil também tem sido um choque, sobretudo nos meios progressistas cuja má-consciência também é de fundo moral, sempre em dívida com as vítimas dos estragos perpetrados por seus ancestrais. Não sei se acompanho Pablo em sua conclusão, que no entanto compreendo em sua procura de um contraveneno à altura do novo jogo retórico da ultradireita, um contradiscurso de ordem moral porém centrado nos valores opostos da empatia e da solidariedade (como era de se prever). A nos- 
sa moral e a deles de novo? Igualmente incomensuráveis como nos tempos de Trótski, só que agora a chave é outra, a dos direitos humanos. Uma exortação envenenada todavia, desde o berço aliás, como mostrou Helena Singer, lembrando que a juridificação da utopia iluminista dos direitos humanos deu-se sobretudo pelo código penal. Sei muito bem que Pablo, veterano dos movimentos antiglobalização, não tem parte com a esquerda punitiva e legalista, cuja espinha eleitoral nem por isso a direita de todos os tons está menos empenhada em quebrar, mas sei no entanto que é essa mesmo a única agenda que prospera, desde que as grandes expectativas do horizonte moderno saíram de cena, é o último front, presentista por excelência, fazer a disputa do sentido moral da vida política e social imaginando que a gramática da solidariedade, a rigor confinada à política da redução de danos, também inspire uma reorganização do campo econômico. Aliás, pensando bem, ênfase moral a menos, não foi muito diferente a redefinição do conflito social pela esquerda dos tempos da Transição, Constituinte e corpo a corpo com o demônio de direita da hora, o Neoliberalismo e seus derivados. Mesmo jogo retórico, disputa semântica, como se dizia nos anos 90, só que com os polos da iniciativa invertidos: a esquerda, que descobrira a Democracia Participativa e reinventara a Sociedade Civil, obviamente ativa e participativa, saíra na frente e precisou enfrentar no seu próprio campo a confluência perversa do ativismo empresarial que despertara de seu sono dogmático dos tempos da rigidez fordista e falava a mesma língua dos movimentos sociais atravessados no caminho do terceiro setor. Com o enrijecimento do discurso movimentista, a direita endureceu e retomou a iniciativa do jogo, deixando a esquerda correr atrás precisando também subordinar seu velho discurso a um novo, que agora sabemos só poder ser de ordem moral, sem o que a ultradireita passará por cima. Isso significa não ter mais a história a nosso favor. Esse o campo minado depois de Junho.

Uma das articulações que você faz no livro é entre um novo tempo de "expectativas decrescentes" e a ideia de uma "era de emergência". Por outro lado, nos discursos oficiais das organizações internacionais e da grande midia sobre as "economias emergentes" vemos um otimismo em torno da redução da pobreza, ampliação do consumo etc. Há uma contradição aí ou a expansão da periferia capitalista tem prazo limitado?

Sei que estou pagando um preço pelo duplo sentido da palavra "emergência". Tanto situação crítica requerendo resolução em regime de urgência, quanto uma segunda acepção positivadora, geralmente associada à ideia de ascensão social, quer em sua versão meritocrática ou, mais duvidosa, sugerindo algum tipo de arrivismo, que por sua vez pode ser enobrecido à maneira dos personagens napoleônicos de Balzac, ou escarnecido como simples novorriquismo. Foi este último perfil que colou no Brasil, difundido pela ostentação dos "emergentes" da Barra nos primeiros anos da Era FHC, depois estendido, com segundas intenções, à falsa classe média lulista, gerada pelo modelo dos três Cs, Commodities, Crédito e Consumo. Até que uma nova tríade, o Governo de Washington, as Agências de Rating e a Mídia Anglo-Americana de Negócios, elevaram o Brasil à condição de "economia emergente". A consagração veio em 2009 com a capa da Economist, com o Cristo Redentor decolando, depois de ter obtido o grau mítico de investimento. Para ser exato, a promoção 
oficial teria ocorrido muito antes, em fins de 2002, quando Lula e FHC se uniram para conquistar o apoio de Bush (conforme enunciado no subtítulo do livro de Matias Spektor), recebendo em troca das garantias oferecidas o título oficial de "potencia emergente". Com mais de meio século de espera, a profecia do Manifesto Anticomunista de Walter Rostow se cumpria, finalmente o Brazil takes off segundo anunciava a mencionada reportagem de capa da Economist. Não estou sugerindo que esse upgrading seja imaginário, embora atenda a uma aspiração enraizada nas profundezas da selvagem inconstância da alma nacional, nem mesmo fruto do marketing geoeconômico, os investidores aliás dispensam o artifício. Há evidentemente lastro material para a internacionalização das empresas brasileiras e do Estado Logístico, como já se disse, que as monitora, e tudo mais que daí se segue em termos de reposicionamento internacional. Dentro da ordem, mas global player. A ironia de tudo isso é que a suposta decolagem do Brasil, o take off preconizado no início dos anos 60 por Rostow nos termos das teorias funcionalistas da modernização, devidamente rebatidas então pelas teorias críticas do subdesenvolvimento como uma condição histórico-estrutural e não resíduo tradicional de uma etapa a ser vencida por atualizações setorizadas, teria ocorrido algumas décadas depois, primeiro, depois do assim chamado colapso de sua modernização periférica - sei que o conceito de "modernização" é bem outro mas não posso discuti-lo aqui; segundo, depois do ajuste estrutural dos anos 90 que alavancou a dita internacionalização, iniciada de resto pela Ditadura mas só depois que o Golpe de 64 extirpou de vez qualquer alternativa histórica de acumulação que não fosse a da nova dependência, associada como se dizia na esquerda de então, conformada, dita es- querda, com os fatos da vida. Depois foi a apoteose mental que se viu, ainda mais retumbante nos círculos progressistas de esquerda, dentro e fora do governo. Compreende-se, quatro vitórias presidenciais consecutivas devem ter confirmado e reforçado sua velha, e hoje exclusiva da esquerda, fé no capitalismo, cujas contradições ainda fazem avançar a humanidade, como a China e a ascensão do resto estariam demonstrando. Quanto à direita, faz tempo que não acredita mais sequer na legitimidade da sua própria dominação, desconectou-se de vez.

Mas voltemos ao disparate totalmente contraintuitivo do enunciado mais geral do meu argumento: como diagnosticar uma época de expectativas decrescentes num momento em que o centro dinâmico da acumulação está se deslocando para o âmbito das economias emergentes, além do mais numa hora em que a hecatombe de 2008 parecia reforçar ainda mais a tese euforizante do descolamento dos países emergentes em relação à desaceleração dos centrais? Pior ainda, tamanho disparate filosófico acerca do tempo do mundo na hora histórica em que o futuro finalmente chegou para a periferia. E não um futuro qualquer, mas aquele mesmo entrevisto pelos clássicos da nossa tradição crítica, a construção nacional interrompida não só fora retomada mas estaria em vias de se completar. Não vou arrematar o disparate com o seu inverso, dizendo que não, embora sempre se possa observar que se o futuro chegou, também deveria ter chegado ao fim a chantagem neodesenvolvimentista com todos os seus corolários de segurança interna e assemelhados. Meu juízo não é em absoluto sobre a conjuntura macroeconômica ascendente dos latecomers, por isso tampouco teria qualquer cabimento aludir, com sinal trocado, aos últimos quatro anos de quase estagnação, ou ainda às armadilhas 
da famigerada doença holandesa, ou a da renda média, em que emergentes costumam atolar, etc. Há uns quinze anos atrás aliás até andei arriscando alguns palpites acerca da tese então em voga em alguns círculos acadêmicos europeus e americanos a respeito de uma presumida "brazilianização" do mundo, eufemismo pitoresco para a sensação de que os países centrais estavam se periferizando, mas na acepção antiga e negativa da expressão, conforme avançava o desmanche da sociedade salarial metropolitana, ou nos termos da resposta anterior, recuava a solidariedade social enquanto a sociedade se polarizava e despacificava, e o pensamento social, por sua vez, se concentrava no estudo do novo mal absoluto, a violência urbana. Pensando bem, o futuro chegou mesmo para todo mundo e, se assim é, deu-se uma verdadeira ruptura na relação "progressista" da política com o tempo. Esse o núcleo do meu argumento. No fundo uma tentativa de versão materialista da atual aceleração "presentista" da máquina capitalista do mundo: como quem não sobe cai, está todo mundo correndo embora não tenha mais para onde correr, por isso a unidade da medida temporal só pode ser a urgência. Regime no qual parece viver uma bomba relógio chamada China, cujo tic-tac pode ser ouvido em Chai-na (Otília Arantes), um livro sobre a maquina chinesa de crescimento urbano, descrita como uma esteira mecânica cuja aceleração alucinante parece consumir energias futuras esvaindo-se num aqui e agora sem fim. Sem falar é claro na outra unidade, o "valor", que não consegue medir grande coisa, mas tampouco vou dissertar sobre a tese da desproporcionalidade entre riqueza socialmente produzida e sua medida "mesquinha" e "miserável" pelo tempo de trabalho etc. Por certo um enorme etcetera, de uma fração do qual tentei me ocupar. Meu juízo é político, e certamente não pode deixar de levar em conta os efeitos sociais do realinhamento geoeconômico provocado pelo consenso das commodities, sendo o principal deles a recomposição do mercado interno pelo consumo de massa. Nada a ver com política institucional ou coisa que o valha. Muito menos política de poder, mesmo nas suas variantes progressistas, desnecessário lembrar. Mas com a política enquanto dimensão fundamental de encaminhamento das expectativas humanas, como a definiu Greg Grandin estudando o Terror Branco na América Central dos anos 80, cujo propósito era justamente o de extirpar pelo horror qualquer arremedo de sonho incongruente com a mais dura e crua realidade. A luta política tal como a conhecemos tem a idade do capitalismo histórico enquanto sistema produtor de sociedades orientadas compulsivamente para o futuro, no entanto reconduzido não menos coercitivamente ao presente como o limite que se almejava ultrapassar. Sem esse impulso que também podemos chamar de emancipação, a política é mera gestão de recursos de poder, administração técnica do presente. Acontece que o presente de agora não é qualquer, um presente no qual o futuro já chegou, e que tende por um lado a se perenizar como conjuntura sem fim, mas por outro, a se tornar cada vez mais politicamente explosivo, tal a sobrecarga de expectativas que vão se acumulando sobre ele em regime de urgência. Daí a importância estratégica do sonho, que o lulismo não por acaso se esmerou em colonizar, privatizar e confinar no devaneio aquisitivo, ao contrario do varguismo, que canalizou o sonho dos sem propriedade para o assalariamento com carteira assinada. Para se reinventar, e reinventar como antipolítica, numa era em que não se espera mais nada salvo o pior, a esquerda precisa saber reinterpretar os sonhos com que poderia estar sonhando 
o povo pobre trabalhador brasileiro. Um bom começo seria imaginar por onde andam os sonhos diurnos que permitem escapar da infelicidade coletiva da massa urbana comprimida no transporte diário de mão única, ida e volta, trabalho precário, moradia pior. Refletindo sobre os ônibus queimados nas Jornadas de Junho, o sociólogo e estudioso da construção da sociedade brasileira do trabalho, Adalberto Cardoso, certamente andou pensando no assunto. No limite, saber a quantas anda, a esta altura de nossa "emergência", combinada com horizontes de espera cada vez mais rebaixados, as metamorfoses da utopia brasileira por excelência, a do trabalho, a um tempo despertada e falsificada como fonte de legitimação da desigualdade durante a Era Vargas. Mais próximo do estado de emergência contemporâneo em que passamos a viver não faz uma geração, ou melhor no nervo mesmo da questão, encontra-se o argumento desenvolvido por Jonathan Crary sobre os fins do sono no turbo-capitalismo de agora. Girando num ritmo 24/7, seu objetivo estratégico é a criação do soldado sem sono, por sua vez precursor do trabalhador sem sono e do consumidor idem. Estes dois últimos sem dúvida há muito tempo produzidos e sobretudo conduzidos no inferno urbano das megacidades brasileiras. Sua equação não poderia ser mais direta: é verossímil supor que a imaginação de um mundo sem capitalismo principie como um sonho noturno na medida mesma em que a inércia restauradora do sono é um entrave a toda a letalidade da acumulação, pois até prova em contrário nenhum valor ainda pode ser extraído do sono.

Tudo isso dito, ainda não respondi por extenso a pergunta pelo prazo de validade da expansão da periferia dita emergente. São modernizações pós-colapso que ofuscam até mesmo espíritos críticos como Raul Zibechi, que ainda em março de 2012 considerava o Brasil um dos poucos países no mundo que estava escapando de sua condição periférica, dispondo inclusive da vontade política para tanto, sobretudo desde que tal enteléquia encarnou em um líder carismático, não descartando por certo, era só o que faltava, a percepção mais provável de que tal upgrading se dê às custas dos setores populares, seus e dos vizinhos. No ar, o voto piedoso inspirado por Giovanni Arrighi, primeiro que a ascensão pacífica da China abrirá espaço para os demais países emergirem num concerto político menos polarizado pelas hierarquias centro-periferia; segundo, que essa redistribuição do poder global acarrete o fim do capitalismo tal como historicamente o conhecemos. Livros recentes, cuja sequência pitoresca de títulos homólogos alguma coisa anuncia, como Ecuador made in China e Brasil made in China, não só desarrumam esse quadro sob medida para os novos progressismos do século XXI latino-americano e sua decantada terceira transição hegemônica, como lançam nova luz, sobretudo o segundo deles, sobre toda a reconfiguração do capitalismo contemporâneo, inclusive espacial, quando o mundo passa literalmente a ser fabricado na China, além de sugado pela proliferação das megacidades asiáticas. A constatação que se impõe é que o metabolismo do planeta "made in China" revirou pelo avesso a antiga era espacial dos tempos da Guerra Fria, em que os campos opostos simplesmente se justapunham e repeliam como comportamentos estanques de segurança mutuamente assegurada pelo terror nuclear. Hoje, com o Brasil dentro da China e a China dentro do Brasil, para retomar a argumentação do livro mencionado, tudo sugere que ingressamos num novo capitalismo de fronteira, com tudo o que isto indica de redefinição e controle dos territórios, governo das populações 
demarcadas segundo critérios estratégicos de projeção de poder, e consequente descarte dos retardatários. Todavia, pensando bem, acho que a dúvida legítima sobre essas decolagens emergentes ainda são tributárias de um tempo do mundo em que o mito da convergência entre centro e periferia, não um mito qualquer mas inerente à geocultura mesma de legitimação do capitalismo histórico, ainda por assim dizer funcionava, tanto assim que também funcionava a ansiedade quanto ao seu desfecho catastrófico. Um exemplo dessa imaginação retrospectiva. A certa altura do livro Chai-na ao qual aludi, um economista chinês baseado nos Estados Unidos, no MIT para ser exato, se pergunta, diante da grande eloquência do skyline de Xangai, o que há de errado com esse modelo de crescimento, para responder imaginando historiadores do futuro contemplando aquelas imagens de arranha-céus brotando dos antigos arrozais de Pudong como outros tantos sinais de alarme que ninguém quis ver, e arrematando sua profecia por uma analogia singular: nada mais parecido com o consenso de Xangai que comandava a China de Yang Zemin do que o "desenvolvimentismo" na América Latina dos anos 1970 a começar pelo gigantismo dos seus anéis burocráticos de negócios.

Na América do Sul, a última década foi caracterizada por uma série de vitórias eleitorais da esquerda, um ciclo que parece continuar com as recentes reeleições ou vitória de candidatos governistas. Em nosso chão, muitos intelectuais que apoiam o governo apostaram numa guinada à esquerda depois da vitória eleitoral, mas as primeiras mudanças no governo não parecem indicar isso. Você enxerga a possibilidade dessa consolidação institucional das esquerdas latino-ameri- canas se tornar uma era de transformações ou elas foram capturadas pelo establishment?

Vamos ficar pelo Brasil. Não deixa de ter sua graça pensar na hipótese de uma captura da esquerda de governo por um establishment empenhadíssimo neste exato momento (fevereiro de 2015) em aplicar-lhe um solene pontapé de despedida sem ao menos uma carta de agradecimento pelos serviços prestados. Ao que parece, é rua mesmo, aliás em mais de um sentido. O bom senso recomendaria prolongar a agonia pelo regime de austeridade até seu desfecho natural em 2018. Mas não, tudo indica que estão preferindo a morte matada mesmo, claro que pelas vias legais, impedimento ou renúncia. Vai ver que estão acreditando mesmo que o ajuste funcionará a favor de um novo miniciclo de prosperidade e consumo que um líder carismático saberá traduzir numa quinta vitória eleitoral consecutiva. E assim sendo, estão apertando todos os parafusos, deixando a lógica da polarização assimétrica escalar. É forte a impressão de delírio nestes cálculos. Que somado à flagrante catatonia do governo, reforçam a sensação de que estão todos juntos caprichando no disparador que faltava para fazer desabar de vez a tempestade social e ambiental perfeita que está se armando sobre as grandes regiões metropolitanas do país. Sem descartar a hipótese de que talvez seja esse o propósito, tal estado de desconexão em que se encontram todos os "atores" concernidos por um processo em que os desastres diários se sucedem. Se a catástrofe é o modelo, na boa formulação de André Villar, não há motivo para muita surpresa. Mas a esta altura, em que a máquina eleitoral petista apenas venceu para ser melhor destroçada, em caso de sobrevida será apenas isso, sobrevida, a dúvida "era de transforma- 
ções" ou "captura", com a ressalva de que neste caso estaríamos na fase da "soltura”, assume uma feição puramente retrospectiva acerca do que poderia ter sido mas não foi. Durante estes últimos anos de governo lulopetista um dos exercícios prediletos da esquerda clássica tem sido a análise igualmente clássica da variação dos membros titulares e suplentes do bloco de poder de sempre, formado na última conjuntura (média? longa?) pela burguesia interna, repartida entre seus diversos setores, e o dito campo popular e suas camadas dirigentes. A vantagem desse jogo de Lego é que ele pode prosseguir indefinidamente, pois as classes e as frações de classe sempre estarão aí, bem como as cadeias produtivas de onde o valor é extraído e posteriormente disputado, como nos bons velhos tempos. Defenestrados hoje, de volta na próxima temporada, uma eterna questão de correlação de forças. E claro que a conjuntura global e regional, que até anteontem jogava ao nosso favor. O resto é esquerdismo, ou coisa pior. Como ficamos, tentações de ironia fácil à parte? Há hipóteses poderosas sobre a mesa. Todas elas a serem examinadas pelo retrovisor. Posso apenas evocá-las. A primeira e mais inovadora foi apresentada por Chico de Oliveira, mal iniciada a Era Lula, como se há de recordar, a tese do Ornitorrinco, emblema do monstrengo social em que o país estava se transformando desde que fora atropelado pelo salto descomunal das forças produtivas impulsionadas por uma Terceira Revolução Industrial, e Militar, seria útil acrescentar de saída. Depois de um "atraso de cem anos" para emparelharmos com a Segunda, para falarmos ainda no antigo dialeto da ansiedade desenvolvimentista pelo catching up, nos víamos empurrados de volta para o fim da fila. E depois do choque, o tiro de misericórdia, a onda subsequente de privatizações e desmontes variados.
A ironia do diagnóstico residia num desencontro histórico: a vitória eleitoral do Partido dos Trabalhadores se dera justamente no âmbito de uma sociedade precisamente derrotada, com extração selvagem de mais-valia no seio de uma classe trabalhadora que encolhia e se dessocializava. Se é verdade, como sugeriam há algum tempo atrás Leda Paulani e Christy Patto, que o sentido da industrialização da periferia brasileira, como outrora o sentido da colonização segundo Caio Prado, cuja matriz se completara com a Ditadura, era a conformação de uma economia industrial moderna suficientemente sólida para funcionar enfim como plataforma de valorização financeira de alcance global, não restaria a um projeto alternativo de poder, como o dos trabalhadores organizados em partido, outra opção que não encarasse a dominância financeira no regime de acumulação em vigor no mundo pós-fordista. Na opinião no seu tempo herética de Chico de Oliveira, nascera uma nova classe de poder, justaposta aos intelectuais-banqueiros tucanos, os gestores sindicais dos fundos de pensão das grandes estatais, canal privilegiado de acesso aos fundos públicos. Tudo isso é sabido e relembro apenas para destacar que desde a primeira hora nossa cabeça mais lúcida naquele momento descartava as trivialidades acerca de cooptação ou mesmo traição de classe. Daí a continuidade com o ciclo anterior, do qual nada foi revertido. Nem seria preciso. Contra o senso comum compartilhado por direita e esquerda acerca das privatizações na Era FHC, Sergio Lazzarini revelou um outro panorama: daquelas famigeradas privatizações surgiu aos poucos um capitalismo diferente, um capitalismo de laços e conexões relevantes muito semelhante ao crony capitalism asiático, do qual emergiu reforçado um ator privilegiado, o Estado, e à sua volta, os não menos onipresentes 
fundos de pensão. O mais bizarro nisso tudo é que a visão estratégica a respeito dessas redes e seus conectores remonta em larga medida a sindicalistas escolados no manejo dos regimes de previdência complementar. Radicalizando a tese, um estudo recente de Maurilio Botelho sugere que a nomenklatura lulista acredita seriamente no controle operário dos meios de produção, só que dessa vez, ao contrário do capitalismo de caserna e seu imaginário estatista fossilizado, através do controle acionário, como se o suporte material exato do tal projeto democrático popular só pudesse estar ancorado num real poder operário-financeiro. Como qualquer governo hoje, um governo de esquerda antes de tudo, pois se trata de fundos de pensão de trabalhadores afinal, só pode ser um governo do mercado financeiro, ainda mais no caso brasileiro, em que a acumulação financeira se dá prioritariamente na esfera estatal, com lembrava Chico desde o início. Por essa materialização da mais antiga assombração da direita brasileira, a de uma República Sindical, suplantada apenas pelo pavor de uma revolta haitiana dos escravos, ninguém esperava. Na sequência, João Bernardo falará em Capitalismo Sindical, em cujo âmbito uma classe trabalhadora precarizada mas nem por isso menos intensamente explorada, confrontaria um polo dominante dual, a burguesia proprietária e os seus gestores "populares”. Já no plano propriamente surreal das construções ideológicas, essas grandes manobras de conquista do poder foram representadas como um projeto de capitalismo popular de mercados domesticados e moralizados por esses novos agentes empreendedores infiltrados pela porta dos Fundos. Assim como o petismo reinventou no Brasil o governo do "social", o sindicalismo financeiro teria sido desenhado justamente para fechar a equação, não a de um poder qualquer mas a de um poder projetado a princípio, ainda que não formulado nesses termos, como uma original reprodução de uma sociedade cuja modernização abortara. Deu-se então o inusitado, uma recaída desenvolvimentista extemporânea, justamente sobre essa plataforma financeira-extrativista reforçada pelo metabolismo chinês do mundo, a casa de máquinas do nosso diferente capitalismo de laços, que ao ganhar escala com sua nova constelação de transnacionais provocou uma reviravolta verdadeiramente histórica, a meu ver uma retomada pela "esquerda", e só por ela, pois se trata de uma abominação para os herdeiros de uma direita secularmente desfibrada pela falta de vontade de poder (não estou exagerando nada, é só ler os textos de nossos formuladores geopolíticos), do velho desejo mítico de um país potência regional que remonta ao impulso original de duas ditaduras (1937 e 1964), cujo rejuvenescimento se deveria a uma espécie de abertura da elite de poder, basicamente forjada naquelas duas ocasiões de "exceção" à antiga, para o sangue novo do poder gestionário de uma classe social que Getúlio Vargas por assim dizer legalizara para melhor desbancar seus concorrentes socialistas. A Era Lula é a certidão de renascença desse projeto de poder nacional. Aparentemente fantasmagórico (é o que pensa a direita clássica ao ruminar seu horror atávico a esse bloco ressuscitado), pois se isso tudo for verossímil estamos simplesmente anunciando que o Ornitorrinco de 15 anos atrás nada mais é do que uma sorte de capitalismo de Estado reinventado. E que se configurou porque havia uma vaga que lhe fora reservada na atual fratura do mundo, atravessado de ponta a ponta pelo confronto entre várias formas nacionais de capitalismo de Estado e outras tantas de capitalismos corporativos igualmente sustentados por 
seus respectivos Estados Logísticos, como já se disse. Não é mais a Guerra Fria pois o capitalismo está por toda parte, mas funciona como se houvesse no horizonte algo como a barreira intransponível, salvo hecatombe, de uma destruição econômica mútua assegurada, basta imaginar o abraço de afogados entre Estados Unidos e China se estritamente beligerantes. Trata-se de uma guerra em que todos são parceiros. Penso que por esse ângulo a atual campanha de defenestração e destruição do petismo adquire nova luz. Possivelmente uma luz que mais ofusca do que esclarece, e aí recomeçamos o realejo dos projetos em disputa (argh!) com peças simetricamente distribuídas nas duas metades de um tabuleiro cuja natureza igual para todos é posta de lado por todos como um reles pano de fundo, no caso a corrida entre todos os "capitalismos" para saber quem chegará primeiro ao fim do jogo, o planeta ou a espécie. Um sintoma alarmante dessa Segunda Guerra Fria, por enquanto mero decalque das guerras culturais em curso desde o seu epicentro americano, mas também vice-versa, tais guerras culturais entre "esquerda" e "direita", entre "progressistas" e "conservadores" etc., nas quais evidências e fatos não importam mais (na constatação desalentada de um Paul Krugman), apenas o "código" que coloca tudo e qualquer coisa na sua caixa de ferramentas bélicas (se você é Tea Party ou assemelhado nativo, mudança climática é uma conspiração de vermelhos contra o American Way of Life, e se você é vermelho do Sul Global, idem ibidem, o aquecimento global é uma conspiração imperialista contra a decolagem dos emergentes), replicam ponto por ponto a fratura entre "modelos" de capitalismo em concorrência pela extração de valor até da abolição do sono, pois um dos sintomas mais eloquentes dessa "guerra do século XXI", repito, são os alinhamentos automáticos qualquer que seja a ficha a cair. Um exemplo recém saído do forno: sua vitória ainda não completara uma semana e o novo Ministro das Relações Exteriores do Syriza já tomava posição a favor da federalização da Ucrânia, por mera coincidência a mesma posição de Putin. Tampouco seus dirigentes escondiam sua admiração pela saída dita pós-neoliberal aberta pelos países "progressistas" da América Latina e ao declararem que as proporções dramáticas do desastre grego denunciam a persistência de uma verdadeira "crise humanitária" no país, acrescentam que a inspiração das políticas emergenciais pertinentes virão, em boa lógica, das políticas sociais adotadas naquele continente, incluindo por certo os regimes CCTs (Transferências Monetárias Condicionadas, na sigla em inglês), aliás desenhadas nos escritórios do Banco Mundial nos idos de 1990 para remediar os estragos do ajuste estrutural. Difícil saber até onde irão as simetrias com a antiga Guerra Fria de verdade, lembrando por exemplo que a Revolução dos Cravos foi barrada pela OTAN, dinheiro alemão interposto. Mas o Syriza ganhou justamente por manter os pés no chão, e no entanto o realinhamento foi instantâneo, restando ver qual "recurso natural" fará da Grécia uma economia emergente, para não falar na vontadezinha de potência. Estou divagando, mas a este ponto chegamos.

Como entender nessa história recente brasileira os governos do PT (Lula e Dilma), onde a ampliação de direitos em determinados setores e as políticas afirmativas convivem com os centros de controle high-techs e o exército intervindo em comunidades do Rio de Janeiro? 
Se por "ampliação de direitos" a pergunta se refere ao universo de proteções sociais asseguradas não só pela letra mas também pelo espírito mesmo da Constituição de 1988 e neles reconhece a inspiração originária dos programas sociais que ao longo dos anos Lula se distinguiram como best practices e assim foram exportados mundo afora então um princípio de resposta pode ser encontrado nas considerações de uma estudiosa como Sônia Fleury acerca da inquietante transmutação regressiva do "social". Sim aquele mesmo social substantivado que foi literalmente inventado pelos movimentos nos tempos indecisos da Transição, pois aquele social concebido em termos de direitos universais de "cidadania", como se começou a falar na época, foi aos poucos se metamorfoseando numa outra substância demandando gestão empresarial e, cada vez mais, também militarizada. Ainda não sabemos se o ovo da serpente estava lá, em todo caso uma involução, cuja curva descendente vai do social-direito ao social-segurança passando no meio do caminho pelo social-combate-à-pobreza. A eventual ampliação de direitos, para manter a frase que talvez corresponda a outra coisa, tornou-se basicamente uma questão de segurança, como o Desenvolvimento durante a Ditadura. A comparação não me parece arbitrária, sobretudo se pensarmos em nossa recaída desenvolvimentista, justamente contemporânea da reformulação do social que está nos ocupando. O mais interessante no roteiro de Sônia Fleury, que passo agora a comentar ainda mais livremente, é que esta progressão do Welfare ao Warfare, e não simples degenerescência, se dá por uma dinâmica interna, embora se apresente, para variar, como dois projetos em disputa pela ressignificação do social, culminando com a vitória das políticas focalizadas sobre as universalistas. Não é preciso remontar até a reviravolta no modo de produção capitalista que provocou a crise fiscal do Estado, pressão social irresistível que por sua vez levou à prevalência da repescagem seletiva dos mais vulneráveis, cuja destituição fora dramaticamente agravada pelas políticas de ajuste às novas condições expropriadoras inerentes ao regime de acumulação financeirizada, seja dito para simplificar, pois estamos falando também de finanças previdenciárias.

Resta então compreender a gênese da abordagem armada na gestão desse novo social nascido na fronteira entre Welfare e Warfare. Acho até que seria o caso de inverter o ângulo de ataque e perguntar se na origem esse novo social focalizado não seria ele mesmo uma figura recortada por uma outra racionalidade a caminho. Racionalidade de gestão na qual o militar e o empresarial seriam indiscerníveis. Mas voltemos ao roteiro de Sônia Fleury, que principia pela formação de uma institucionalidade oculta, um híbrido de duas portas operando nas brechas da lei, de sorte que interesses mercantis passaram a circular no interior de sistemas públicos universais desenhados originalmente pelo princípio da desmercantilização da proteção social. Seu ponto é a compreensão do momento de inflexão em que o espírito do social nascido nos anos 1980 vai se tornando letra constitucional morta à medida que à presumida provisão pública universal de serviços básicos como educação, saúde, transporte, moradia, saneamento etc., funções clássicas de legitimação dinamizadora da acumulação, e vice-versa, exercidas pelo Estado, traduzida então na linguagem dos direitos coletivos, sobrepõe-se uma outra definição destas mesmas prestações legitimadoras, porém reapresentadas na forma de um combate protetor, em nome da racionalização otimizadora dos regimes de alocação, sugerindo um claro 
endurecimento do braço social do Estado. Foi assim que, em meio ao nevoeiro de uma querela ideológica sobre direitos coletivos e responsabilidades individuais, um novo Welfare destinado ao alívio da pobreza acabou se impondo como gestão das necessidades de populações em situações de risco, e gestão mediante um dispositivo de governo das condutas no qual se reflete de corpo inteiro essa mutação na concepção do "social", os mecanismos de transferências condicionados de renda mínima, os mundialmente celebrados programas CCTs, já mencionados. Saltam aos olhos as afinidades entre esse regime de condições impositivas de acesso a prestações monetárias, um inequívoco mecanismo behaviorista de reforços e sanções destinado a moldar comportamentos econômicos responsáveis, com ramificações por todos os âmbitos sociais, da moradia à sexualidade, e o regime de macro-condicionalidades ao qual foram submetidas as economias traumatizadas pelo choque da dívida e da hiperinflação no momento de seu resgate pelos carteis de investidores e seus agentes disciplinadores multilaterais. Com perdão da repetição, volto ao meu exemplo de há pouco. A atual crise falimentar dos Estados endividados da periferia europeia mediterrânea, agravada pelo remédio arrasa-quarteirão da austeridade e seu conhecido cortejo de maldades, dos cortes previdenciários às privatizações selvagens, é um claro remake do clássico tratamento infligido às populações latino-americanas vinte anos atrás, por isso é tanto mais espantoso, volto a insistir, que tenha partido da esquerda radical vitoriosa agora na Grécia e não da Troika, a lembrança da mesma saída de emergência adotada por aqui, e vendida com sucesso por seus principais beneficiários políticos, justamente os programas focalizados nas vítimas mais clamorosas do ajuste, e se for mesmo como manda o figu- rino, podemos imaginar o grotesco das condicionalidades exigidas daquelas populações relapsas endividadas por viverem acima de sua real linha de pobreza! A moralização é inerente ao processo no seu conjunto, sanciona-se a imprevidência com a austeridade e condiciona-se o alívio da pena à aquisição das habilidades necessárias ao retorno ao jogo econômico, indiscutivelmente responsável este último. Se isto de fato ocorrer e o círculo do Bolsa Família Grega realmente se fechar, e além do mais pelas mãos do Syriza, não resta mesmo dúvida de que o mundo está mesmo se brasilianizando, ou o Sul, se tornando cada vez mais global, sendo neste caso específico demonstrado pelo fato, como sugeriu Lena Lavinas, de que o paradigma do Welfare do século XXI é mesmo o da pobreza focalizada, comprando-se as demais provisões no mercado. Nesse paradigma de governo da insegurança social exprime-se uma visão moral do mundo em que o social substantivado de ontem ressurge como um processo normalizador, e como se trata de desentortar comportamentos desviantes e recalcitrantes, o esforço exigido é o de um combate sem tréguas. O social tornou-se de fato uma guerra de todos os dias em defesa da sociedade, mas de uma sociedade vista agora como um sistema de riscos difusos e ameaças cujos focos precisam ser anulados preventivamente.

Aqui o ponto cego de toda a reviravolta que converteu o social em cabeça de ponte de uma guerra maior. Os alvos variam conforme a temporada: drogas, criminalidade, HIV, pobreza, miséria extrema, terrorismo, e o que mais vier pela frente, até a emissão de gases de efeito estufa, no caso de declaração de um estado de urgência planetário por algum poder soberano ainda não identificado mas que na hora final dará o ar de sua graça. Caso esse ponto cego seja identificado, volto a lembrar que muito provavelmente 
nele encontraremos a confluência de duas racionalidades de novo tipo, uma militar e outra gerencial-empresarial, e que o índice mais eloquente dessa conjunção na origem das políticas sociais focalizadas em sua apenas aparentemente aberrante convivência de parede meia com a gestão armada destas mesmas políticas de promoção social, "social work with guns", como se referem certos estudiosos à nova abordagem americana da contrainsurgência, como dizem por lá, vem a ser, tal sinal de nascença, nada mais nada menos do que o foco nas técnicas de targeting, expressão hoje de tal modo inflacionada que nos fez perder de vista sua etimologia peculiar, perdida ao que parece nalgum escaninho da história das armas e da guerra. Consta que antes de se tornar um verbo, como na fase final em torno da qual estamos girando, "targeting Welfare spending”, target referia-se ao nome comum para um escudo de pequeno porte, geralmente manejado por arqueiros, e de caráter portanto defensivo visando antes proteger do que atacar, como hoje as políticas sociais focalizadas, com o perdão do curto-circuito brutal, nem por isso menos elucidativo, só que agora se protege visando um alvo. Novamente um curto-circuito retrospectivamente bem lastreado, pois também consta que a dita proteção oferecida pelo artefato foi se transmudando até se cristalizar numa acepção ofensiva como uma atividade visando atingir, ou tomar e apoderar-se, um alvo relativamente distante. Nesta direção, alguém observou, fechando o argumento, que o simples ato de mirar, o nosso targeting em questão, já é em si mesmo um ato de violência, ainda que nenhum tiro venha a ser disparado em consequência. Público-alvo então é mera consequência, por sua vez letal, não sendo todavia espantoso que por contaminação até os movimentos sociais tenham adotado o jargão. Bem como políticas sociais focalizadas no fundo são proteções ameaçadoras, ao passo que ameaças de proteção conferem ao poder de polícia o engajamento enobrecedor de um trabalho social. Terminou-se punindo os pobres, para retomar a frase de Wacquant acerca da virada punitiva do capitalismo americano recentrado pela dessocialização do trabalho, porque no processo daquela reviravolta foram os primeiros "visados", e como quem se encontra na linha de tiro, na alça da mira. Maximizar um programa de assistência social "encorajando" os pobres mediante incentivos monetários, positivos ou negativos (como no caso do imposto de renda negativo de Milton Friedman), ou então desencorajando a acomodação com restrições, burocracia humilhante e condições de acesso proibitivas, tudo isso passou a entrar no pacote da focalização, originariamente americano. Encarceramento massivo, chacinas, ocupação militar de território, também conhecida como "pacificação", são outros tantos componentes desse dispositivo maior de governo que são as políticas de targeting, que podem igualmente apresentar uma face benigna de redução de danos, não obstante a espada de Dâmocles punitiva sobre a cabeça do público-alvo da vez.

Iríamos longe se redescobríssemos novas técnicas de targeting, alternadamente terapêuticas e letais, na formação dos vários cadastros nacionais em que atualmente se reparte e reunifica os cidadãos brasileiros de segunda classe. É claro que não conseguiria completar agora o argumento se, partindo da outra ponta, fosse identificando a generalização das operações de targeting conforme avançava a mencionada Revolução nos Assuntos Militares, que tornou tecnicamente possível incluir a guerra num continuum de intervenções destinadas a corrigir disfunções na ordem mundial sem precisar arriscar mais 
explodir o planeta para alterá-la, política de alvos seletivos que culminou nas kill lists operadas pelos Drones. Poderíamos, voltando a página, retomar a convivência disso tudo com as políticas públicas de ação afirmativa, mas aí poderia parecer humor de cadafalso. Fico devendo igualmente a outra perna do argumento, lembrar que a contaminação da gestão empresarial, que por sua vez contagiou não menos fatalmente os movimentos sociais, pela nova redefinição militar da realidade, não é uma via de mão única, que a Revolução nos assuntos militares não se resumiu exclusivamente à reviravolta high tech que se sabe, nem a processos típicos de desmonte dos grandes corpos armados tratados como plantas fordistas obsoletas, a começar pelo recrutamento da força de trabalho e sua banalização tecnológica em guerras ditas "pós-heroicas", embora exponencialmente brutalizadas no terreno, conforme se acentuava o caráter policial das operações militares de intervenção, etc. Mas um enorme etcetera. Resta o efeito dissonante, sobretudo no núcleo orgânico do sistema, de sociedades pós-militares (até mesmo a ideia de "serviço" militar desapareceu) em que é crescente a militarização da vida urbana, bem como forças armadas cada vez mais policializadas e polícias progressivamente planejadas e atuando manu militari. Na periferia emergente não é menor a dissonância, sua percepção valendo inclusive como indício seguro de divisor de águas, por exemplo, no caso brasileiro, demarcando as origens do Brasil Contemporâneo, um território a ser explorado com categorias novas, em ruptura com o progressismo congênito que nos definira desde sempre como uma comunidade de expectativas imaginadas, a última delas aliás a da "ampliação de direitos" que comparece pontualmente na pergunta que ainda estou tentando responder. É que por mais devastadoramente sanguinária que tenha sido, explicitando a associação violenta entre Desenvolvimento e Estado de Segurança Nacional, e por mais que aparelhasse militarmente as empresas estatais que foi multiplicando, a Ditadura jamais poderia ter se encaminhado para uma gestão armada da vida social. Quando muito poderíamos observar, a título de homenagem por assim dizer, que a atual visão terapêutica da polícia como operação pacificadora seria uma espécie de obra póstuma sua. $\mathrm{Na}$ verdade ela é uma continuação do viés punitivo assumido pelo Discurso dos Direitos Humanos em sua fase pós-utópica de rotinização como política pública, justamente implementada por um poder de Estado que se distingue pela violação sistemática de tais direitos. Não diria que isto já é outra conversa, pois se fosse um pouco mais esmiuçada nos devolveria, por exemplo na figura do Humanismo Militar, na expressão consagrada por Chomsky ao comentar a guerra de intervenção humanitária do Kosovo em 1999, ao subtexto da pergunta, um deles pelo menos: desde 1988 vivemos oficialmente num Estado Democrático de Direito, baseado e legitimado pelo consenso dos Direitos Humanos, não há desatinado que discorde e se coloque à margem, e no entanto, em nome da observância e proteção desses mesmos direitos assistimos a uma escalada punitiva jamais vista, ou melhor, não custa repetir, cada vez mais visível porém naturalizada, e demandada, na generalizada gestão coercitiva da vida social.

Disse que essa visão é consensual, entre outras coisas, por ter engolido a esquerda histórica, cuja memória registra a tal "ampliação de direitos", e a ser assim, devemos constatar que uma esquerda que não soube se reinventar numa idade em que as grades esperas ficaram para trás, quer dizer uma esquerda sem futuro, mas na antiga 
acepção do termo, só poderia mesmo se tornar ela própria punitiva, além de enjaulada pelo ordenamento jurídico. Daí a saída de emergência pelo targeting, que muitos teóricos não hesitariam em incluir entre os conceitos chave de um diagnóstico de época que considera a sociedade contemporânea de risco um sistema organizado não só para responsabilizar mas para agravar a sobrecarga das responsabilizações, cada vez menos a sociedade, cada vez mais, até o limite da autodestruição, o indivíduo. Como vimos, o princípio mesmo da dessolidarização social na qual a ultra-direita nada de braçadas, afinal só caem abaixo da linha de pobreza indivíduos que tomaram as decisões erradas. São eles então os clientes-alvo na mira dos programas de transferências condicionadas.

Acabamos de sugerir como a tecnologia da focalização, ao sublimar um inequívoco mecanismo distribuidor de prêmios e castigos, alimenta uma sorte de limbo coercitivo onde Welfare e Warfare terminam se encontrando. Que a direita tenha celebrado sua própria invenção, ainda que o sucesso do teste tenha ocorrido no laboratório latino-americano, é a evidência mesmo, afinal firmou-se a tendência a concentrar o gasto social nas transferências monetárias, de resto modestas na porcentagem do produto, em detrimento da oferta de bens públicos desmercantilizados, mas não deixa de ser um sinal dos tempos o fato esse sim espantoso de que a esquerda que os opera com reconhecida proficiência tenha saudado tal saída de emergência como uma conquista social, sinal de que o horizonte encolheu a zero mesmo. Mas sobretudo indicativo de que vistas as coisas pelo ângulo oposto, pelo prisma do alvo em pessoa, apanhado pela rede de um cadastro, o panorama se presta a uma outra celebração desse mesmo social no qual Sônia Fleury reconheceu tão somente uma nefasta transmutação regressiva das expectativas que madrugaram no início dos anos 1980. É que a invenção brasileira do "social" para remendar os "impasses do inorgânico" parece não ter limites. De sorte que um fim de linha bem administrado pode muito bem servir de plataforma de lançamento de um novo paradigma substitutivo da sociedade salarial que não aconteceu. Visto como uma "política de urgência moral” (Nancy Fraser), o Bolsa Família, na voz de seus beneficiários condicionais, pôde então ser redescrito como uma abordagem de "reconhecimento", porém sem luta obviamente, como mitigação do sofrimento social etc. Na outra ponta do targeting, a mesma visão moral só que com o sinal invertido, superlativamente positivador, encarado pelos gestores de toda operação como o limiar de uma inédita cidadania moral. Nenhuma alma naturalmente cristã dirá que não. Muito menos um ativista, no caso um trabalhador social impregnado pela cultura terapêutica da redução de danos, cuja cristalização é uma das marcas inaugurais do novo tempo presentista do mundo de que estamos falando desde o início. A própria compreensão dos Direitos Humanos como a última utopia (Samuel Moyn), de resto desfeita pelo esgotamento de sua energia fundadora, já é um marcador preciso dessa divisão histórica de águas. Exigir da gestão focalizada do povo pobre a liberação do acesso a uma porta de saída é uma expectativa de outros tempos, de sociedades que o capitalismo de antes do colapso de sua fome canina por trabalho vivo orientara para o futuro. A dívida social herdada, que sempre pesou na consciência progressista nacional, passou a ser filtrada por um outro código, "presentista" volto a repisar, o mesmo que presidiu a rotação da agenda de esquerda em busca de justiça social para um passado de graves violações, anulando juridicamente 
o tempo histórico na figura do crime imprescritível. Há uma equivalência de época entre os parâmetros da Justiça de Transição e os Programas Sociais por CCTs, ambos são dispositivos regidos por uma análoga tecnologia de targeting, ambos envolvem traumatismos históricos recolhidos pela lógica individualizadora da responsabilização. E da reparação. Este o ponto de virada. O Repare Bem (título de filme de Maria de Medeiros sobre a vida, paixão e morte de Eduardo Leite, o Bacuri) vale tanto para os supliciados, mortos e desaparecidos da ditadura (ou do Terceiro Reich) quanto para os humilhados, ofendidos e esbulhados da história social brasileira (ou os massacrados da Conquista e da Colonização), e para todos vale o mesmo princípio do tempo político zerado pela indenização em dinheiro. Isso mesmo, o Bolsa Família e assemelhados no Welfare do século XXI integram sim a grande galáxia presentista das políticas de reparação. Por isso a presença do dinheiro não é trivial nessa gramática moral do reconhecimento. Acrescentar que é funcional, vistas as coisas do ângulo do regime de acumulação sob dominância financeira, é por certo necessário, mas não o suficiente para apreender em toda sua surpreendente e nova singularidade a época em que a ruptura da anterior nos precipitou, a ratoeira do contemporâneo. Entre as novidades de época, o fato de que todo esse bizarro Sistema da Dívida se apresenta invariavelmente na forma tribunal. Que cedo ou tarde acabará transmitindo o vírus punitivo. Daí também o efeito paradoxal das políticas de reparação focalizadas. A expressão odiosa Bolsa Ditadura tem a mesma raiz tóxica da sanha conservadora, todas as classes sociais confundidas, do ímpeto assassino com que se costuma atacar os incorrigíveis e irrecuperáveis "alvos" justa- mente daquelas políticas. Um contra-ataque penal, pois não se consegue imaginar outra saída da dita ratoeira senão as emergenciais, porém já cronificadas. Seria portanto um enorme cqd.

Em alguns debates você aponta o Estado do Bem-estar Social do pós-guerra como o resultado de uma correlação de forças construída entre esquerda e direita - no caso da Europa, principalmente como o resultado da resistência contra o fascismo. Contudo, muitos autores partem da crítica da economia política para argumentar que esses direitos fazem parte da necessidade estrutural capitalista de expandir o mercado e abarcar quase todos os domínios sociais com a forma mercadoria. É possível mediar essa explicação estrutural com a conjuntura política?

Está claro que não desconheço e muito menos desconsidero as análises originais do James O’Connor e Claus Offe, para ficar nos mais conhecidos, acerca das funções básicas do Estado Capitalista. Acumulação e legitimação, segundo O'Connor. Uma estratégia geral envolvendo ordens, proibições e incentivos destinados a criar e assegurar as condições para que todos os sujeitos jurídicos sejam incluídos nas relações de troca de equivalentes de modo a evitar a descaracterização como mercadoria de todas as unidades de valor engajadas no processo, segundo Offe. E como poderia? Além de representar um auge na crítica da economia política do Estado, são por assim dizer do meu tempo. Ambos foram publicados e lidos no Brasil na virada dos anos 1970 para os 1980, justamente num momento em que o fim da miragem do fordismo periférico nos precipitava igualmente num cipoal inextricável de demandas 
particularistas, como O'Connor descrevia a Crise Fiscal do Estado, americano no caso. O próprio Offe andou por aqui em 1982. Alguma pesquisa e um certo esforço de memória poderiam rastrear muita coisa para a recapitulação de agora, pois afinal faz tempo que a mágica da legitimação pela acumulação se desfez, se é que alguém ainda se lembra, socialmente falando, daquelas três décadas do pós-guerra em que a estratégia estatal de fazer funcionar o processo de acumulação era ao mesmo tempo resolver a questão social, no bom resumo de Javier Blank, num artigo recente. Hoje, o Welfare do século XXI é bem outro, em que termos, acabamos de evocar. Pois naquele momento de crise funcional do Estado Keynesiano de Bem-Estar no núcleo orgânico do sistema, e de colapso da modernização periférica, era tal a confiança por estas paragens naquela "dialética" da crise estrutural do Estado Capitalista, muito enfatizada, por exemplo, nos esquemas de Offe, segundo os quais a cada tentativa de reincorporação de unidades de valor ao núcleo produtivo e "apaziguador" do sistema, concebido para isso mesmo, tornar o assalariamento aceitável e desejável, multiplicavam-se as esferas de "bens públicos" que escapavam à incorporação aos circuitos da troca mercantil, que ocorreu a mais de uma cabeça pensante da esquerda mais avançada da hora estarmos na antessala do socialismo... Com os "fundos públicos" ao alcance da mão popular que ajudara a Ditadura a passar desta para melhor. Como ainda valia a pena sonhar com a hipótese do antivalor, segundo Chico de Oliveira, não só parecia plausível como se apostava, na contramão da tese da funcionalidade de um jogo de soma positiva, cada classe assumindo o papel da outra classe, como se dizia na língua do consenso keynesiano, no antagonismo entre bem-estar e capitalismo, enfim na contradição por certo disfuncional de um sistema econômico que utiliza força de trabalho "como se ela fosse uma mercadoria" (parece Polanyi mas é Claus Offe) necessitar como estrutura de apoio um conjunto de instituições não-mercantilizadas. Ainda Claus Offe, envenenando o jogo do contente Welfare State Keynesiano, mas já estava declarada a sua falência. Na hora $\mathrm{H}$, em que a esquerda planejava dar o pulo do gato... faltou dinheiro, secou a fonte do financiamento. Nesse momento principiou nosso imbróglio particular em torno do que se pode chamar de demanda de Estado, que aliás no Brasil tem uma genealogia singular, não custa observar, pois se trata paradoxalmente de um Estado congenitamente exterminador de sua população desclassificada, até que Getúlio inverteu a percepção, mas só a percepção. Quer dizer, à esquerda principiou nossa regressão. Naquela imagem da disfuncionalidade funcional do Estado de Bem-Estar restou apenas isso, a imagem congelada de um fim em si mesmo, noves fora suas circunstancias europeias de nascimento, por exemplo, de que logo falaremos, na fórmula precisa de Marildo Menegat, "a ilusão da revolução sem que esta tenha ocorrido". Isto na Europa, imaginemos por aqui. A esquerda que se reinventara depois da Ditadura, criando por assim dizer do nada o "social", passou a considerar o Estado ora como uma agência processadora de políticas públicas de acordo com o jogo poliárquico de pressões e contrapressões, ora como o locus em que demandas de classe disputam sua direção neste ou naquele sentido, conforme a famigerada correlação de forças, ora mais burguês, ora mais popular, uma espécie de joão-bobo em suma. Nem traço na memória política daquela encruzilhada pelo menos teórica da década de 1980. Como restou suspensa no ar a imagem redentora do Estado Social produtor por geração 
espontânea de bens públicos, sempre que se quer desancar ou celebrar o que restou da dita esquerda, costuma-se denegri-la ou enaltecê-la identificando-a à social-democracia europeia, à qual se costuma atribuir o parto do Estado Social que ascendeu aos céus durante os 30 gloriosos. É nesse momento que nos debates, para melhor destacar a originalidade nativa do lulopetismo, costumo contrapor a tal fantasia o "traumatismo" europeu do referido parto, um complexo de revoluções, guerra e fascismo burguês, se é que se pode falar assim. O próprio Claus Offe, quando se refere às origens ideológicas muito heterogêneas do Welfare State que começou a se consolidar no imediato pós-guerra não dá maiores precisões nem refere a circunstância maior, o trauma da guerra contra o fascismo. Para início de conversa, é lugar comum na historiografia europeia e americana do norte constatar que a expansão dos direitos dos cidadãos perante o Estado se deve à força propulsora das guerras da nação. Nem sombra disso na periferia latino-americana: na observação de Charles Tilly, por exemplo, que atribuiu como se sabe a formação dos Estados europeus à operação conjunta de dois macrofatores autônomos, coerção e capital, os latinoamericanos sofreram os horrores da repressão do Estado a bem dizer porque foram poupados dos horrores da guerra internacional de grande escala. Nada mais clássico, digamos assim, do que a pensão do veterano de guerra. Para resumir um pouco a minha ópera, revistas as coisas com mais de meio século de distância, relembro de passagem um artigo dos anos 1980 do mesmo Charles Tilly sobre a prática da guerra e a criação do Estado como Crime Organizado, enfim um problema de compra e venda de proteção em que Estados e criminosos organizados extraem um excedente do próprio excedente, e como hoje em dia está cada vez mais complicado distinguir entre guerreiros, bandidos e governantes, e não apenas no Rio de Janeiro. A começar pelo Estado Islâmico, amostras contemporâneas é que não faltam.

Mas voltemos a meu ponto de partida europeu, francês no caso, afinal eles inventaram o "social" em meados do século XIX. Acossados pelos traumas sucessivos de 1848 e da Comuna de Paris, saíram à procura de um dispositivo capaz de proteger o trabalho contra as investidas do patrimônio, até então o único a propiciar segurança (Donzelot). Dito isso, meu juízo vinculando a inegável funcionalidade do Estado Social reconstruído na saída da guerra à ameaça antissistêmica de uma reviravolta revolucionária na esteira da vitória da aliança antifascista em 1945, precisa evidentemente ser calibrado. E no limite, revisto à luz do novo entrelaçamento entre Welfare e Warfare inaugurado justamente naquela conjuntura nova que se abria, a da Guerra Fria que arrematava a Guerra de Trinta Anos iniciada entre 1914 e 1917 como uma guerra civil europeia (Isaac Deutcher, Arno Mayer, etc.), como de uma vez por todas deixara claro o laboratório da Guerra Civil Espanhola, incluído no experimento o terror exercido pelo poder contrainsurgente soviético-stalinista. Pois então. A experiência paradoxal de fundo naquele curto intervalo, espécie de terra de ninguém histórica entre dois fronts era novamente a de um outro ciclo de Great Expectations impulsionadas pelo choque de uma catástrofe social jamais vista. Esse o terreno em que prosperou a última miragem progressista da era histórica que começaria a se encerrar nos anos 1970 com a desativação do mecanismo "miraculoso" de retroalimentação das funções básicas de acumulação e legitimação exercida pelo Estado capitalista, como Javier Blank condensa o argumento de James O’Connor. 
No âmago de tudo aquilo todavia, a percepção da função utópica da Resistência, a dimensão prefiguradora extraída de sua experiência dos extremos sob a Ocupação. Para se ter uma ideia dessa dimensão de utopia vivida como antecipação, posso apenas remeter ao paradoxo do enunciado de Sartre na República do Silêncio, "nunca fomos tão livres como durante a Ocupação", ou as não menos famosas anotações de René Char sobre aqueles anos essenciais em que o colapso da França permitira desenterrar o tesouro perdido das revoluções, na frase do comentário bem conhecido de Hannah Arendt que eu obviamente não vou dissecar. Para os movimentos de Resistência estava fora de cogitação voltar ao estado de coisas anterior a uma guerra que precisamente nada mais era do que a fuga para frente catastrófica destinada a perpetuar o dito estado de coisas. A Revolução esteve no ar na forma daquela "oportunidade antifascista". Como sabemos desmanchou-se nesse mesmo ar em pouco tempo, houve até guerra civil (na Grécia, por exemplo), mas a Revolução não veio. Seu modelo eram os Comitês Populares da Resistência, na opinião de um historiador (Geoff Eley), formas moleculares de um caminho imaginado à imagem e semelhança dos conselhos de trabalhadores que se espalharam pela Europa entre 1917 e 1921, novas formas de participação popular equivalentes à atividade da resistência, reconstruir a sociedade nos moldes igualitários da emergência de guerra no seu final etc. Ocorre que ao terminar a guerra a Europa já estava sob uma nova Ocupação, desta vez pelas forças militares aliadas. Uma insurreição da militância armada dos partigiani italianos, por exemplo, seria fatalmente dizimada, e certamente com a aquiescência soviética. A rigor, ao sopro utópico do primeiro tempo da Libertação respondeu uma nova Restauração. Nova porque o grande estouro da Libertação a fizera engolir o sucedâneo de uma Revolução que não houve, justamente o Estado Social. Daí a sua funcionalidade de mão-dupla. Assim, já durante a guerra, a cada derrota eleitoral dos conservadores, Churchill anunciava que um verdadeiro Welfare State estaria a caminho coroando o esforço de guerra da nação com proteção e segurança do berço ao túmulo. Na França, o Governo Provisório criou em 1945 a Seguridade Social tal como constava no programa do Conselho Nacional da Resistência. Combinaram-se assim uma irresistível (ou melhor, resistível afinal) pressão popular vinda de todas as mobilizações de energia social para guerra e as grandes manobras do alto comando do poder capitalista vitorioso numa resultante bifronte, um sistema de segurança social cuja gestão confiscada pelas novas burocracias racionalizadas durante a guerra anunciava que estávamos ingressando numa nova era sim, uma era de populações administradas, aliás "totalmente", se é fato que à Guerra Total estava dando sequência uma Paz Total, como Paul Virilio preferia chamar a Guerra Fria. Cujo documento de fundação seria o Relatório Beveridge de 1942, nada mais nada menos do que um programa de Seguro Social desenhado pelos Serviços Aliados, em vista da "vida saudável" do cidadão a ser aliviado do fardo maior das necessidades elementares. Neste sentido, não se poderia "documentar" com mais propriedade a ideia, à primeira vista incongruente, de que desde o seu nascedouro um sistema de garantias e provisões sociais na verdade era um plano de guerra, mais exatamente, concebido para se ganhar uma guerra, e continuar vencendo a seguinte. Como Marcuse fará a prova ao descrever nos idos de 1960 a racionalidade tecnológica da dominação nas sociedades industriais avançadas, como se dizia então, analisando justamente a pioneira confluência americana de Welfare 
e Warfare, a saber, que a vida totalmente mobilizada por um estado permanente de prontidão militar cataclísmica é ao mesmo tempo uma vida totalmente mobilizada pela produção propriamente dita e seu aparato latu senso de prosperidade e bem estar. Com isso descobria de quebra a anomalia que o materialismo histórico não previra: uma simbiose tal entre forças produtivas e relações sociais de produção que o desenvolvimento proverbial e exponencial, das primeiras, ao invés de revelar o fundamento opressivo das segundas, torna-se fonte perene de legitimação do sistema. Para o Marcuse materialista era essa a mais espantosa novidade histórica, uma sociedade unidimensional, sem oposição interna e por isso mesmo em movimento perpétuo ao redor de um mesmo centro imóvel impulsionado pela combinação produtivista de bem estar e guerra. Dez anos antes, à equação de James O'Connor entre acumulação e legitimação Marcuse acrescentava um termo médio, na verdade sua condição de possibilidade, como gostam de dizer os filósofos, o sistema das armas, mais exatamente o sistema das armas nucleares, só que desta vez nada menos do que a banalização de uma ameaça catastrófica como rubrica orçamentária. O olho para enormidades deste tipo é o que talvez singularize a percepção de Marcuse, no fundo de acordo, presumo pois nada mais sei a respeito, com o diagnóstico de O'Connor acerca da dinâmica paralela de Previdência Social e Complexo Industrial-Militar. A meu ver um argumento decisivo para que passemos a considerar o sistema de vasos comunicantes entre as formas da guerra e as sucessivas reconfigurações do Estado Social. Conforme os tempos de reforço mútuo entre acumulação e legitimação foram ficando para traz, e com ele o dispositivo de gestão social em vigor durante a "paz total" da Guerra Fria, tornou-se cada vez mais nítida uma das evidências do nosso tempo, o continuum de segurança ligando, entre tantos outros pontos de vulnerabilidade a securitizar, conforme o jargão, as novas formas predominantes das guerras de intervenção nas bordas do mundo e o Welfare focalizado cuja estratégia bélica de targeting ressaltamos lá atrás.

Você reconheceu a inspiração no livro de Christopher Lasch, A Cultura do Narcisismo, que fala da "Vida Americana numa Era de Esperanças em Declínio". Em um trecho do livro, Lasch aponta que uma das características de uma era em que a política se tornou espetáculo é a "a arte do controle de crises". A irrupção de crises que não são meros recursos de propaganda política-se tornou funcional ao controle social?

Para ser sincero, nunca tinha visto o argumento de Christopher Lasch sobre a cultura no narcisismo por esse ângulo da política como espetáculo, mais exatamente e por extenso, como a arte de criar nos espectadores do dito espetáculo uma crônica sensação de crise, percepção que por sua vez justificaria não só a expansão do poder executivo (estamos falando basicamente dos Estados Unidos, onde tal poder é elástico no limite dos plenos poderes, como exigido pelos pais fundadores à imagem e semelhança das regalias de Napoleão Bonaparte depois do Dezoito Brumário) e dos segredos que o cercam, como os revelados por Daniel Ellsberg (aliás citado por Lasch duas páginas depois de sua definição da política como arte do controle de crises), o analista da CIA que em 1971 vazara para a imprensa os papeis do Pentágono documentando o envolvimento norte-americano na Indochina de 1945 a 1968, um rosário das mais tenebrosas covert operations como hoje é fácil imaginar. Para ser ainda mais sincero, 
vejo marcas de leitura no meu exemplar brasileiro de 1983 (o original é de 1979), e no entanto não me lembrava de mais nada, até que a pergunta de agora me obrigou a ir atrás. Logo darei minhas impressões póstumas. Antes preciso esclarecer que minha "inspiração", embora decisiva pela fórmula a meu ver mais do que exata como diagnóstico de época, precisamente uma "era de expectativas [Expectations] diminuídas", restringiu-se a uma interpretação muito livre deste subtítulo do primeiro livro e outras tantas variações em torno do tema da vida cotidiana como um exercício de sobrevivência, desde que as pessoas, vivendo um dia de cada vez, passaram a preparar-se para o pior, uma vida, psíquica em primeiro lugar mas não só, em situação de sítio, a mentalidade sitiada que o livro subsequente irá explorar e reconhecer de passagem sua contaminação também pelos movimentos de oposição na época, como os pacifistas e preservacionistas (como eram chamados os ambientalistas), cujo inegável sobrevivencialismo rimava, em seu núcleo igualmente defensivo, com as estratégias de segurança nacional concebidas para sobreviver a uma guerra nuclear. Essa a passagem inaugural acerca da Emergência como época histórica que me interessava começar a identificar. Com uma diferença, fácil de destacar uma vez relido o material pioneiro de Lasch trinta anos depois, se estou no rumo certo. É que todo aquele conjunto de sintomas eram encarados como uma patologia regressiva atribuída a um surpreendente enfraquecimento do sentido do tempo histórico e correspondente falta de confiança no futuro, juízo que na década seguinte se tornaria uma espécie de marca registrada da esquerda cultural anglo-americana toda vez que se manifestava lamentando uma época que tinha esquecido como pensar historicamente, para denunciar uma perda, uma atrofia, uma extinção enfim do senso da história, para cuja temporalidade deveríamos desesperadamente despertar uma outra vez. Não direi que não, até porque foi exatamente isso que ocorreu, mais um fim ou mutação que seja, esgotou-se a temporalização da história (Koseleck), tal como a conhecíamos, aquela distância até então impensável que se abriu entre a experiência passada e filtrada e um mundo por vir num horizonte de possibilidades deultrapassagem, ou, justamente, retrocesso bárbaro. Simplesmente e com H maiúsculo, a história deixou de ser a evidência inapelável que foi durante dois séculos, um longo (1979-1914), outro curto (1914-1989). Não, não é Fukuyama não. Outrora o espantalho favorito do senso comum progressista, que deveria ter percebido (mas como?) que aquela visão nada ingênua do fim da história, a rigor era o primeiro capítulo de um novo Discurso da Guerra. Do qual não vou tentar agora é claro expor e periodizar sua economia política, que espero ter deixado mais do que subentendida nas respostas anteriores. A expectativa zerada é outra coisa, ou melhor, outro tempo, cuja unidade de medida é a urgência, e o centro de gravidade, um presente expandido para frente e para trás sob o signo da proliferação de estados de emergência cuja índole securitária ou libertária não está decidida de antemão. Lasch mapeou a primeira cristalização dessa sensibilidade terapêutica. Seu desenho no entanto tinha como bastidor o sentimento de que a resposta política desejável em algum momento deveria reatar com a ebulição dos anos de resistência à Guerra do Vietnã, por exemplo, cujo radicalismo todavia ele mesmo não deixava de desancar como teatro de rua. Depois veio o sobrevivencialismo para todos, esquerda e direita. Hoje há uma nova epidemia sobrevivencialista nos Estados Unidos, com nichos de mercado 
próprios, ideólogos militarizados, núcleos organizados e armados, inimigos recrutados na imprevidência geral, além dos suspeitos de sempre; nova disseminação que está assumindo proporções de movimento social, todos os seus "ativistas" empenhados na preparação da travessia de uma Longa Emergência, como se lê no título de um livro de recomendações a respeito do colapso vindouro. Esse o leite derramado pelo qual não adianta mais nada chorar, o leite de um tempo em que a luta de classes parecia civilizar o capital. A política agora é a da ambulância, da redução de danos, se benevolente, do mal menor, se gestão dura do efeito colateral (aliás, no discurso social da esquerda brasileira, o termo "colateral" acabou substantivado, por exemplo, quando se diz que a política social "é um colateral" garantido pelo Estado, um anglicismo talvez), seu paradigma só pode ser a medicina de urgência, que o digam os ativistas pioneiros dos Médicos Sem Fronteiras. A objeção progressista de que a dramatização da conjuntura é mera gesticulação compensatória da perspectiva transformadora rifada, simplesmente arromba a porta aberta da evidência maior do nosso tempo, a saber, que a decomposição da sociedade capitalista a rigor não anuncia mais nada, quer dizer, mais nada daquelas velhas coisas boas de sempre. Já o novo ruim do qual é preciso partir só pode ser algum análogo da expectativa máxima de outrora rebatida sobre o presente. Em resumo, o diagnóstico de Lasch segundo o qual passamos a viver numa era de expectativas diminuídas, que também presumo certeiro em todos os seus desdobramentos vindouros, não exprime todavia, como ele mesmo dá a entender, uma perspectiva reversível e por isso mesmo não se trata de um equívoco político ou ideológico, um caso solucionável de falsa consciência ou erro filosófico etc. Noutras pala- vras, Lasch anunciava um novo tempo de olhos voltados para o anterior, que tampouco pareceu compreender em sua dimensão profética. Pensando bem, chegou bem perto de decifrar a charada. Sua página de abertura é reveladora, uma intuição luminosa que infelizmente não desenvolve. A ideia, que foi buscar num livro do crítico literário Frank Kermode, segundo a qual, com algum exagero, e outras liberdades de minha parte, no âmago "modernista" da Arte Moderna, se é que se pode falar assim, reside uma sorte de sexto sentido congênito para o "fim", um certo senso apocalíptico para a queda, ou a antevisão da ruína, como na iluminação baudelairiana da Paris novinha em folha de Haussmann precocemente entrevista na forma de escombros anunciados, sendo que tais visões proféticas da desgraça não decorriam somente das premonições próprias das vanguardas ditas históricas acerca do horror que se avizinhava na forma de uma guerra mundial, como no caso do Expressionismo, mas se alastravam igualmente até os espíritos mais pacatos e conformistas, como na dúvida de um T. S. Eliot acerca do fim do mundo, se com um estrondo ou um soluço. Pois bem, Christopher Lasch remontou até aquele auge de projeções estéticas do "fim", características da sensibilidade modernista, na exata medida aliás em que toda criação artística, segundo Valéry, é a criação de uma espera, um momento superlativo de expectativas em torno de um desenlace conclusivo, para melhor descobri-lo atuante na imaginação popular desse tempo limiar que estamos procurando identificar e que ele, Lasch, foi um dos primeiros a discernir como um rebaixamento paradoxal de horizonte, ao notar que no repertório pop composto de memórias industrializadas ou não do Holocausto, ameaça de aniquilamento nuclear, esgotamento de recursos naturais, pre- 
dições de desastre ecológico, aquelas profecias estéticas encontraram enfim um lastro de confirmação social inusitada. Do mesmo modo, vinte anos depois, a primeira providência de Mike Davis diante do entulho ainda fumegante do 11 de Setembro, foi escavar menos no lixão dos óbvios filmes-catástrofe hollywoodianos, a memória sismográfica da arte moderna até se deparar com a incrível recorrência de imagens exprimindo o pesadelo ou sonho com o skyline de Manhattan em chamas, para não falar é claro na Elegia do nosso Drummond. Aqui por certo há coisa a explorar, mas não quero abusar, salvo resumir tudo relembrando pela enésima vez a observação de Benjamin acerca da natureza por assim dizer agônica do tempo moderno, um tempo de espera por excelência, de sorte que jamais houve uma época que ao se sentir moderna não se acreditasse por isso mesmo diante de um abismo iminente, acrescentando, como se há de recordar, a passagem é famosa e se refere a Paris, capital do século XIX, que a consciência desesperada (sic) de estar no meio de uma crise é algo crônico na humanidade. Ilusão retrospectiva de quem escrevia no coração do "desespero" europeu dos anos 1930? Seja como for, será preciso periodizar e datar, agora que, feitas todas as ressalvas precedentes, estamos nos aproximando do miolo da pergunta acerca da funcionalidade das crises como paradigma do governo que as controla como quem comanda um espetáculo, que se convencionou àquela altura chamar ainda de política.

A data como sempre é decisiva porque a dúvida a respeito de uma incomum porém crônica sensação de crise enquanto cifra da dominação exercida através do espetáculo (é Debord sim, mencionado de passagem página antes) gira em torno de uma noção, Crise, ela mesma indissociável da ideia correlata, e igualmente envolvendo um coeficiente temporal de realização, de Expectativa, sobre a qual nosso autor de referência no momento está justamente demonstrando que ela vem se esvaziando até o seu grau zero. Noutras palavras, agora nossas, o que ainda de substantivo quer dizer "crise" numa era de indivíduos "sitiados" cercados de situações de emergência por todos os lados? Para bem ou para mal, crises sempre anunciaram alguma coisa. Em regime de urgência o que podem ainda anunciar, caso sejam de fato reais? Esse o ponto, onde mora a dúvida de Lasch. E a nossa, caso tenha cabimento como acho que tem, a saber, dizendo a mesma coisa de outro jeito: recorrer à noção de crise ainda faz alguma diferença agora que nossa relação política com o tempo tornou-se inteiramente outra? Aliás, devolver a noção clássica de crise ao novo clima da história pós-histórica (em pleno Antropoceno a ideia de crise caberia à percepção em prestações da mudança climática em curso, ou seria esta enfim a mãe de todas as crises?), seria talvez o melhor atalho na direção dessa relação alterada entre política e tempo. Assim, num tempo que não cura mais (ao contrario do que acreditavam os filósofos, de Hegel a Sartre), o que poderia ser uma crise cuja acepção clínica pelo menos predominou desde os gregos? Pois então, retomando o fio, passemos à data da tese acerca do controle social pela fabricação de uma sensação crônica de crise e seu cortejo de segredos e mentiras. Estados Unidos, anos 1970. Para muitos, como Fred Halliday, aliás autor da expressão, a década em que se desenrolou a escalada da Segunda Guerra Fria, como sempre travada por procuração entre Estados clientes e aliados, revoluções incluídas, da portuguesa à iraniana, passando pela Nicarágua, segundo Lasch, nunca ficou tão claro como naqueles anos 1970, o quanto aquela sociedade americana era dominada pela 
imagem, sendo o espetáculo culminante daquele período, embora fosse herança dos 1960, a Guerra do Vietnã, e a medida exclusiva do mundo político, uma percepção pública de fabricação profissional, credibilidade e prestígio. Neste cenário não surpreende a audiência das teses de Daniel Boorstin acerca do mundo de pseudo-eventos e quase-informações em que viveriam os americanos, como também não surpreende o prestígio duradouro de Boorstin até hoje entre as várias teorias da conspiração. O próprio Lasch esteve à beira de, embora tenha dedicado um subcapítulo do Mínimo eu à análise do que chamou de recuo estratégico em direção à paranoia na literatura americana da época, Thomas Pynchon em particular, cujos personagens veem complôs por toda a parte, procurando obsessivamente desvendar a real história secreta dos tempos modernos etc. Desde então tornou-se moeda corrente reconhecer naquela literatura (De Lillo, Doctorov, Gore Vidal etc.) o retrato de uma sociedade entendida como uma grande conspiração, e o país uma rede secreta que se confundiria com a ossatura mesma do poder (Perry Anderson). Não era para menos, não só Lasch acompanhara toda a novela do Watergate até a renúncia de Nixon, para ficar no escândalo mais espetacular do período, como devia estar tirando as devidas consequências do mais escabroso de todos os episódios do período, o mencionado vazamento dos Papéis do Pentágono, como lembrado, sete mil páginas de evidência documentária de que durante mais de vinte anos quatro presidentes manipularam e mentiram descaradamente para o distinto público a respeito das guerras da nação e crimes conexos como a famigerada provocação do Golfo de Tonkim (agosto de 1964), pretexto para o ponto de partida de uma guerra full-scale contra o Vietnã do Norte.E por aí vamos, ou melhor, fo- mos. Em suma, a mentira como sistema de Estado. Mais um passo e mergulharíamos nos esquemas mirabolantes da Inside Operation, de Pearl Harbour à Operação Charlie Hebdo, passando pelo 11 de Setembro. Não sei se Lasch embarcaria, mas navega por essas águas ao sugerir a cronificação manipulável das crises. E de qualquer modo, sua citação de passagem sugere que havia lido Guy Debord, mas obviamente não poderia conhecer os Comentários só publicados em 1988, nem mesmo o Prefácio à quarta edição italiana da Sociedade do espetáculo que é de 1979, cuja teoria do "espetacular integrado" por sua vez depende muito da observação da cena italiana dos anos 1970, um mês de maio que durou dez anos. Anos 1970 de novo, uma volta decisiva e irreversível no parafuso. Noves fora a Grande Depressão declarada em 1929, nunca se teorizou tanto sobre a Crise como naqueles anos 1970. Nessa atmosfera sobrecarregada de grandes manobras encobertas, Lasch andou por certo se familiarizando com as elucubrações dos Situacionistas acerca de uma sociedade separada de si mesma pelo Espetáculo, estágio supremo da abstração. Não posso, está claro, me deter no juízo de Debord acerca desse estágio terminal do Espetáculo, quando a nebulosa soviética ("espetacular concentrado") se desmanchava no ar e seu par antitético fordista ("espetacular difuso") principiava a deixar de legitimar-se pela mão única da acumulação, desempregando, desprotegendo e imprimindo dinheiro sem valor. Caracterizado por Debord como o reino do segredo generalizado, domínio do "falso sem réplica" girando à volta de um "perpétuo presente", o "espetáculo integrado", que como todo poder não pode governar sem a mentira, deu o ar de sua graça em estado quimicamente puro no laboratório italiano daquela década, resumo segundo Debord, das contradições 
sociais do mundo inteiro, por assim dizer em queda livre àquela altura. Alguns ingredientes no receituário de uma sociedade movida pelo segredo que domina o mundo e justamente como segredo da dominação numa sociedade formada por espectadores que apenas "olham" para saber o que vem depois: em primeiro lugar, a política "espetacular" do terrorismo, por sua vez emoldurada por uma Santa Aliança entre todos os poderes, o burguês empresarial strictu senso, acrescido de todos os corpos de Estado, e inclusive o poder paralelo da famigerada P2, a burocracia stalinizante do PCI camuflada pelo nevoeiro do "compromisso histórico", a onipresença das organizações mafiosas pela primeira vez operacionalizadas a favor da ordem com desembarque dos Aliados na Sicília, desde então recurso de última instância, como demonstrado pelo vazamento da Operação Gladio com o sequestro e execução de Aldo Moro, outro dos casos tenebrosos a fazer época naquela década de contrarrevolução preventiva sem no entanto nenhuma revolução à vista, salvo o ânimo insurrecional de um jovem proletariado cuja turbulência escapara aos controles partidários de praxe. Era assim tão espessa a névoa da guerra comandada pelo "espetáculo" que os agentes secretos se conduziam como revolucionários e os revolucionários como agentes secretos. E por aí afora no folhetim italiano de Debord, onde o espetáculo falsificava até a crítica social, a começar pela mutação dos antagonismos reais no espetáculo do antagonismo. O folhetim brasileiro de hoje no fundo não é muito diverso, a começar pela banalização do escândalo, a rigor um arcaísmo. Mas voltemos ao laboratório italiano da "estratégia da tensão", cuja iniciativa todos atribuíam a todos, pois foi justamente naquela paisagem nova, em que as populações espectadoras medusadas pelo "terrorismo" engoliam de bom grado todos os demais males menores, que afinal tomou corpo e se formou um novo paradigma de governo, o estado de urgência (em italiano, emergenza), de preferência informal, não declarado nos velhos moldes constitucionais, camuflado no cipoal de uma legislação penal proliferando como metástase. Quem acompanhou no Brasil a novela Cesare Batisti, e seus tenebrosos personagens inquisitoriais, sabe do que estamos falando. Esse o paradoxo inaugural do novo tempo, um tempo de conspirações a favor da ordem existente, em que o essencial permanece secreto, e falsificado ainda por cima. Concepção primitiva da dominação, com intrigas e espiões por toda parte? Anselm Jappe não só acha que não, mas até considera que os anos seguintes multiplicaram as confirmações, e isso dito e publicado muitos anos antes do atual tsunami de vazamentos de todos os tipos de maquinações, até o último gênero high-tech em voga, a "espionagem para o povo" e seus exércitos de hackers, igualmente ativíssimos em matéria de filtragem e interceptação, como aliás se depreende do encontro entre WikiLeaks e Google. Mas não sei se Guy Debord chegaria a saudar o novo Marco Civil da Internet como uma brecha no Espetacular Integrado, sua reabilitação materialista da concepção policial da história não comportava exceções progressitas. Desnecessário recordar que os veteranos da luta política maximalista daquele período não gostaram nem um pouco, para dizer o menos, da versão situacionista daquela indubitável experiência-piloto italiana, que provocou a prisão de milhares de condenados expiando uma guerra civil que afinal não ocorreu, um putschismo tecido com o pano de que são feitos os sonhos, na glosa shakespeariana de Debord. Recuperadas essas peripécias, como ficamos? Pelo menos com uma certidão de nascença: que ao longo 
dos dez anos do Maio italiano, uma "estratégia de tensão" produziu efetivamente uma crônica sensação de crise através da qual "controlou-se" uma sociedade que nem por ser composta de espectadores deixava de estar atravessada por um sem número de lutas, anticapitalistas inclusive, sendo "controle", no caso, uma senha para o seu exato oposto, o reconhecimento tácito da impossibilidade de se governar normalmente, a não ser através da "produção" de uma série de urgências sucessivas. Encerrado o paroxismo do confronto armado, seguiu-se a "normalidade" do novo paradigma, a multiplicação das urgências: urgência antimáfia, anticorrupção, anti-imigração clandestina etc., para alguns veteranos a porta aberta para a escalada de poder da magistratura e sua legislação moral punitiva. Salvo engano, começamos a pisar terreno conhecido.

Todo esse rodeio não me parece inútil para enfim chegar ao nosso ponto: numa era de horizonte rebaixado e expectativas revertidas ao longo daquela década decisiva de colapsos administrados, do padrão dólar-ouro ao boicote de OPEP, qual o poder de esclarecimento e intervenção que ainda teria conservado uma noção como a de Crise, reconfigurada a certa altura de sua evolução semântica e histórica justamente como a expressão de um novo senso do tempo, significando o fim próximo de toda uma época, inclusive intensificando tal processo ao diagnosticar seu estado como crítico? Onde as escolhas entre alternativas fortes e excludentes num lapso de tempo orientado para um desfecho dramático? E no entanto, acabamos de relembrar a propósito do Espetacular Integrado segundo Guy Debord, nunca se falou tanto em crise, e sobretudo operou, como naqueles anos 1970 de contrarrevolução sem revolução, como Marcuse definiu o período que se inaugurava, tanto era assim que até uma nova direita saiu a campo depois de vinte e cinco anos de capitalismo organizado e regulado por considerá-lo à beira da ingovernabilidade, mas multiplicando juízos apocalípticos a respeito de um arranjo até então julgado invulnerável, enquanto no contracampo, Habermas procurava mostrar que a "crise", cujo conceito tratara de reconstruir em novas bases científico-sociais, não era sistêmica mas de legitimação, de qualquer modo pedindo um novo conceito de "racionalidade", sabemos qual. Ao fim daquela década, um artigo que fez data, mais pelo título do que pela argumentação ainda tateante, declarava aberta uma nova crise, a do Futuro (Krystof Pomian). Os anos 1980 correram rápido em direção ao "fim" da União Soviética, deixando pelo caminho vários fins disso e daquilo, uma febre de liquidações batizada Endism em inglês. "Nunca houve tanto fim", são as palavras iniciais de um livro em que aquele colapso apontava também para o campo vencedor e era interpretado como uma "crise" por assim dizer total e especificada como a crise da sociedade do trabalho, crise portanto, e novamente assinalando o fim dramático de uma época. Com perdão da insistência, fica a dúvida: como um conceito de pura expectativa, a noção de crise tal como a conhecemos desde que Rousseau anunciou que nos aproximávamos de um "estado de crises" e do século das revoluções, secularizando uma concepção do mundo como crise (Habermas em 1960, explicando o marxismo como crítica, entre ciência e filosofia), mais adiante inevitavelmente rotinizada à medida em que esse mesmo mundo se "desencantava", inclusive pela recorrência das "crises" numa esfera econômica autonomizada, como um tal conceito pode voltar a "significar" algo em que Presente e Crise parecem formar um bloco só? Não se trata 
de mera elucubração conceitual. Dou um exemplo, colhido naquele mesmo universo do presente perpétuo de um falso sem réplica, segredo generalizado etc, quer dizer no mesmo clima ligeiramente conspiratório em que também respiram as "teorias" de uma ativista como Naomi Klein. Penso, por exemplo, na sua teoria do capitalismo de desastre, cuja ascensão remonta exatamente àqueles anos de virada na concepção do mundo como crise através da multiplicação dos laboratórios para os experimentos de choque, cuja primeira prova transcorreu no Chile de Pinochet, "estados de choque" que descreve como ataques orquestrados, isso mesmo orquestrados, como os imaginava Debord, ataques a fundos públicos em disponibilidade para apropriação direta por ocasião de acontecimentos catastróficos, fossem um golpe de estado ou um tsunami. Nesse quadro, as "crises" e suas ondas de choque são verdadeiros "alvos" de oportunidades. Mas estamos falando de escombros, esse o lastro novo da "crise". Há por certo continuidade no emprego do termo, mas aí tem coisa, uma sucessão de choques não é bem um processo crítico, culminando numa resolução purificadora, para bem ou para mal. Humor negro à parte, até na morte, na qual a sabedoria moderna nunca deixou de reconhecer a maior crise que uma pessoa pode enfrentar, justamente sua revisão como crise carregaria consigo o sentimento de uma passagem, desta para melhor, como no dito popular. A mudança do "clima" da história mudou tudo isso.

\section{NO TEMPO DAS EMERGÊNCIAS*}

Paulo, queria começar por algumas questões que dizem respeito ao estado atual do capitalismo. Em algum momento do livro [O Novo Tempo do Mundo], você usa a expressão "capitalismo informacional" e ironiza, com a observação "seja lá o que isso queira de fato dizer". Supostamente, a expressão designaria um estágio atual do capitalismo, percebido desde o final dos anos 1950 pelo sociólogo Alain Touraine quando ele escreve "A sociedade pós-industrial" para pensar um conjunto de mudanças no modo de produção. A partir da sua referência irônica eu posso pensar que você desdenha de uma divisão em etapas ou fases do capitalismo. Pergunto: faz diferença a crítica ao capitalismo que haja um processo de mudança no modo de produção?

Seria bizarro um livro de ensaios concebidos com o único propósito de identificar o novo tempo de um mundo que já não corre mais pelo mesmo trilho, desdenhar, como você diz, justamente as diferenças, das quais a história nada mais é do que um inventário, na definição bem conhecida de Paul Veyne. E no entanto tampouco haveria história sem o reconhecimento do Mesmo no Outro, para falar como os clássicos. Como os estudos reunidos no livro, no fundo,

*Entrevista a Carla Rodrigues sobre O novo tempo do mundo (Boitempo, 2014), publicada originalmente no caderno "Eu \& fim de semana" do jornal Valor Econômico, em 9 de abril de 2014. 
nada mais são do que capítulos avulsos de uma história intelectual e política de "sucessivos" horizontes de expectativas, não faço outra coisa do que repertoriar e periodizar os momentos de virada, no geral, na direção das coisa novas e ruins, das quais Brecht aconselhava a não se desviar na hora de recomeçar depois de uma grande derrota, ao invés de se refugiar nas boas certezas de sempre.

Se a entendi bem, você está sugerindo que na breve menção ao assim chamado "capitalismo informacional", não segui a risca o conselho. Não sei se seria o caso àquela altura de trocar em miúdos a suposta ironia com que teria desprezado um fato maior do nosso tempo, a centralidade das tecnologias da informação e comunicação nos processos produtivos e as tremendas consequências sociais e políticas desta reviravolta. E dentre as quais há até quem inclua a derrocada da União Soviética, por conta de uma revolução nos assuntos militares decorrente da introdução avassaladora de tais tecnologias. Ou melhor, menos uma introdução do que uma exportação para o conjunto da sociedade de um processo de racionalização tecnocientífica cuja origem é rigorosamente bélica. Por isso nunca é demais o pé atrás quando o capitalismo se renova impulsionado pela guerra de materiais.

Mas não é preciso remontar à origens destrutivas do capitalismo para suspeitar dos termos em que é narrada a marcha libertadora do conhecimento-informação na condição de fonte preponderante, e não exclusiva, do valor econômico. Narrativa reforçada pela visão clean de fábricas sem trabalhadores ou mesmo empresas de transformação sem fábricas. Não é bem assim. Ou pelo menos está mal contada, quando não escamoteada, uma outra história, a da apropriação privada e monopolista de uma criação coletiva da sociedade como o conhecimento.
Não é menos verdade todavia que embora não tenha substituído o trabalho na produção do valor, como a produção da riqueza efetiva depende cada vez menos do tempo de trabalho e cada vez mais do conhecimento como livre produção social, o sequestro deste último pelas relações capitalistas de produção expulsa brutalmente parcelas crescentes dessa mesma sociedade dos circuitos, que outrora chamaríamos de civilizados, de produção e consumo.

Será esta talvez a última e real catástrofe da humanidade. Fugindo, para variar, do trabalho vivo, que sempre considerou um estorvo no seu processo de valorização interminável, o protagonista da guerra social que é a acumulação como um fim em si mesmo, finalmente encontrou uma estratégia de ultrapassagem do mal necessário chamado trabalho. Estratégia que, à sua revelia, pois se trata de um processo cego, empurrou a humanidade sob seu jugo aniquilador - o Progresso, a Modernização, o Desenvolvimento, como se queira - até um limiar que, se transposto, subverteria a relação de valor como mediação social dominante e libertaria enfim a espécie humana da servidão do trabalho e seu cortejo de alienações. Nesse pacote se encontra o dito capitalismo informacional. Com a mão esquerda abre sem querer a porta de saída da pré-história, que no entanto fecha violentamente com a direita, descartando sem maiores états d'âme a humanidade excedente, cujos mínimos vitais são então calibrados conforme sopre o vento da conjuntura, e suas ondas correspondentes, ora mais, ora menos, socialmente punitivas ou punitivamente sociais. Nesse limiar encalhamos, e esperamos em regime de urgência. O presente prolongado desta conjuntura perene - na qual, por isso mesmo, não faltam acontecimentos em cascata em que nada de fato 
acontece, salvo o acontecimento-monstro que todos esperam -, sem ser a única, é a dimensão mais aparente e insistente do Novo Tempo do Mundo.

Nessa mesma linha, eu gostaria de discutir um autor que aparece com frequência no seu livro, o sociólogo Luc Boltansnki, cuja obra O novo espírito do capitalismo tem clara inspiração weberiana. Você acha que é mais produtivo pensar a crítica ao capitalismo a partir da perspectiva de Weber do que da perspectiva de Marx? Em que ponto esses dois autores se tocam e nos tocam hoje na crítica ao capitalismo?

Não aparece tanto assim, pelo contrário. Apenas o suficiente para lançar uma luz retrospectiva sobre a visão luminosa de Walter Benjamin acerca da assombrosa religião que no final das contas o capitalismo vem a ser: um sistema de comandos tão absurdos - tanto para os acumuladores de capital, seus supostos beneficiários, como seus provedores de força de trabalho, impossibilitados de viver fora da subordinação, ambos os extremos acorrentados a um processo sem fim e insaciável - que necessita de um "espírito" que o justifique e que Weber foi buscar na ascese calvinista. Não por acaso numa não menos absurda religião do sofrimento. Observando no seu tempo a metamorfose fascista da ordem liberal, Benjamin notou que o tal espírito enxertado por Weber naquela de máquina moer gente simplesmente evaporara fazia tempo, deixando neste mundo duplamente desencantado uma engrenagem monstruosa puramente ritualística, e como tal, "religiosamente", isto é, escrupulosamente observada.

Se assim foi e voltou a ser, seria preciso corrigir Boltanski e constatar que o "novo espírito" do capitalismo, de espírito justificador não tem absolutamente nada, é pura letra. Aliás, não surpreende que a macroeconomia se resuma a receituários disputando clientes e o discurso econômico, a uma modalidade retórica entre outras. Como também o cumprimento preciso de uma ordem voltou a ser mais importante que o conteúdo das ordens - foi o que a socióloga Silvia Vianna redescobriu observando o comportamento dos voluntários sob contrato que povoam os reality shows, reinterpretados como empresas flexíveis funcionando ao vivo. Daí o estado de alerta permanente em que se vive nesse universo de vozes de comando que se cruzam e se confundem com o ato de obedecer. Agamben chegou à mesma conclusão analisando os dispositivos eletrônicos, aos quais na verdade obedecemos toda vez que lhes damos um comando. O importante é que a obediência assuma a forma de uma ordem que cada um se dá livremente a si mesmo. O ritual da religião capitalista contemporânea se dá precisamente nestas ordens que damos a nós mesmos. E se assim é, o Novo Tempo do Mundo só pode ser um tempo ritual - por exemplo, o ritual securitário das emergências, no qual se reconfigura o poder por excelência de dar ordens e decidir sobre a exceção.

E por falar no diabo, qual o horizonte de expectativa máxima de um brasileiro hoje? Uma Copa do Mundo esperada como o Advento. O sonho da casa própria, que é um sonho real e diurno, desenrola-se no raso desesperador da sobrevivência. Contra o pano de fundo desse deserto, o Grande Jogo prestes a acontecer é o arremedo da vez da transcendência. Com a regularidade com que retornam no calendário presentista do Novo Tempo do Mundo, os megaeventos são rituais de massa, e como tal, um tremendo dispositivo de governo, algo como um não menos tremendo centro emissor de comandos pacifica- 
dores, pois é preciso que durante a Copa a paz seja total até os ambulantes serão vacinados. Um ritual da religião capitalista como o megaevento em questão traz consigo o seu próprio acidente específico - como os demais aparatos tecnológicos, trem de alta velocidade, avião supersônico, usina nuclear etc. No caso de um acontecimento fabricado como uma tecnologia de controle já não é mais possível distinguir acidente de atentado ou sabotagem, por isso o megaevento da hora sempre retorna como um tempo de emergência. Cada arena, uma situação de sítio. Cada sede, um zoneamento de ocupação militar. E quando o megaevento se for, tudo isso ficará na praia à espera da próxima maré, repetindo-se religiosamente os mesmos rituais de segurança, um ponto zero acima. Se há um real legado da Copa, é justamente o da atualização acelerada dos aparatos de vigilância e repressão, com inteligência é claro, para atender a uma eterna demanda progressista dos sociais-punitivos.

A crítica ao capitalismo se relaciona diretamente, pelo menos na minha leitura, com o título do seu livro: o novo tempo do mundo. Há, se seguirmos a sua referência a David Harvey, uma ênfase no just in time, na verticalidade, há um novo tempo opressor, sem futuro. Mas o título também dá ao leitor a chance de ser otimista. Um novo tempo do mundo - novo, aqui, como algo que renova as esperanças de mudança. O que é para você o novo tempo do mundo?

É a primeira vez que alguém vislumbra uma nota positiva no que digo ou escrevo. Quem sabe se a sua boa impressão de que há ainda uma chance oferecida ao leitor de ser otimista, como você diz tão bem, não deriva da sensação de que afinal estamos mesmo atinando com as coisas novas e ruins que nos levaram às cordas. Pois o limiar onde atolamos e apodrecemos, de colapso em colapso, quanto mais as forças produtivas se desenvolvem, juntamente com os estados de violência próprios do governo da emergência, não deixa de ser justamente isto mesmo, um limiar. A mutação que rebateu as grandes expectativas modernas sobre as urgência do presente não é necessariamente uma má notícia, ela é, pelo contrário, uma espantosa novidade depois de dois séculos de espera, desde que a encaremos como tal, nos seus próprios termos. E para isso é preciso uma faxina em regra do nosso repertório, a começar pelo intragável jargão progressista-participativo, que é o discurso do poder que simula ainda estar conduzindo sociedades orientadas para o futuro. Política numa era de expectativas decrescentes só pode ser gestionária e policial. Quando "o futuro se aproxima do presente explosivamente carregado de negações", o capitalismo do desastre como oportunidade de acumulação apenas multiplica os regimes de segurança dispostos à beira do abismo, ainda que compulsivamente, pois assim o exige a lógica da valorização, estenda indefinidamente a fronteira autodestrutiva da predação. Emparedados nesse limiar, carecemos é de uma antipolítica que saiba decifrar o renascimento paradoxal de expectativas que se abram para outras dimensões temporais. Se uma esquerda sem futuro ainda tem futuro, devemos procurá-lo noutra parte.

Falar em tempo é também falar em história. Você refuta a hipótese de fim da história, tão presente nos discursos triunfalistas da sociedade liberal de livre mercado. Mas você também é um duro crítico de tudo que poderia ser englobado numa categoria "solidarie- 
dade", para não usar uma palaura mais antiga, assistencialismo, as boas consciências agindo em prol e em nome dos direitos humanos. Você acha que direitos humanos só podem ser pensados dentro do registro do liberalismo?

Dou um exemplo. Penso na repolitização do novo tempo jurídico que está fazendo ressurgir o passado no presente. Diante de um passado abominável de violações, o tempo já não cura mais, como se pensava e legislava quando o progresso visto de longe sorria, embora de perto sempre arreganhasse os dentes. Entramos não faz muito no domínio do imprescritível e do efeito retroativo autorizado. $\mathrm{Mu}$ dou a relação do dano com o tempo. Sendo um imperativo do dever de memória, é possível dizer, e já foi dito por um teórico da Justiça de Transição, que a necessidade cada vez mais incontornável (por que?) de um acerto de contas com o passado acabou fazendo com que a esquerda buscasse alcançar seus objetivos clássicos de justiça e emancipação por meio do foco na reparação do horrores do passado. A seu ver, essa ampla disseminação de demandas por reparação de malfeitos do passado não só revela um inequívoco declínio das políticas explicitamente orientadas para o futuro, como confirma que a busca do futuro no passado mudou completamente a maneira como pensamos e falamos sobre política. O presente prolongado de hoje é assim uma sociedade da responsabilização expandida até os confins do passado mais remoto, para escândalo dos historiadores chocados com a atual inflação de anacronismos toda vez que são convocados na condição de peritos forenses, e justamente historiadores de um presente a perder de vista. Essa uma das dimensões do Novo Tempo do Mundo. E não reclamam só do anacronismo. Na visão deles, a memória da Shoah substituiu a do antifascismo, e no processo, a do Gulag apagou a das revoluções, como se a lembrança das vítimas não pudesse conviver com a das suas lutas, conquistas e derrotas. Então ficamos assim. Essa nova temporalidade política se bifurca. Capturada no andar superior pelo progressismo governamentalizado, tornou-se o receptáculo de políticas públicas de administração de danos, sendo que a reparação é sempre uma intervenção que apenas restaura para melhor corrigir uma disfunção, por mais que a elaboração final do trauma signifique uma libertação sem a qual ninguém vive. Chegamos assim à situação surreal de um Estado a um só tempo violador e reparador, que melhora seus indicadores de IDH enquanto segue chacinando. A menos que seja assim mesmo, numa sociedade que a Ditadura moldou. Não estou censurando nada nem ninguém apenas constatando mais uma reviravolta em nosso regime de esperas. Um jovem pesquisador lembrou recentemente que quem emplacou a ideia de anistia como esquecimento foi sobretudo a esquerda, que se preparava para retomar a luta progressista de antes contra uma ditadura ela mesma também modernizadora. Estávamos então no mesmo barco do antigo tempo do mundo. Sobreveio um tranco sistêmico e global que nos roubou o chão. E com ele o dever de memória foi aos poucos se convertendo num imperativo, hoje oficial. Mas onde corre um risco menor de se tornar oficial, no chão da fábrica social, a percepção característica do limiar no qual ingressamos, de que meio século depois as atrocidades que inauguraram o novo tempo brasileiro parecem ter acontecido horas atrás - ao passo que as barbaridades perpetradas ao longo do Estado Novo, por exemplo, uma ditadura em tudo precursora do que veio depois, também para nos civilizar e livrar do 
comunismo, foram engolidas sem maiores sobressaltos como um ponto histórico facultativo -, pode muito bem estar abrindo caminho para a antipolítica de que há pouco falávamos. A catástrofe que hoje reúne todos os dias vivos e mortos, canalizou para o rio da memória ativa um horizonte de expectativas insatisfeitas que justamente não brotam mais de um arquivo morto, como se só pudéssemos avançar olhando para trás, sem ódio nem remorso.

O ultimo ensaio é uma grande leitura das manifestações de junho do ano passado, uma bricolagem de referências livres, no qual me parece que você toma como fio condutor a palaura insurgência e suas múltiplas funções nos discursos. Há quem tenha chamado de revoltas, há quem mantenha o termo manifestações, como um acontecimento datado. O que você acha que se perde e que se ganha com "insurgência"?

Você também deveria fazer a pergunta ao diplomata norte-americano cujo olho clínico enxergou no Programa de Pacificação das Favelas o que os manuais da contrainsurgência contemporânea remendam e seu país aplica um pouco por toda a parte no mundo: trabalho social com armas. Ele não hesitaria muito na resposta: no Sul Global, desenvolvimento social é antes de tudo uma tecnologia de segurança e, assim sendo, contrainsurgência e desenvolvimento são uma só e mesma coisa. Acho que o Eduardo Tomazine, que rastreou o tópico, batizando-o de Doutrina da Pacificação, acrescentaria que a novidade na parte que nos cabe nessa guerra sem fim é que o inimigo foi internalizado. E isto não é pouca coisa, como se pode verificar quando o Manual de Garantia da Lei e da Ordem, baixado pelo Ministério da Defesa, tipificou como "for- ças oponentes" os manifestantes de junho. Poucos meses antes, os pacificadores cariocas de carteirinha já haviam feito o mesmo amálgama na construção do novo inimigo. De minha parte, pude apenas observar que a ideia fixa da Pacificação - uma obsessão nacional, dede os massacres da Regência, que a canonização de Caxias sublimou - tem a mesma idade política da Transição. Ajuda a compreender porque vivemos hoje uma "guerra ao contrário", como eles mesmos diziam quando descobriram que o Rio descivilizava-se. Sei que a palavra insurgência é esdrúxula, a ponto de incluir os coxinhas entre os sublevados. Outra novidade do período. O Golpe de 64 deslanchou uma contrarrevolução onde não havia revolução. A potência emergente que voltou a associar desenvolvimento e segurança pode muito estar se instalando, sempre preventivamente, é claro, numa situação de perene contrainsurgência sem insurgência. Só por isso a palavra já interessava. 


\section{EXAUST T̃̃o*}

(Resposta a mais uma pergunta sobre a crise)

Crise econômica, ameaça de grande regressão nos direitos sociais e crise política são notórios no Brasil hoje. Vivemos uma crise de governo, uma crise da democracia, o fim de um ciclo? Como você enxerga a atual conjuntura do país?

Vivemos o fim de um ciclo. Mas não um ciclo qualquer, tampouco uma crise cíclica, como é da natureza de um sistema descrito por Marx como a contradição em processo. Estamos simplesmente vivendo o fim de toda uma era. Há quem veja nesse desfecho, que se arrasta aos trancos e barrancos desde junho de 2013, talvez a mais grave crise de nossa história. Por isso mesmo não é de fácil identificação. Não é uma crise saneadora a mais, ao fim da qual o bom negócio chamado Brasil entraria nos eixos. O drama agora é outro. E olhe que a recessão econômica mal está começando, o desemprego ainda não bateu forte, a polarização está muito longe dos padrões venezuelanos ou mesmo argentinos, para ficarmos nos ingredientes clássicos, dentre os quais nem precisei mencionar um ainda muito remoto

* Entrevista ao Correio da Cidadania, que acabou se transformando em um quase artigo, publicado em 17 de julho de 2015, sob o título de "A fórmula mágica da paz social se esgotou". 
surto inflacionário. No entanto, semana sim semana não, a remoção institucional da presidente entra na agenda, na dependência de um arranjo entre os caciques de sempre, enquanto a esquerda legal se limita a soltar manifestos. Creio que dá para sentir o drama e sua novidade nessa trivialização da conversa sobre as modalidades de cassação de um mandato popular, em meio à gesticulação de uma esquerda que na melhor das hipóteses já é apenas memória e comentário.

Esse o meu ponto. Nunca se falou tanto de uma crise, e no momento mesmo em que ela transcorre, como se já fosse passado passando, por assim dizer. Então: não sei se é mera impressão mas, para ser sincero, acho que ninguém aguenta mais falar justamente da mais grave crise de nossa história! Menos ainda ouvir ou ler a respeito. Estamos todos à bout de soufle. Não por acaso se falou muito do fôlego curto dos manifestantes de Junho. Desconfio que não sou o único a ter chegado a esse ponto de saturação. Mesmo assim, sabendo de antemão que mal serei lido, pois todo mundo já disse de tudo ao longo desses seis meses de ata-não-desata, vou procurar responder à pergunta. E precisamente puxando por esse fio a meu ver revelador da sua natureza profunda, só aparentemente frívolo: estamos cansando de tanto falar da crise, no fundo estamos sendo vencidos pelo cansaço.

Ouvi certa vez um especialista dizer que a Revolução dos Cravos batera no teto e refluíra até se extinguir, para além dos obstáculos mais ou menos previsíveis, como o veto da OTAN, a desmoralização soviética ou o dinheiro da União Europeia, porque o povo português simplesmente cansara da batalha diária nas ruas durante meses a fio. O fôlego simplesmente acabara. Exatos quarenta anos depois, não é menos verdade que neste último dia 5 de julho não se sabe bem onde $60 \%$ dos eleitores gregos foram buscar a energia que faltava para derrotar, por enquanto nas urnas, o regime de austeridade imposto pelo atual sistema europeu de poder sobre a moeda comum, numa palavra, venceram o cansaço provocado por cinco anos de um arrocho que parecia sem fim e ainda não se sabe que destino terá. Nos dois contextos de crise, uma revolucionária, outra de restauração da ordem, o cansaço pode muito bem se apresentar como uma chave política capaz de fechar ou abrir uma conjuntura que está longe de ser apenas mental. Quanto a nós, está claro que não chegamos ao fim de nenhum capítulo da mítica Revolução Brasileira da minha geração, era só o que faltava, embora não seja menos impressionante a sensação incongruente de estarmos nos defrontando com uma contrarrevolução que não veio para liquidar ou prevenir revolução alguma, ou mesmo as tais “conquistas sociais" que não ameaçavam ninguém, antes contribuíam para o desarmamento moral da nação, muito embora o pau continuasse comendo solto nos porões da Democracia, mas a um fim certamente chegamos, e além do mais exaustos. Pois então é esse um dos sintomas desconcertantes dessa anomalia com cara de crise à moda antiga. A inexpressiva vitória eleitoral do ano passado, à base de voto no mal menor e correria esquerdista de última hora, revelou uma sociedade cansada e soterrada por uma avalanche conservadora que de geração espontânea não tinha nada, crescera nos anos das tais conquistas.

Durante a Ditadura, o que mais se debatia nos círculos oposicionistas era a natureza do "modelo", como se passou a falar desde então. Qual a natureza do modelo econômico ou do modelo político do regime, quais os seus limites, em função dos quais, cedo ou tarde, se esgotariam caso não se renovassem. Esse então o momento da crise, e portanto 
o momento ótimo para a virada que ela representava segundo a acepção clássica do termo. E ela finalmente veio com as crises conjugadas da dívida, da inflação, do petróleo etc. Todas interpretadas como choques, a um tempo externos e internos. Como também passaram a ser de choque as terapias adotadas para reverter a fase aguda da crise. Como um teórico observou recentemente, cada época tem as suas doenças paradigmáticas, assim tanto a Guerra Fria como o Terror Branco das ditaduras do Cone Sul seguiram o esquema imunológico, na verdade um autêntico dispositivo militar de ataque e defesa orientado pelo princípio de eliminação de tudo o que fosse estranho, mesmo que desprovido de qualquer intenção adversa, bastava a estranheza enquanto tal. Todo o repertório punitivo de hoje em torno de choque disso ou aquilo, ordem, gestão, ou mesmo capitalismo, como disse um sábio no fim dos anos Sarney, é resíduo arcaico daquele período idem. O Choque está nas ruas desde Junho mas os assim chamados golpistas (outra reminiscência) estão tratando a corrupção endêmica como uma falha imunológica generalizada, como nos tempos em que subversão e corrupção eram intercambiáveis. Não há mais campanha de vacinação contra o vírus comunista, por mais que alguns homens das cavernas espumem. O estresse agora é outro, ou melhor, só agora o paradigma do estresse tornou-se lugar comum, estendendo-se da saúde estourada no trabalho ao colapso dos ecossistemas.

Mas voltemos ao tempo em que os modelos entravam em crise e se esgotavam. Para reparar que talvez (ou melhor, com certeza) não seja mais assim, sendo a crise um nome antigo para uma coisa nova. Seja como for, por inércia, ou clarividência que ainda não encontrou a palavra da vez, de esgotamento é o que mais se fala, seja das virtu- des terapêuticas do lulismo, seja de políticas específicas, a começar pela exótica nova matriz econômica. Sendo a novidade o esgotamento simultâneo, reforçando-se mutuamente, de vários mecanismos de governo, das coisas e das populações, para prolongar a velha distinção de Saint Simon da qual a tradição de esquerda não soube se desvencilhar. A esta altura, desnecessário enumerar as múltiplas falências, do manejo macroeconômico ao distributivismo indolor. Tudo bateu no limite, pelo que se lê nas centenas de comentários. Tampouco vale qualquer comentário o circo de horrores político. Salvo pela paródia grotesca da antiga equação keynesiana do bom governo que induzia cada classe a assumir o papel da outra, de tal modo que o capitalismo no centro parecia um jogo de soma positiva. Por aqui o que vemos são centrais sindicais fechando com os megaprojetos tocados pelas empreiteiras chocadas pela Ditadura enquanto as pavorosas bancadas da bala, da bíblia e do boi jogam cascas de banana nas políticas de direita de um Executivo de esquerda. Mas chega de varejo e conjuntura, o que não falta é colunista em cima dessa rapadura.

Para voltar então ao nosso "esgotamento" de tudo e ao mesmo tempo, é bom não perder de vista o timing nada trivial do encadeamento dos diversos estresses (para variar) hídricos das grandes regiões metropolitanas, aos quais se soma a iminência de outros tantos apagões. $\mathrm{Na}$ mesma linha, um governo em queda livre um dia depois de sua posse, não deixa de ser no seu gênero um evento extremo. Se estivéssemos à procura de uma metáfora que resumisse todo esse clima de consumação de uma época, nada melhor do que o olho clínico de um personagem carismático no seu ocaso. É no "volume morto" que nos encontramos mesmo, em todos os sentidos abaixo da linha 
de captação do que quer que seja, esgotamos por predação extrativista um imenso reservatório de energia política e social armazenada ao longo de todo o processo de saída da Ditadura. A entropia avassaladora de agora não afeta apenas os últimos doze anos e meio de hegemonia lulista como se costuma resumir o polo prevalecente nesse período de FlaFlu eleitoral ininterrupto, mas o longo prazo iniciado por uma Transição que está morrendo agora na praia. Os pretensos herdeiros desse espólio simplesmente não sabem o que os espera ao apressar seu fim institucional. Estarão abreviando sua própria sobrevida, pois a fuga para frente que ainda insistimos em chamar de crise é antes de tudo um processo ao qual nenhum lance dramático porá fim, nem suicídio, quanto mais intrigas regimentais de políticos e negocistas de quinta. Vencidos pelo cansaço então também é isso: trinta e cinco anos ralando, e de permeio um descomunal desperdício, o emblema mesmo da tragédia segundo os Antigos.

A crise é assim essa convergência desastrosa de uma inédita exaustão de todo tipo de recursos, dos mais elementares aos mais elevados, da polinização à imaginação política. Até a potência de Junho parece que se esgotou. Pois é tal a entropia do capitalismo, desorganizado desde o Big Bang de meados dos anos 1970 em seu núcleo orgânico, que desorganiza até mesmo as forças antissistêmicas. Só para efeito de comparação, veja-se o caso do outrora maior partido de esquerda do Ocidente. O PT não está agonizando por força de rejeição imunológica, por maior que seja o efeito do choque externo das ondas sucessivas de anticorpos enraivecidos até o ódio mortal, mas por motivo de uma combustão interna que o consumiu por assim dizer do berço ao túmulo. Nenhum ato de violência de classe o desviou de sua vocação original, pura e simplesmente dissipou-se a energia que o mantinha em funcionamento. Bem como a das grandes centrais sindicais e movimentos sociais históricos que gravitavam em sua órbita. Foram todos vencidos pelo cansaço, como sabe todo batalhador de movimento social, quase sempre à beira de um burnout. Dito assim, parece quando muito a expansão duvidosa de uma metáfora mas apenas porque esquecemos que o PT nasceu antes de tudo de um colapso, mais precisamente do colapso da construção da sociedade do trabalho no Brasil, justamente, mas agora em plano global, pois estamos falando de modernização capitalista, por uma falha do "motor humano" de todo o edifício. Como não posso me explicar, corto o caminho por uma recapitulação de época, afinal estamos tentando desde o início identificar o fim de uma época e não a enésima alternância de ciclo e crise.

Como lembrado, o raio detonador da crise caiu em junho de 2013. Em março daquele ano, a aprovação do governo beirava níveis norte-coreanos. Três meses depois, se ainda não estava no chão como agora, rolava ladeira abaixo. Por isso ganhou mal as eleições, ao contrário da direita que perdera convencida de que o seu ressentimento já era uma praga nacional. Outro recurso que se esgotou e marquetagem alguma renovaria. Para uma comunidade política de expectativas imaginadas como a brasileira, e como tal embalada desde o berço por uma procissão de milagres e miragens, uma reversão traumática. Em menos de quinze dias de ação direta nas ruas, e outros tantos de uma insurgência coxinha jamais vista, embora estivesse a rigor na cara a tremenda sociedade aquisitiva-conservadora que o elixir lulista irrigara, virou letra morta a grande narrativa contemporânea do Brasil global player que deu certo e rendia conforto e boa consciência à recaída neodesenvolvimentista da esquerda, literalmente um projeto amazônico de po- 
der para escola superior de guerra nenhuma botar defeito. Mas deixemos de lado por enquanto nossa Segunda Guerra Fria, parcialmente imaginária como a primeira, embora quentíssima na periferia, também como a outra. Numa palavra, a fórmula mágica da paz simplesmente se esgotou como todos os demais recursos que alimentaram o jogo de cena da trégua lulista. Todo mundo sabe de traz para frente quais eram esses recursos: o consenso das commodities, o acesso facilitado ao crédito e consequente endividamento popular em grande escala, o consumo de massa puxado por uma descomunal e caótica expansão urbana etc. Como também todo mundo sabe igualmente que nada disso teria sido possível caso o monstruoso renascimento do poder de mercado chinês não tivesse subvertido todo o metabolismo do capitalismo global, tanto pela reconfiguração da divisão internacional do trabalho, como da divisão internacional da natureza, Amazônia incluída. Como resumiu Camila Moreno, "nós estamos dentro da China, e a China está dentro de nós." Um dia ainda nos daremos conta de que o drama de época que está se encerrando agora representou-se em dois palcos distintos, transitando do finado Consenso (financeiro) de Washington ao não menos fantasmagórico Consenso (extrativista) de Pequim. Mas não estou querendo resumir toda essa época dizendo que o cobertor encurtou, o armistício rompeu-se e a guerra social voltou, pois ela nunca foi embora, nossa “pacificação”, como as aspas de rigor indicam, nunca deixou de ser crescentemente armada, a quarta população carcerária do mundo não é apenas uma enormidade estatística, mas uma política de sequestro de populações selecionadas para apodrecer.

O que portanto está virando pó, ou definitivamente já virou, não era em absoluto um horizonte em expansão, mas antes de brutal contração, ofuscada no entanto pela poeira de uma ditadura que batia em retirada. Nem por isso aquela narrativa ascensional, segundo a qual uma nação reencontrara o seu destino, deixando para traz um ciclo autoritário, constitucionalizando a nova ordem, contendo a hiperinflação e estabilizando a moeda para em seguida incluir os pobres num mercado interno de consumo de massa, desenhar políticas sociais celebradas mundo afora como best practices, projetar suas próprias transnacionais, arrastando consigo megacanteiros de obras de infraestrutura e muitos outros eteceteras, todos igualmente milagrosos, pois sem ônus para qualquer interesse estabelecido. Nada nessa narrativa de redenção que acabou rendendo capa na Economist era inteiramente falso, pela simples razão de que poderia ter sido muito pior. Como mal menor não é progresso mas estabilização numa desgraça de qualquer modo incontornável, como de resto sabem todos os envolvidos no conflito Israel-Palestina, para dar um exemplo extremo porém congruente, um impasse que um insuspeito historiador do problema dos refugiados palestinos, Beny Morris, chamou de apocalíptico. A verdade verdadeira em nosso caso de sucesso, a caminho, de sucesso em sucesso, do esgotamento de agora, consistia, ao fim e ao cabo, no êxito na contenção de um processo de desintegração múltipla que exigia um novo tipo de governo na contramão da rigidez disciplinar do desenvolvimentismo de caserna.

O horizonte de expectativas tão brutalmente rebaixado de Junho para cá tinha na realidade um perfil baixo desde o início, o fato é que lá atrás recomeçamos por baixo, com uma democracia de baixa intensidade (novamente "racionada", como diria Marighella e relembrou recentemente Lincoln Secco), acoplada a um processo de desestruturação produtiva altamente explosivo que da 
noite para o dia descartou por falta de interesse econômico uma massa considerável de futuros trabalhadores inviáveis, salvo para o subemprego nos mercados informais ou ilícitos. O sopro novo conquistado no processo de saída da Ditadura, sem ser de modo algum efeito de uma respiração artificial, foi se esgotando desde então à medida em que uma queda social jamais vista exigia uma política "presentista" de pronto atendimento, igualmente inédita em termos de engenharia social. Resumindo de outro modo: à constatação silenciosa de que a construção de uma sociedade do trabalho no Brasil era página virada, respondeu-se com a invenção (aliás bipartidária) de um novo governo do social, cuja fratura a eclipse do trabalho selara. Como no seu país de origem, a França, estava fora de cogitação uma sociedade salarial no Brasil. Porém, o mais desconcertante naquela saída em falso, na qual somente mais tarde reconheceríamos o que ela era, a rigor uma saída de emergência, é que com ela se abria uma outra frente de trabalho. Entendamo-nos. Por assim dizer, o que se deteriorava por um lado brotava do outro: uma onda nunca vista de trabalho social militante parecia varrer o país, que passava a ser visto como um imenso mutirão de resgate de uma dívida social histórica que a Ditadura agravara ainda mais. Tudo se passava então como se o choque causado pela crise da dívida, que explodiria na moratória de 1987, tivesse intensificado por sua vez uma certa percepção social de emergências acumuladas, como se o flagelo da hiperinflação, a fome velha e nova, a demanda por direitos achados na rua, a dívida externa impagável que ninguém contraíra etc. etc. formassem um grande continuum de urgências pedindo outras tantas intervenções. O take off celebrado mais à frente, quando moeda estável e inclusão através dessa mesma moeda formaram outro continuum, decolaria justamente desse campo humanitário minado.

Sob o signo da carência sem fim, aos poucos a política deixava de ser vista como luta para se converter em ação terapêutica voluntária. Até mesmo o ciclo de acumulação primitiva e seu cortejo de violências saneadores representada pela onda de privatizações e âncoras cambiais também não deixou de ser uma fuga para frente e como tal uma outra ilusão encobridora de nossa queda. A dominância financeira que se consolidou a seguir amarrou de vez nosso capitalismo de cupinchas (nossa versão do crony capitalism inventado no sudeste asiático), do qual o Estado, paradoxalmente ampliado pelas privatizações, tornou-se o nó de todos os nós de toda aquela rede de big shots consorciados.

Empurrada pelo trabalho social de inclusão - em suas várias vertentes: estatal, empresarial, Terceiro Setor, igrejas, e operadores dos mercados de substâncias ilícitas - pode-se dizer que a monetização integral do laço social era uma questão de tempo... e dinheiro. A começar pela redenção em dinheiro vivo justamente daqueles sujeitos monetários sem dinheiro deixados pelo caminho pela marcha de nosso crescimento oco pós-colapso. Mas é claro que não vou reabrir agora o dossiê das Transferências Monetárias Condicionadas, o Welfare do século XXI, segundo Lena Lavinas. Um modelo (isso mesmo, mais um modelo) cujos recursos (em todos os sentidos, mágicos inclusive) estão precisamente, não custa repetir, se esgotando (também em todos os sentidos), por incrível que pareça, ou melhor, não, faz todo o sentido, política social como colateral de acesso ao sistema financeiro de forma a potencializar o consumo represado por pobreza e salários historicamente baixos. O fato é que batalhando por, e em 
nome de, emancipação, alargávamos uma espécie bizarra de Câmaras de Compensação e Reparações onde cabia todo tipo de acertos de contas: novamente um continuum no qual se expressa uma outra relação da política com o tempo, uma tremenda novidade em sociedades nacionais que se formaram orientadas para o futuro, de acertos seja com as contas de um passado de abandono ao deus dará social, seja com um passado de grandes violações de direitos humanos em que a reparação monetária passa a entrar sim em linha de conta, como se os crimes da história se pagassem agora com dinheiro (note-se de passagem que a história deixou de ser uma estrela guia), ou ainda na forma de ajustes pontuais a título de redução de danos, e mais uma montanha de eteceteras na mesma linha da política de ambulância e governos terceirizados. Uma sociedade cansada de gestão e agora em crise dessa mesmo gestão é isso, intervenções para enxugar gelo e retardar um pouco um processo entrópico maior. No limite, uma sociedade em que até trabalhar pela própria emancipação parece cansar mais do que se deixar sucumbir de uma vez pela intensificação alucinada desse mesmo trabalho que ninguém consegue encontrar.

Viajando? Pois então voltemos aos trilhos. Não é mero acaso que toda a engrenagem da transição para um pretenso capitalismo descarbonizado (e mais ou menos como num processo dito de Justiça de Transição) esteja baseada precisamente num mercado de compensações no qual se compra o direito ao mal menor das emissões excedentes, tal como o dano colateral num ataque de Drone desincumbindo-se de sua kill list entra na conta de uma prevenção humanitária maior (um massacre de turistas numa praia mediterrânea qualquer). Tudo se compensa, além do mais, e cada vez mais, monetariamente, neste cenário de desgraças comparadas, sob o fundo do qual falar no avanço de nossas conquistas sociais que a "crise" estaria estancando, não digo que beira o escárnio por ser simples falta de noção, embora sempre se possa dizer: antes isso do que nada. Mas é justamente essa visão progressista do progresso por degraus de melhoria a subir ou a descer que caducou. E esvaziou-se precisamente tal lógica ascensional escandindo o curso do mundo quando se passou enfim a convocar como último recurso (novamente) o direito dos pobres ao dinheiro, se não estou abusando do esforço esclarecedor do filósofo Homero Santiago de pensar os efeitos paradoxais do Bolsa Família. Entretanto, vai na direção contrária, embora raciocine a bem dizer nos mesmos termos, a figuração da segmentação dos pobres nas periferias segundo o sociólogo Gabriel Feltran, cenário sombrio onde se aposta pesado no dinheiro como única mediação do conflito entre grupos que de outro modo se confrontariam em condições de alteridade radical e violenta: sejam legais ou ilegais os mercados onde circula livremente o pagamento à vista em efetivo, o dinheiro é a última fronteira do "comum".

Como é o último recurso mesmo, quando também ele começar a secar na chapa quente de um outro aquecimento global, o regime de espoliação punitiva que é o Estado de Austeridade, voltaremos a rolar ladeira abaixo depois da insustentável pausa conservadora das anti-reformas ou não-reformas lulistas (urbana, agrária, tributária etc.). Para se ter uma ideia dessa ladeira e dos sucessivos horizontes que por ela vão se estreitando desde que caímos para cima, como diziam os humoristas nos tempos da descompressão política com inflação nas nuvens, basta lembrar que houve época em que o assalariamento e a correspondente subordinação ao comando do capital pa- 
recia aos despossuídos e estropiados em geral a única rota de fuga aos horrores do mando proprietário num país de raízes coloniais. E para alguns, selecionados a dedo pela máquina varguista da "cidadania regulada", na fórmula famosa de Wanderley Guilherme, uma estreita porta de acesso ao mundo dos direitos básicos do eleitor-trabalhador. Agora que o assalariamento se dessocializou, pulverizando a classe, o acesso ao dinheiro nu e cru se apresentou como a tábua de salvação da vez. Qual será a próxima em nossa Câmara de Compensações, cujo fornecimento de oxigênio a atual geopolítica de recursos escassos está cortando?

Para que não haja mesmo dúvida a respeito do que vem por aí, relembro que um coletivo carioca, agrupado teórica e politicamente em torno da Crítica do Valor, há algum tempo vem refinando suas análises acerca do que denominam "gestão da barbárie", sobre a qual se explicam e ilustram, por exemplo, no livro Até o último homem, a respeito da gestão armada da vida social na cidade olímpica do Rio de Janeiro. Foi precisamente essa gestão da barbárie que se esgotou com a crise exposta pela reviravolta de Junho, esquerda e direita confundidas na mesma ressaca, e que evoquei nesta digressão sobre a crise de exaustão numa sociedade cansada. Sai a gestão, resta a barbárie. Como tal gestão e o fabuloso arranjo lulista são uma só e mesma coisa, pode-se dizer que deixará saudades, seja dito em agradecimento e louvor à esquerda que está sendo escorraçada agora na ignomínia. Alguém lembrou com justeza que o ônus será coletivo. Iremos todos pedalar no inferno por uma geração, na melhor das hipóteses.

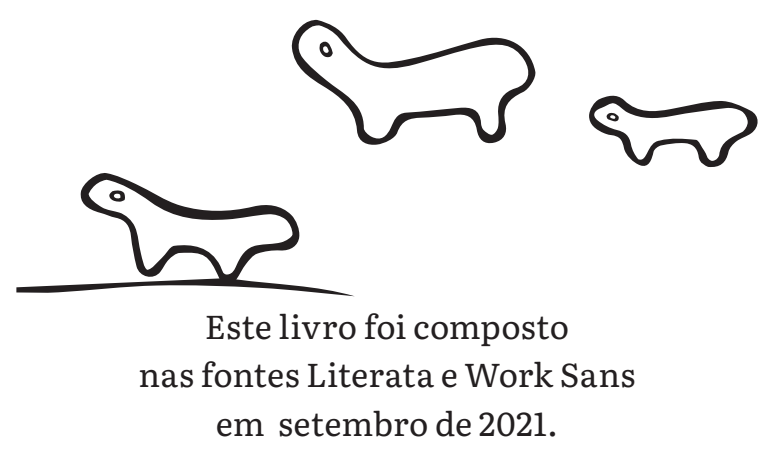

